\title{
الفتح على أبي الفتح تحقيق د/ رضا رجب
}

\section{دكتور/ عبدالاله بن صالع الفلاح"}

\section{المقدمة}

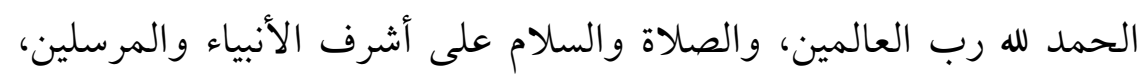

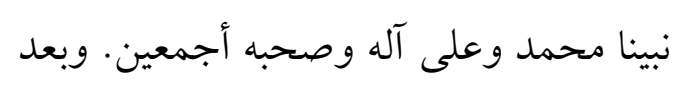

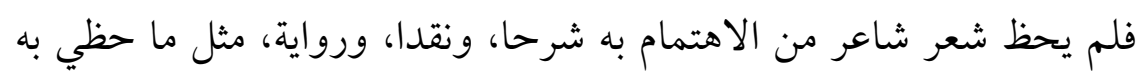

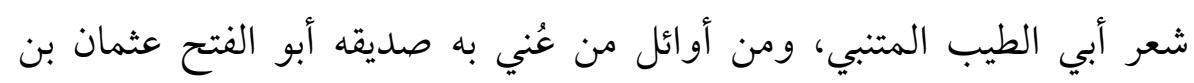

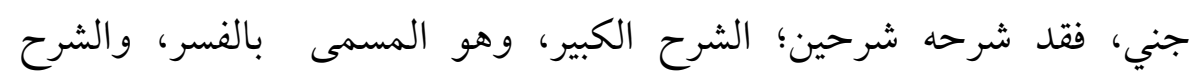

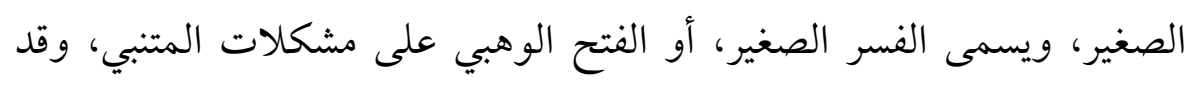

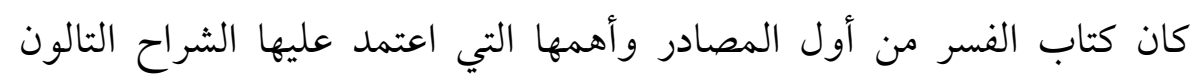

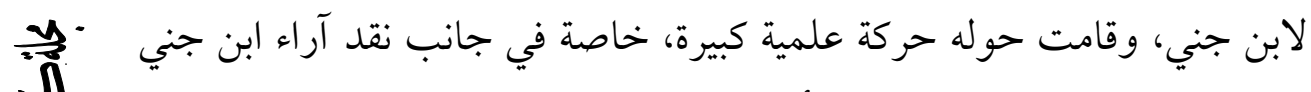

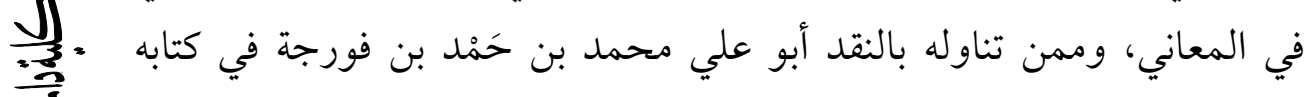

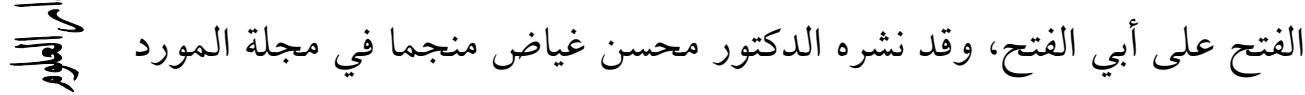

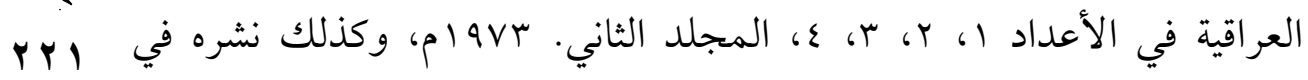

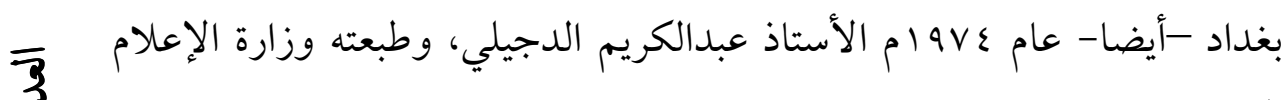
العراقية.

لكن تلك النشرتين لا تليقان بكتاب نفيس مثل هذا الكتاب، فكلتا النشرتين

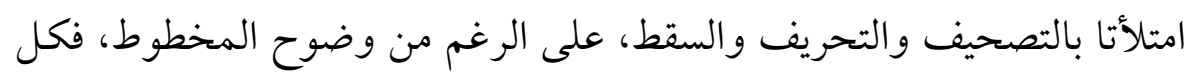

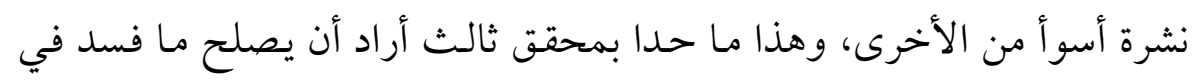

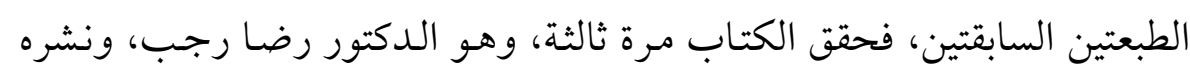

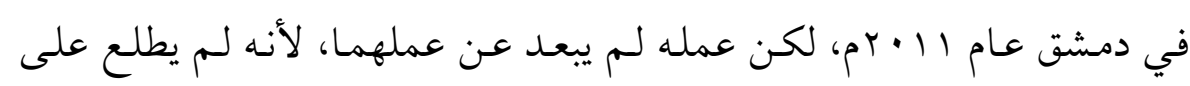

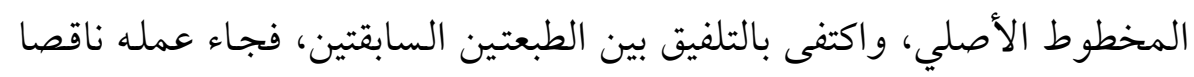

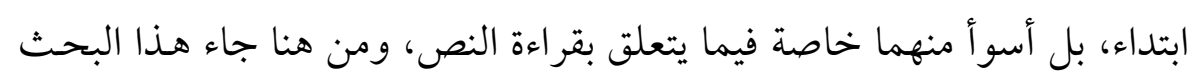


الذي تناولت فيه بالنقد طبعة الدكتور رضا رجب، لأنها آخر طبعة للكتاب، وقد

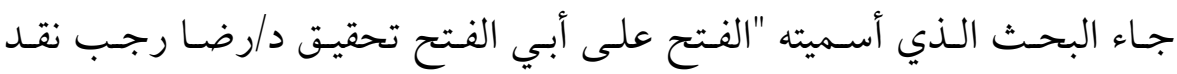

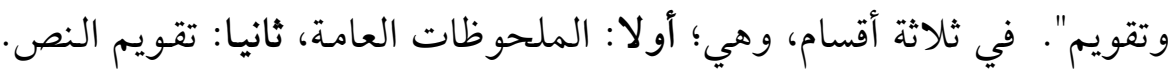
ثالثا: نقد الهو امش والتعليقات.

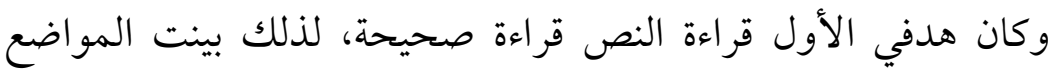

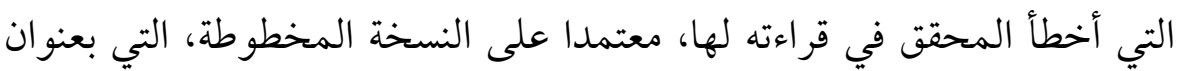

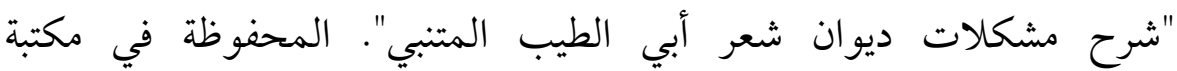

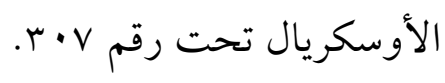

وكذلك اعتمدت على المصادر الأخرى التي نقلت عن ابن فورجة، وخاصة شرح الواحدي، وتفسير أبيات المعاني والنظام.

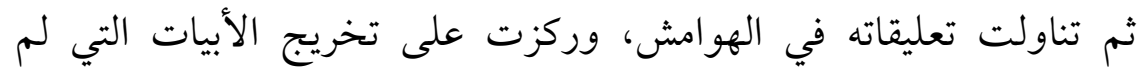
وبعد فلم يكن لي من هدف إلا تقويم نص كتاب نفيس من أنف أنفس الكتب

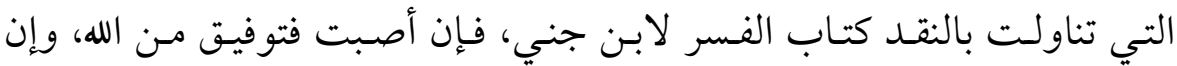

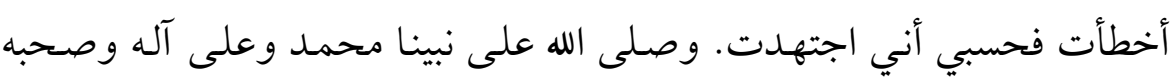

\section{أولا : الملعوظات العامة:}

- لم يطلع على المخطوط الأصلي، فعمله ناقص ابتداء.

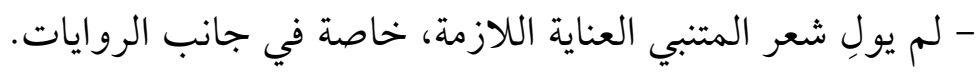

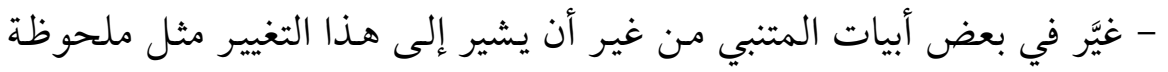

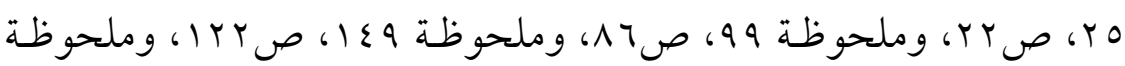

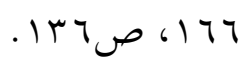

- إقحامه بعض النصوص التي لم تكن في الأصل، معتمدا على المصادر. مثل

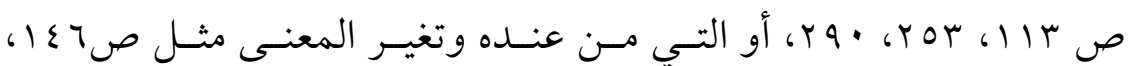




$$
\text { - كثرة يميز النقول عن ابن جني، أو وضعها بين علامتي تنصيص. }
$$

- كثرة السقط مـن الـنص الأصسلي، على الرغم مـن ورودهه بـالطبعتين اللتين

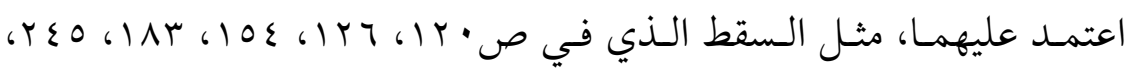

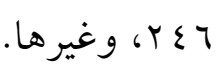

- لم يستفد من المصادر التي نقلت عن المؤلف، حتى يتبين الخلل في النص مئ مأل

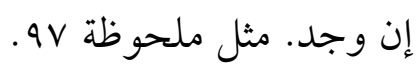

\section{ثانيا : تقويم النص:}

وقع المؤلف في أخطاء كثيـرة جـا في قراءته للنص، والسبب هـو عـدم

اطلاعه على المخطوط الأصلي، واعتماده على طبعتين سقيمتين _كما يقول-

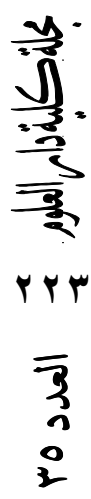

للذلك جـاء النص مشوها بكثرة التصحيف والتحريف و السقط، وقد حاولت

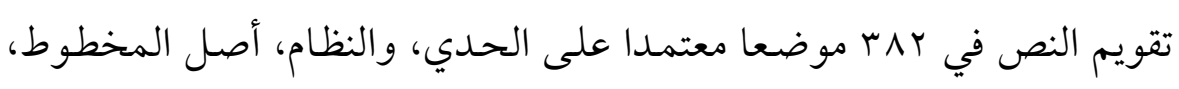
والمصادر التي نقلت عن المؤلف وهب شرح الواحدي، وتفسير أبيات المعاني،

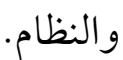

$r r$
$\overline{3}$
3
0 1 - صه "المستجير به عن التنكير" ، خطأ، والصواب: "من التنكير"

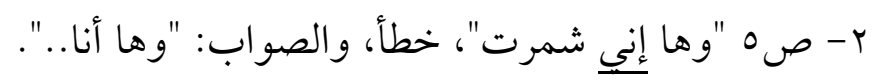

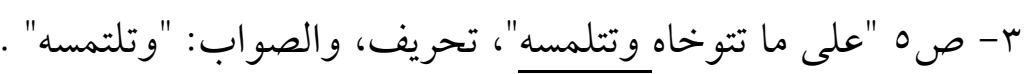

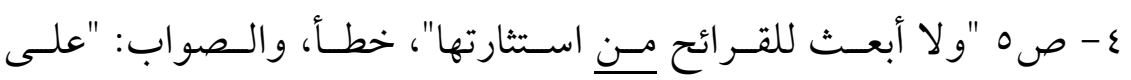

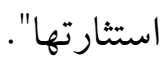

0- صح "ويثير التراب"، هنا سقط، وصحة العبارة: "ويثير بهما التراب".

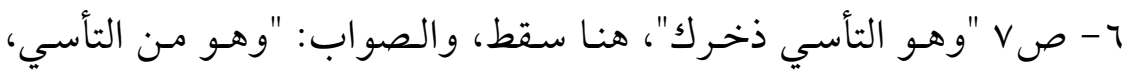

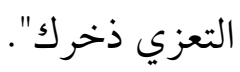

$$
\begin{aligned}
& \text { V- صى " يعني بها ضرب ستة في واحدي"، تحريف، والصواب: "في أحد" } \\
& \text { ^- صـ "ولو قال :عشرة..."، خطأ، والصواب: "ولو قال: عشر". }
\end{aligned}
$$


9- صه "ومـا يجري مجراه في عويص معانيه"، خطأ، والصواب: "مـن عويص معانيه".

• 1- ص • ا "وهو قليل في الشعر"، تحريف، والصواب: "في شعره".

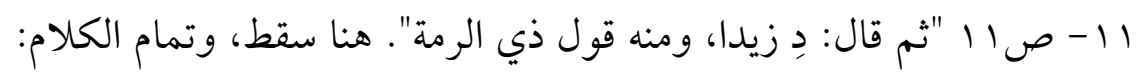

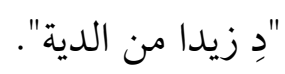

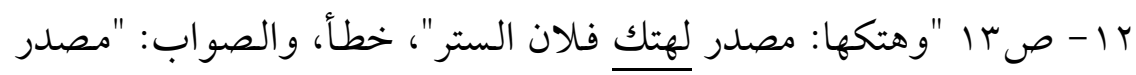
هتك ...

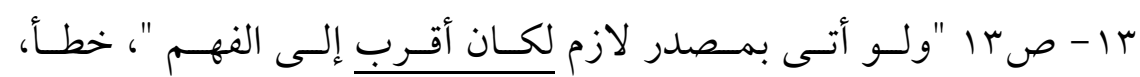

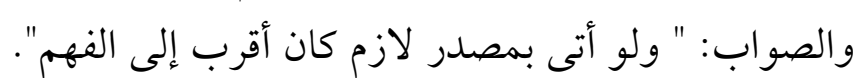

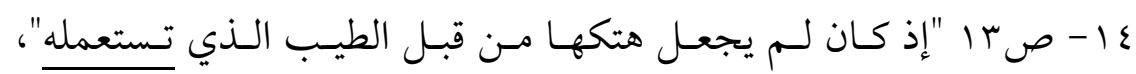
تحريف، والصواب: " إذ كان لم يجعل هتكها من قبل الطيب الذي هن الذي استعملته".

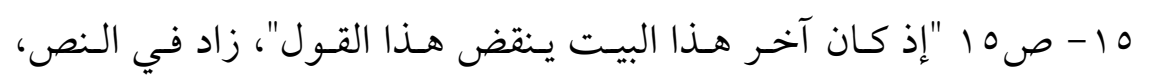

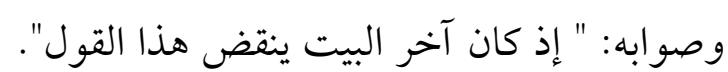

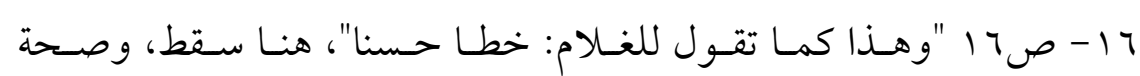
العبارة: "وهذا كما تقول: مثلت للغلام خطا حسنا".

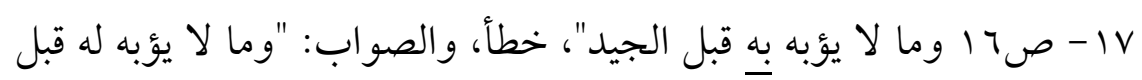

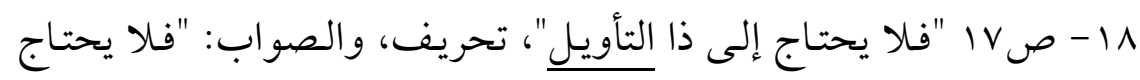
إلى ذا التأول".

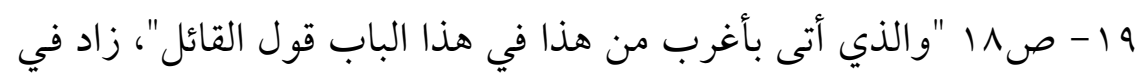
النص، وصو ابه " والذي أتى بأغرب من هذا في هذب هذا هذا الباب القائل".

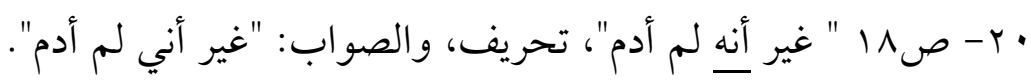

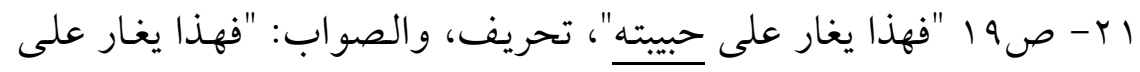


Y Y - ص ا Y "فإنـه يكـون حينئـذ ذمـا وهجــاء"، تحريـف، والـصواب: "ذمــا

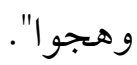

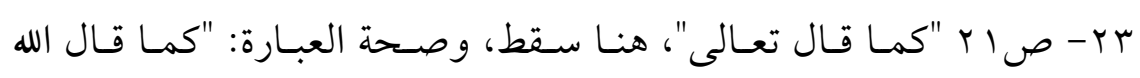
تعالى".

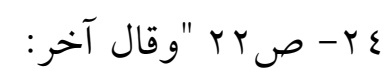

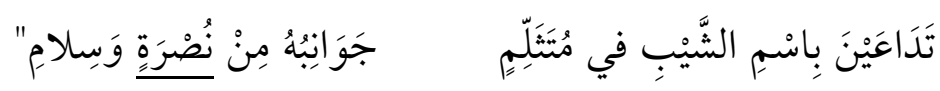

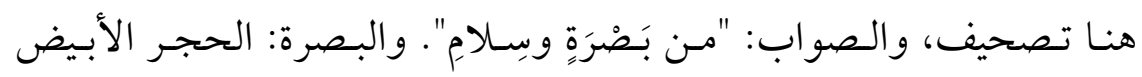

$$
\text { الرخو. }
$$

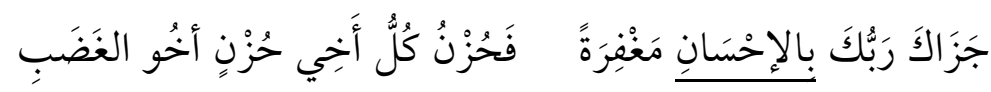

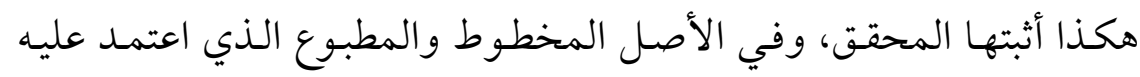

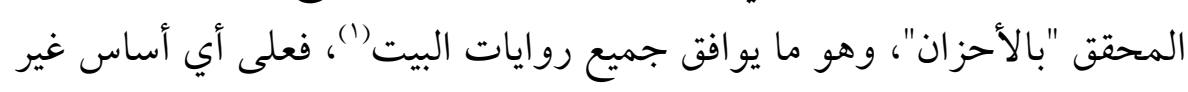

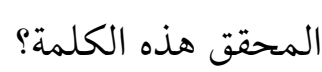

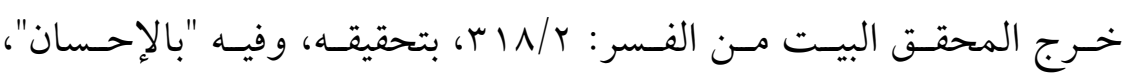

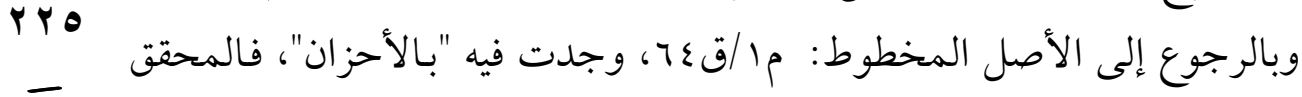
$\overline{3}$
3
1

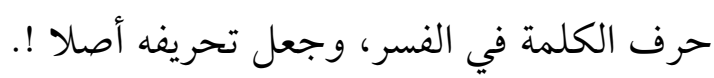

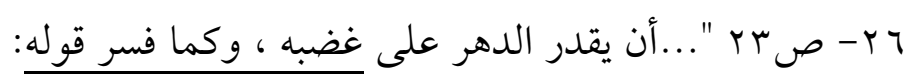

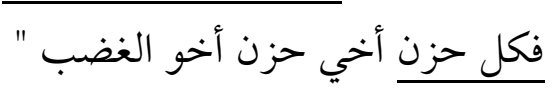

هنا تصحيف، وسقط، وخطأ، والصواب: "أن يقدر الدَّهر على غُّرَّبه، وكما فسر هذين البيتين فقد فسر قوله:

فحزن كل أخي حزن أخو الغضب"

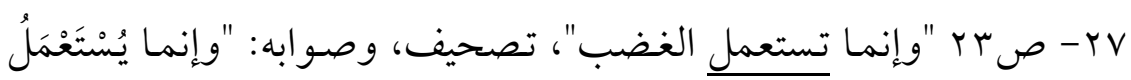
الغضب". ^ץ - ص rr "ولو سرق سارق لغضب عليه". تحريف، وصوابه: "ولو سرقه 


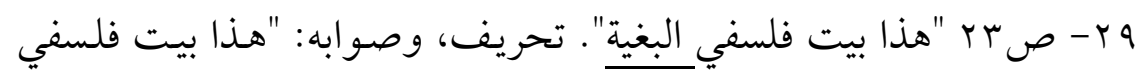

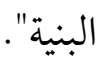

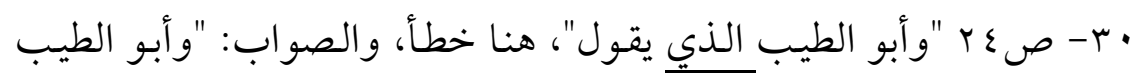
حيث يقول".

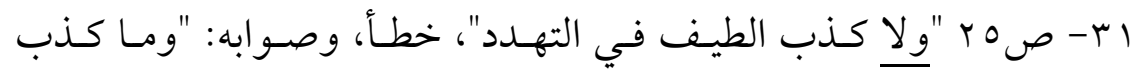
الطيف في التهدد".

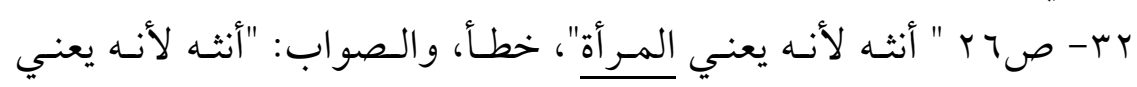

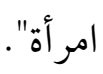

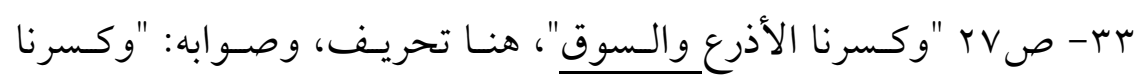

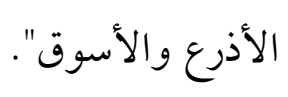

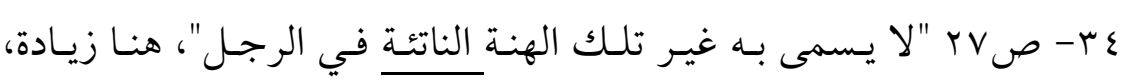

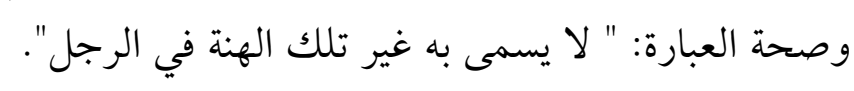

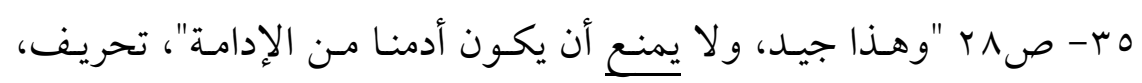

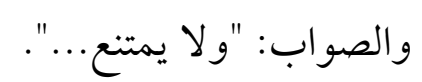

بـ- صرץ "لا أنه يريد المشي فيها". هنا تحريف، والصواب: "لأنه يريد

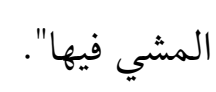

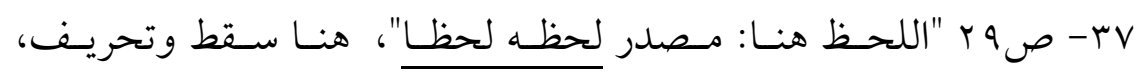

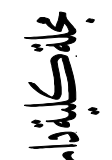

$$
\text { 㿣 }
$$

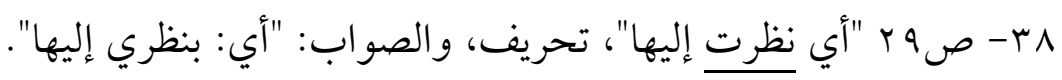

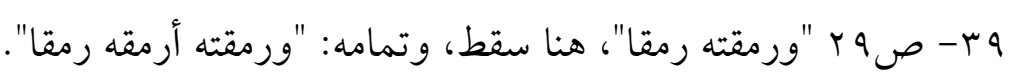

$$
\text { وهو موجود في المطبوع. }
$$

• ع - ص آ "كيف سبق إلى وهمك". هنا تحريف، والصواب: "كيف يسبق

$$
\text { إلى وهمك". }
$$

الع - ص rr "وقال الشيخ أبو الفتح". هنا سقط، وتمانه: "وقد قال الشيخ أبو 


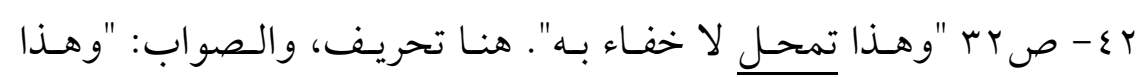
التمحل لا خفاء به".

r r - ص r r "تأثيره في الكواكب: إثـارة الغبـار". هنـا تحريف، و الصواب:

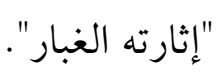

ع - صـ هب "يريد: الأولى أن أعود ". هنا سقط، وتمامه: "يريد: الأولى بي

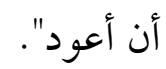

ه ـ - ص حب "و العرب تكتلئ بآذان خيلها و آذان إبلها، قال قائلهم".هنا سقط، وتمامه: "ولهذا قال قائلهم".

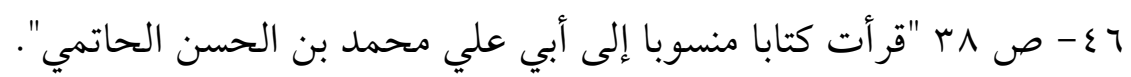
في الأصل المخطوط: "قرأت كتابا منسوبا إلى أبي علي الحسن بن منس محمد

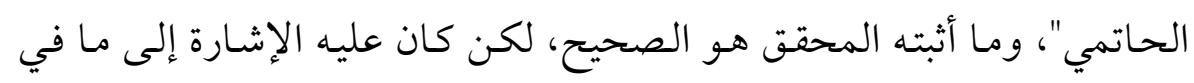

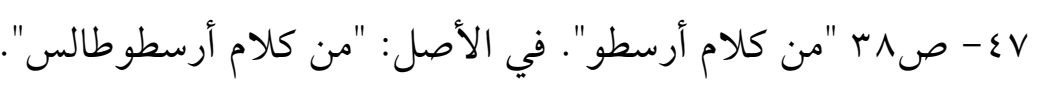

$$
\begin{aligned}
& \text { : }
\end{aligned}
$$

$\overline{3}$
3
2

خلائقه للمكرمات مناسب تناهى إليه كل مجد مؤثل

هنا تحريف، و الصواب: "تناهى إليها كل مجد مؤثل".

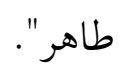

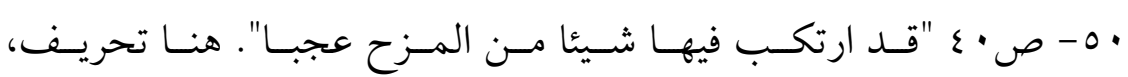

$$
\text { والصواب: "من المزح عجيبا". }
$$

ا 0 - ص اع "كما تقول: لا يمت زيدا". هنا تصحيف، والصواب "لا تمت

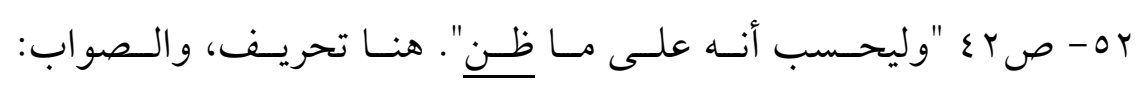
"وليحسب أنه على ما ظنه".

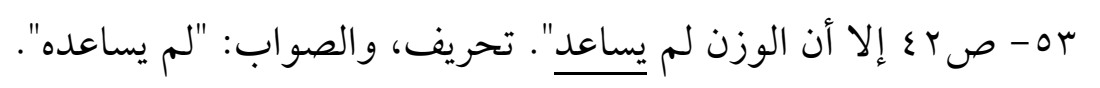




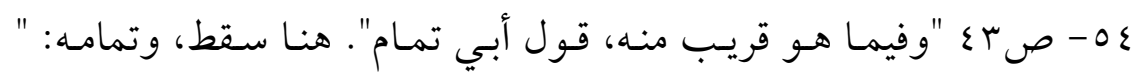

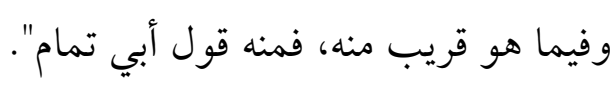

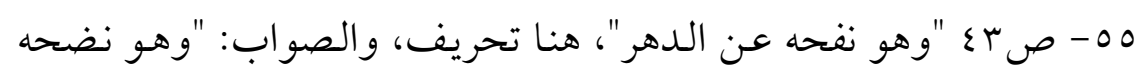

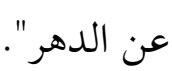

"ه 0 - صن أ "وهر "وإلى هذا أشار بقوله". هنا سقط في موضعين، وصحة العبارة:

$$
\text { "وإلى هذا المعنى أشار أيضا بقوله". }
$$

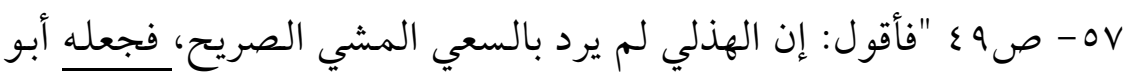

الطيب وثبا", هنا تحريف، والصواب: "فيجعله أبو الطيب وثبا".

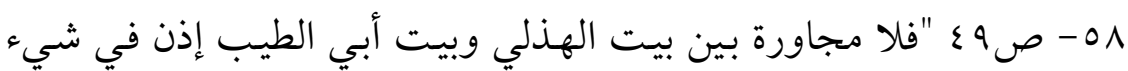

$$
\begin{aligned}
& \text { مما ذكرناه". هنا تحريف، والصواب: "مما ذكره". } \\
& \text { هo- ص اه "كقول عنترة: }
\end{aligned}
$$

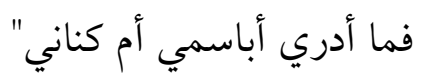

دعوني دعوة والخيل تردي

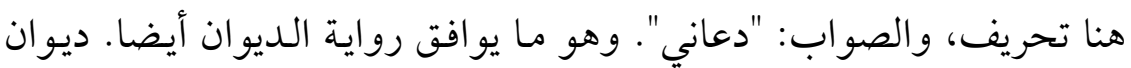

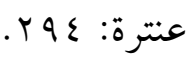

• צ- ص ro "و "وإنما كان يتمناه لوقار الشيب وأبهته". هنا تحريف، والصواب:

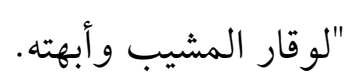

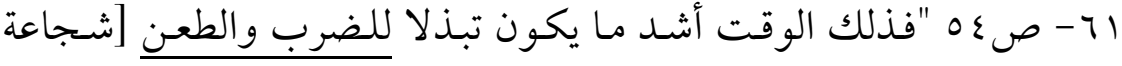

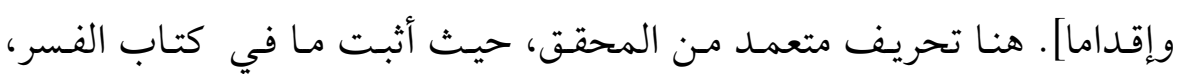

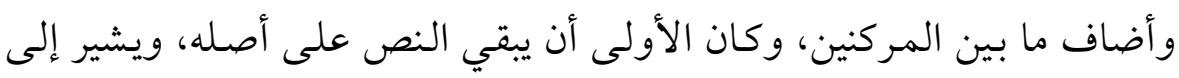

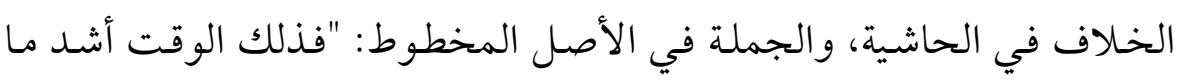
يكون تبذلا للضر اب وللطعان".

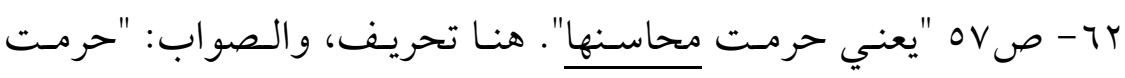

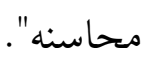
rاT- ص Vه "و كأنه لاحظ قول القائل".هنا سقط، وتمامه: "و كأنه قد لاحظ قول القائل". 
ع - صوه "وهـذا البيـت مـن قصيدة للبحتـري التي أولها". هنـا تحريف،

والصواب: "وهذا البيت في قصيدة البحتري التي أولها".

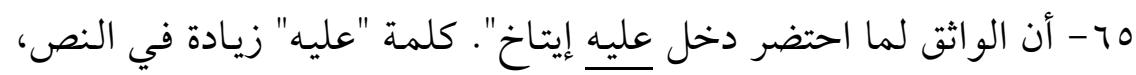

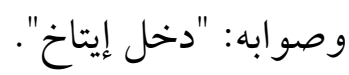

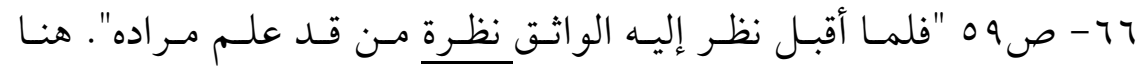

$$
\text { تحريف، والصواب: "نظر من قد علم مراده". }
$$

VIV - ص • T "حتى دخل نصل سيفه بين الحائط وباب البيت". هنا تحريف، والصواب "حتى دخل نعل السيف بين الحائط والباب".

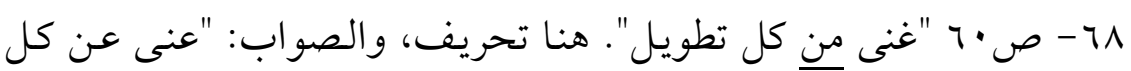
تطويل".

势

9 - ص • r "وسيَّزتها مقبلة لها". هنا تحريف، والصواب: "وسيرتها مستقبلة

•

$$
\text { والصواب: "في كثير من أشعارها". }
$$

rrq

الم- V الج "والشاعر يورد المجاز مورد الحقيقة". هنا تحريف، والصواب:

$\overline{3}$
3
1

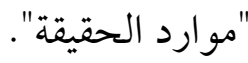

هو ص الج "فشبه غرر الجياد ببياض أيدي هؤ لاء الممدوحين في الناس".

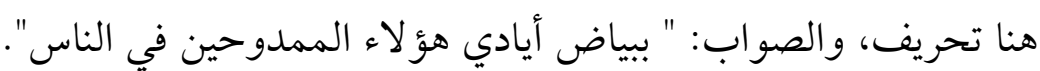

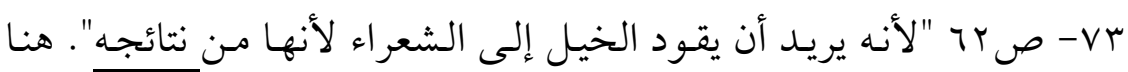

$$
\text { تحريف، والصواب: "لأنها من نتاجه". }
$$

ع V- ص rז "ويوضـح معنى ذلك مـا أنشد الشيخ أبـو العلاء لنفسه". هنـا

تحريف وسقط، وصحته: "ما أنشدنيه الشيخ أبو العلاء أيضا لنفسه".

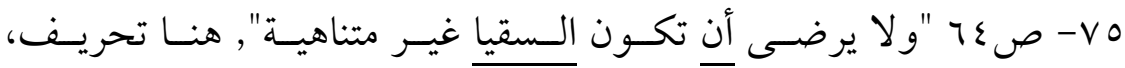

والصواب: "ولا يرضى بأن تكون سُقْيًَا غير متناهية". 
TV - ص ع T "هكـذا رواه الشيخ أبـو الفـتح، وكـذلك رويتـه أيـضا مـن عـدة

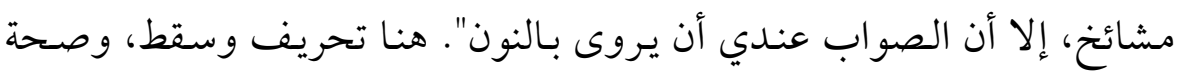
العبارة: " هكذا رواه الشيخ أبو الفتح، وكذا رويته أيضا عن عدة مشائخ، إلا أن إن الصواب عندي أن يروى: سبقنها، بالنون".

- V^ الرجال". هنا تصحيف وتحريف، و الصواب: " والهاء في سبقتها عائدة على الى الرجال، يقول: أنت تشوق الرجال".

ال V9 "بين معنيي المصراعين".

•

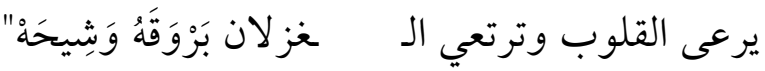

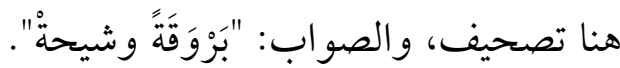

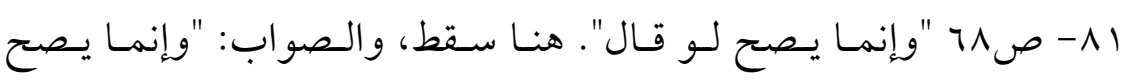

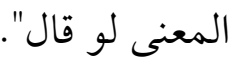

r المرود في هذا البيت المسمار الذي فيه حلقة تدور عليه، لفظة أظنها مولدة. وقد استعملها بعض المحدثين ممن تأخر عن أبي الطيب زمانه، إلا أنه جود ما في

ألمي بعراف النقا وتيممي مهب النعامى واجعلي الليل مرودا". هنا تحريف وسقط، والصواب: " وعنده أن المراود، وهي جمع مرود، ميل الكحل. وعندي أن المـرود في هـذا البيت هـو المسمار الذي فيه حلقـة تـدور

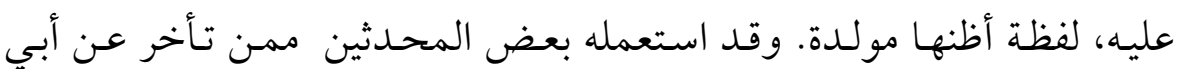
الطيب زمانه، إلا أنه جود ما شاء:

ألمي بعراف النقا وتيمَّني مهب إلهود النعامى واجعلي الليل مرودا". r 1- ص97 "يريد لين أعطافه"، تحريف، والصواب: "يريد لين انعطافه". 
ع ع- ص ا ل "يعلم ما لا يعلمون". خطأ، والصواب: "يعلم ما لا يعلمونه".

1

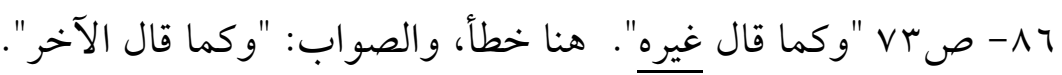

$$
\text { وع }
$$

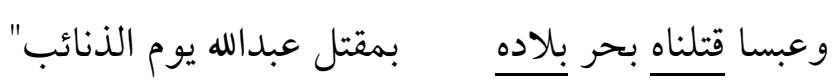

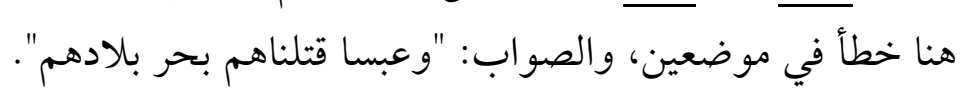

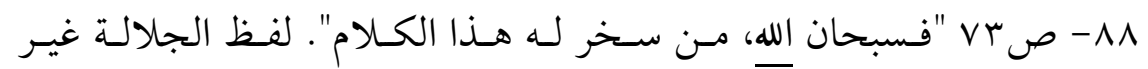

موجود في الأصل، والصواب: "فسبحان من سخر له هذا الكلام".

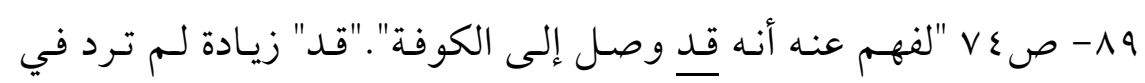

الأصل. - الم.

告

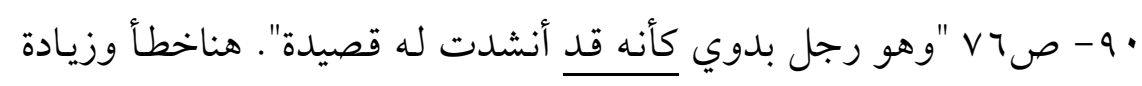

YM

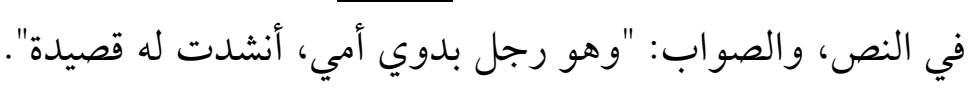

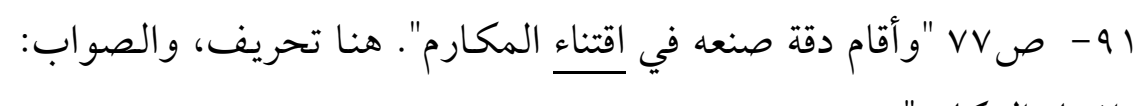

"في إفشاء المكارم".

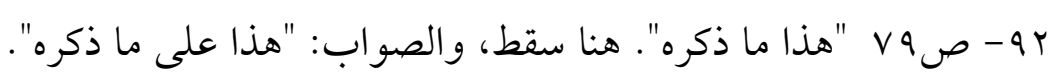

$\overline{3}$
3
0
1

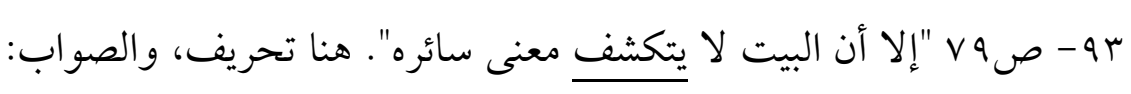

"لا يكشف معنى سائره".

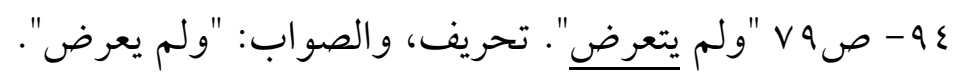

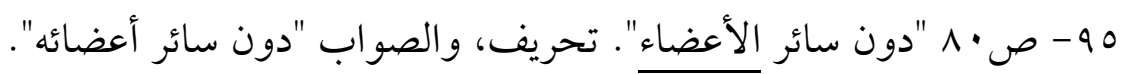

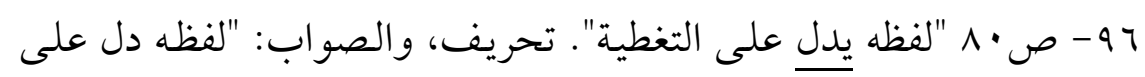

التغطية".

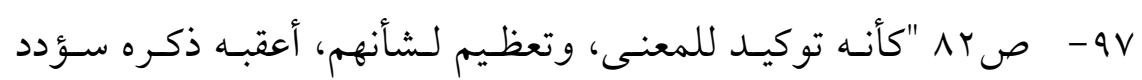

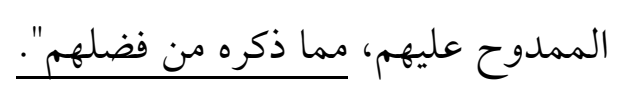

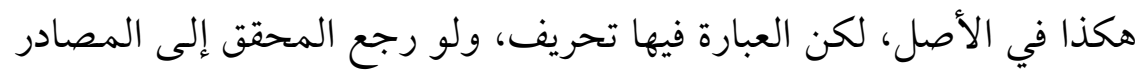

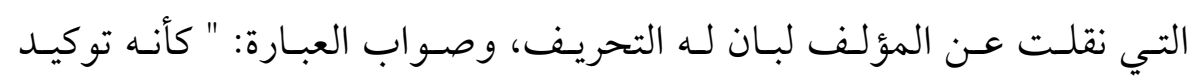


للمعنى، وتعظيم لشأنهم، أعقبه ذكره سؤدد الممدوح عليهم، مع ما ذكر من

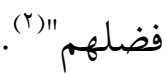

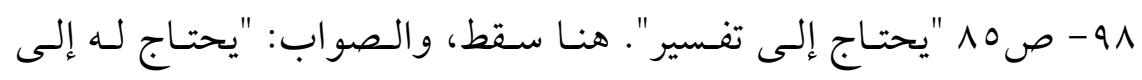

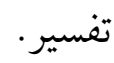

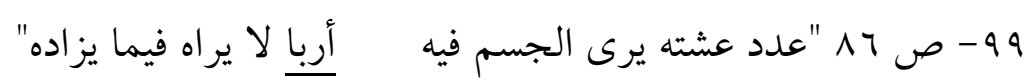

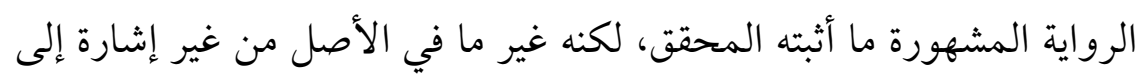
ذلك، حيث الرواية في الأصل: "زائدا لا يراه".

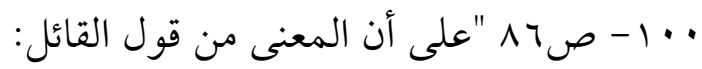

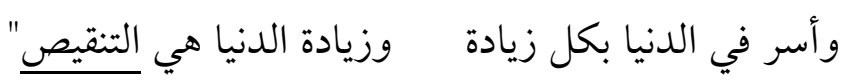
هنا تحريف، والصواب: "هي النقص".

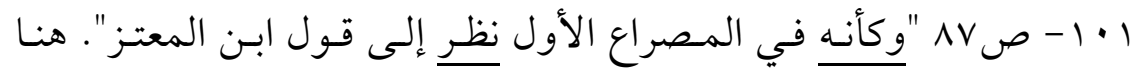

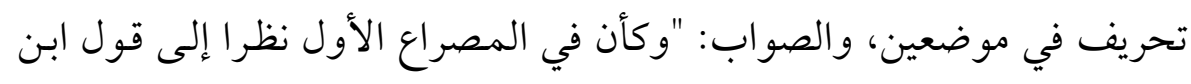

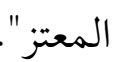

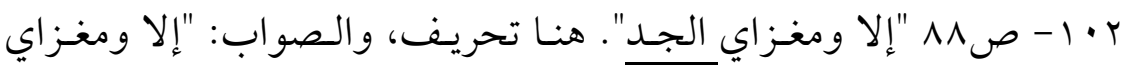

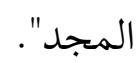

r • ا - "وأخذي مجد، وعطائي مجدي". زاد كلمة "مجد" الثانية، وليست في

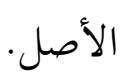
ع • - صـه "فما أكثر ما جاء نظير هذا في شعره وشعر غيره وأجوده". هنا سقط، وتمام العبارة: "وأجوده قول القائل".

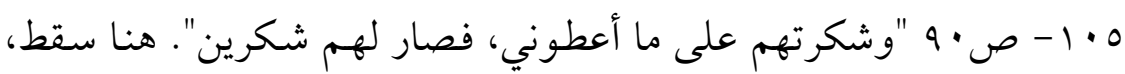
وتمامه: "فصار شكري لهم شكرين".

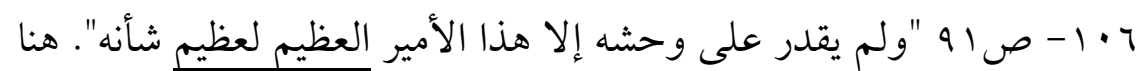

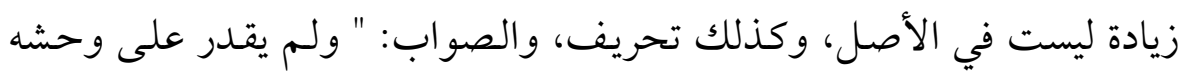
إلا هذا الأمير لعظم شأنه".

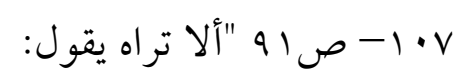




$$
\text { فرد كيافوخ البعير الأصيد يسار في مضيقه والجلمد" }
$$

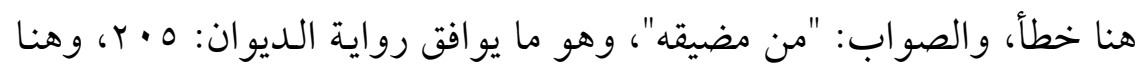

$$
\text { يثبت المحقق عدم اهتمامه بشعر المتنبي. }
$$

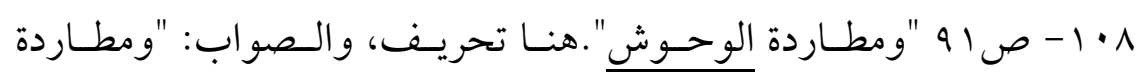

$$
\text { الوحش". }
$$

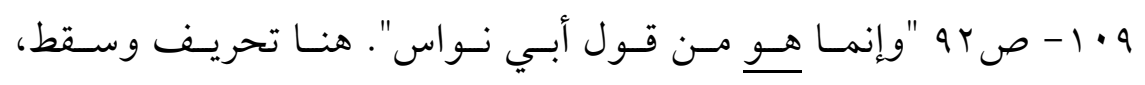

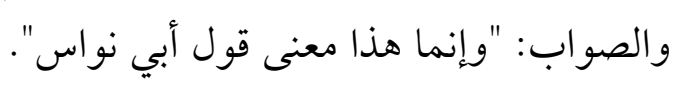

• 11 - ص ب ه "ومثله". هنا سقط، وتمام العبارة: "ومثله له".

111

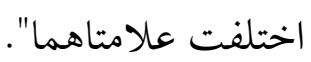

喜

rrT

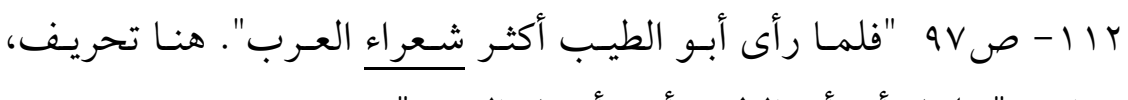

$$
\begin{aligned}
& \text { والصواب: " فلما رأى أبو الطيب أكثر أشعار العرب". }
\end{aligned}
$$

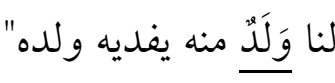

$$
\begin{aligned}
& \text { " } 999 \text { - }
\end{aligned}
$$

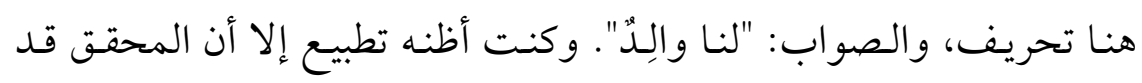

ضبط الكلمة بالشكل التام، مع أنه أثثتها صحيحة في الصفحة 90.

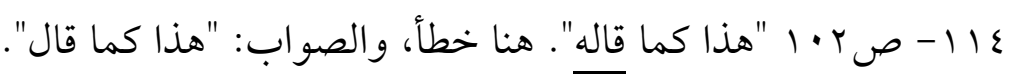

10 - 110

"فعن 11 - ص ع • 1 "ليس بذي رائحة فيغني عن الشم". هنا خطأ، والصواب:

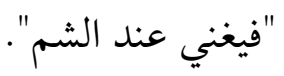

IV V - ص ه • 1 "وقد قيل: الكرينة: المغنية، وأنشد بيت الطرماح". هنا سقط وتحريف، والصواب: " وقد قيل: إن الكرينةً: المغنية، وأنشدوا بيت الطرماح".

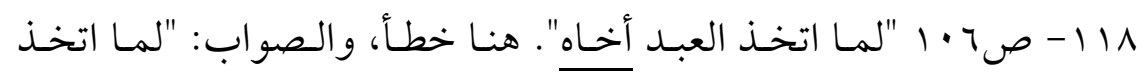
العبد أخا".

$$
\begin{aligned}
& 119 \text { - ص V • 1 "أو ما أشبه ذلك". هنا خطأ، و الصواب: "أو ما أشبهه". } \\
& \text { • r ا - صـ • ا "كقول القائل: }
\end{aligned}
$$




$$
\begin{aligned}
& \text { فإنها خطرات من وساوسه يعطي ويمنع لا بخلا ولا كرما" } \\
& \text { هنا تحريف، والصواب: "كأنها خطرات" بعطي وتئ }
\end{aligned}
$$

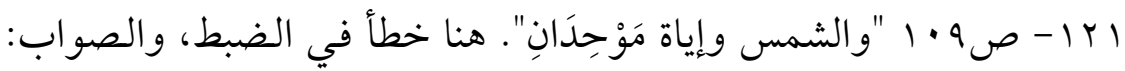

$$
\text { "و الشمس وإياة مُوَحَدَانِ". }
$$

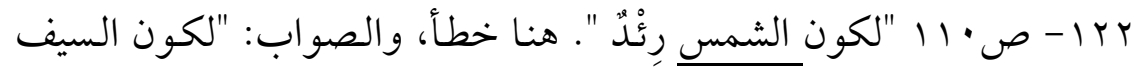

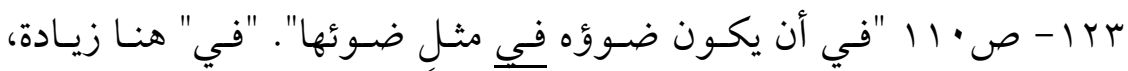

$$
\begin{aligned}
& \text { والصواب: " في أن يكون ضوؤه مثلَ ضوئها". }
\end{aligned}
$$

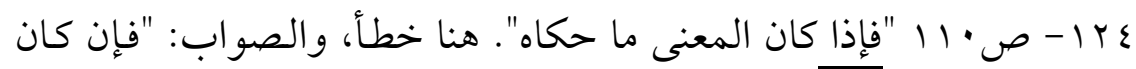

$$
\text { المعنى ما حكاه". }
$$

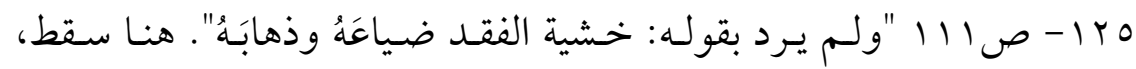

$$
\text { وصو ابه: "ولم يرد بقوله: خشية الفقد خشية ضياعِهِ وَذَهَابهِهِ }
$$

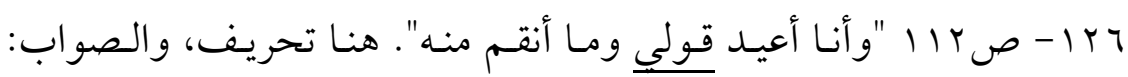

$$
\text { "و أنا أعيد قوله وما أنقم منه". }
$$

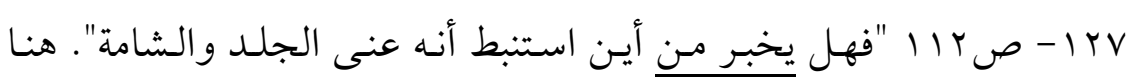

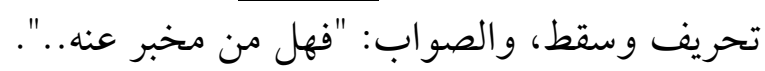

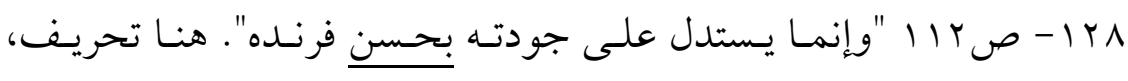

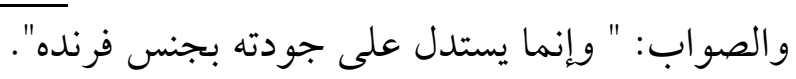

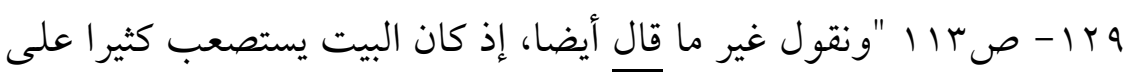

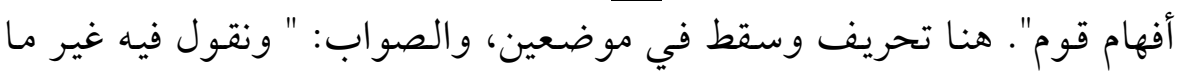

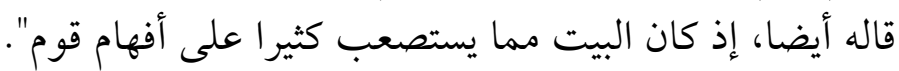

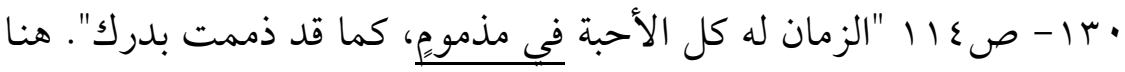

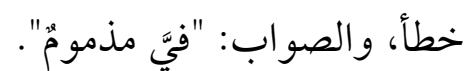

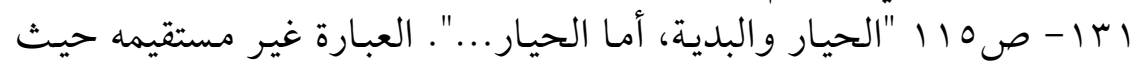

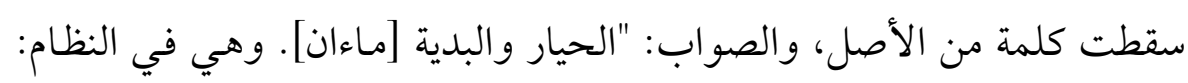


ץ با - ص 10 | "وبينهما مسيرة ليلة". هنا تحريف، والصواب: "مسير ليلة". بrا - ص إ 1 "فقال في بعض فصوله". هنا تصحيف، والصواب: "فقال في بعض فضوله".

ع ז1 - ص7 $1 \mid$ |"إذ كانت شفرته في العمارة مـن الحيار". هنا سقط بمقدار سطر، وتمامه: "إذ كانت شفرته في العمارة، ولا يجوز أن تكون شفرته بالبدية والقائم أدنى إلى العمارة من الحيار". وهذا السقط موجود في الطبعتين اللتين اعتمد عليهما.

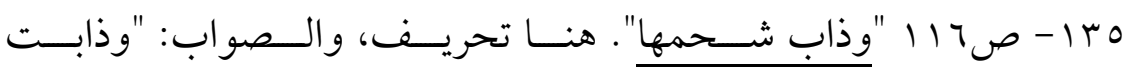
شحومهما".

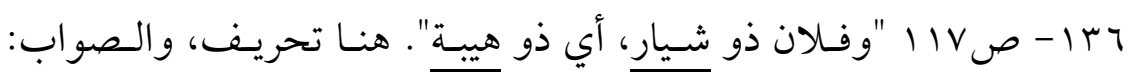

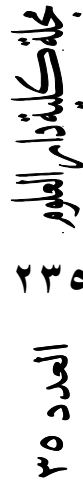

$$
\begin{aligned}
& \text { "وفلان ذو شارة؛ أي: ذو هيئة". }
\end{aligned}
$$

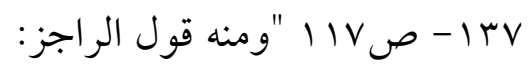

$$
\begin{aligned}
& \text { كأنها من بدن وشارةٌ والحلي حلي التبن والحجارة". } \\
& \text { هنا تحريف، والصواب: " والحلي حلي التِبّر والحجارة". }
\end{aligned}
$$

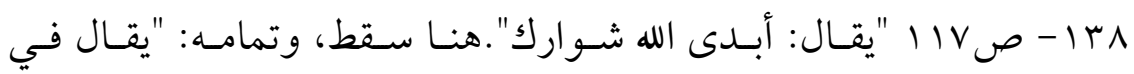

• ع ا - ص1111 "يقول: الخمـر قد خالطهيا المسكك". هنا خطأ، والصواب:

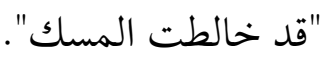

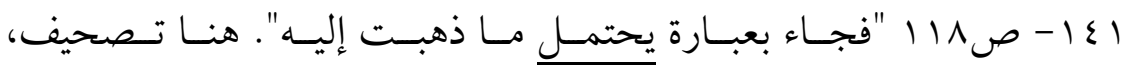
و الصواب: "تحتمل ما ذهبت إليه.

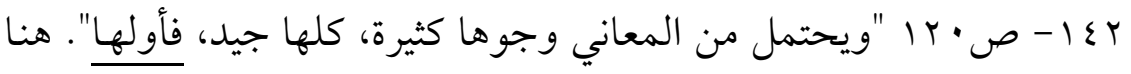

$$
\text { خطأ، والصواب: "فأحدها". }
$$

rع ا - ص · r ا "وهو أنه لا قوة له". خطأ، والصواب: "وأنه لا قوة له". 


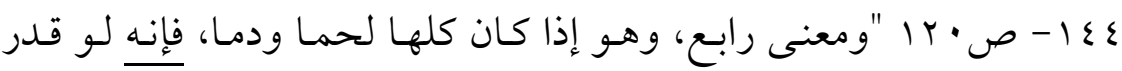

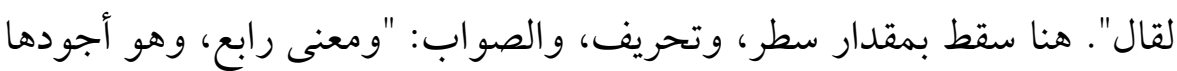
كلها، وهو أن يعني أنها كأنها شعر قد تجسم ناقة فكلها شعر إذ كان كلها لحما ودما، وكأنه لو قدر لقال".

وما أسقطه المحقق موجود في المطبوع الذي اعتمد عليه.

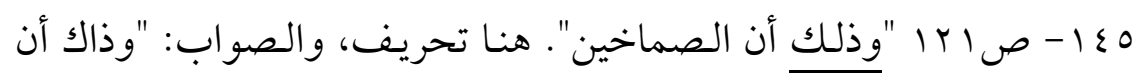

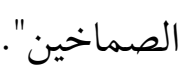

צ أ - ص ا Y I "وقد تكلمت الأطباء في ذلك وفي ماهيته". هنا تحريف،

$$
\text { والصواب: "وفي مآتيه". }
$$

V \ ا - ص ا Y | "وقد روي عن عائشة أنها قالت". هنا سقط، وتمام الكلام:

$$
\text { "وقد روي عن عائشة، رضي الله عنها، أنها قالت". }
$$

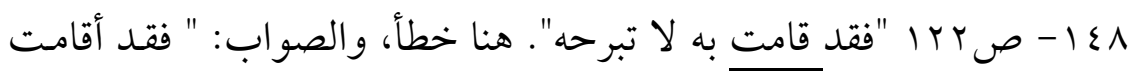

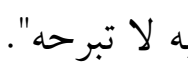

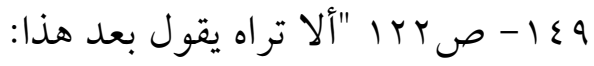

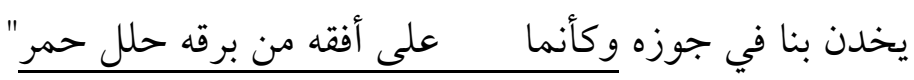

$$
\begin{aligned}
& \text { هنا خطأ في رواية البيت، والصواب: }
\end{aligned}
$$

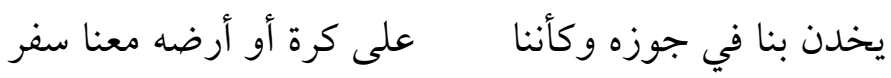

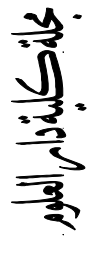

דיד

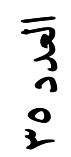
وهو ما يوافق رواية الديوان: IV7، الع والعجيب أن المحقق أحال في تخريج البيت إلى الفسر: ب/ به 1، ولم يتنبه إلى الخطأ، حيث إن رواية الفسر مثل رواية المؤلف.

• 10

$$
\text { زيادة ليست في الأصل. }
$$

101 - " صع r ا "ثم قال: وباقيه أكثر مما مضى؛ أي: باقي الليل". قوله: "أكثر مما مضى" زيادة ليست في الأصل. ror - ص ع r ا "لم يفهمه من بدء". هنا تحريف، والصواب: "من رده". 
ro 10 ص ع با "والعرب تذكر مع الطعن النحرِ". هنا تحريف، و الصواب: " والعرب تذكر مع الطعن النحور".

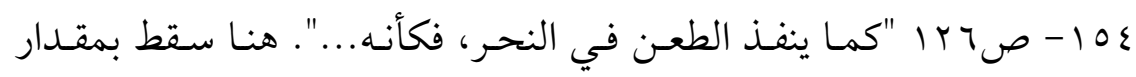

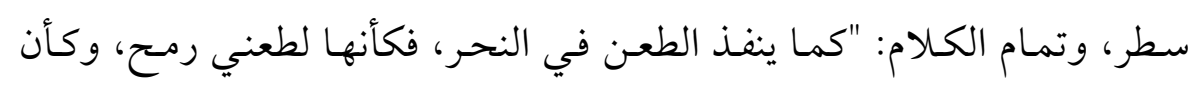
الصفصف ومداه نحر يقصد بالطعن، فكأنه لو تمكن لقال:...".

$$
100
$$

يتقيلون ظلال كل مطهم أجل الظليم وربقة السرحان" هنا تحريف، وصواب إنشاد البيت: "يتفيئون ظلال".

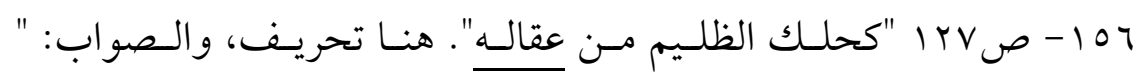
كحلك الظليم من عقالٍ".

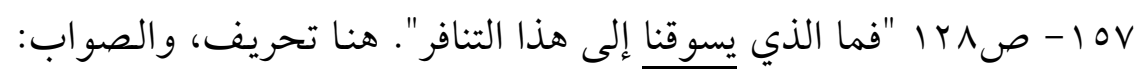
" فما الذي يسومنا إلى هذا التنافر".

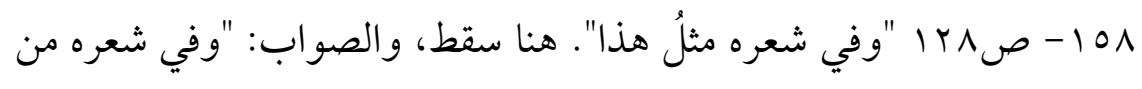
مثلِ هذا".

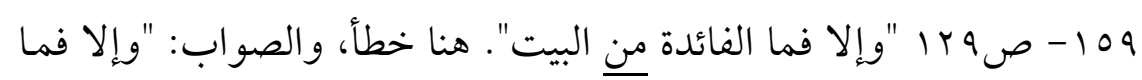

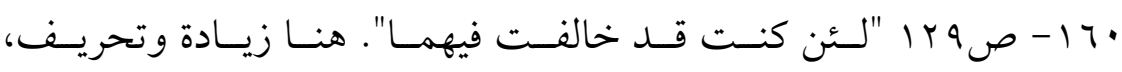

$$
\text { والصواب: "لئن كنت خالفت بينهما". }
$$

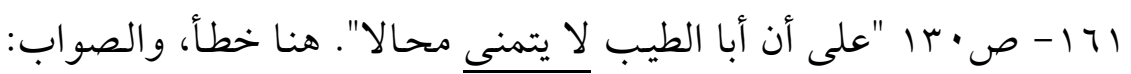

$$
\text { "على أن أبا الطيب لم يتمنَّ محالا". }
$$

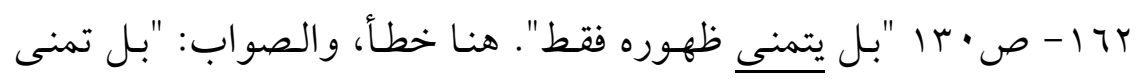
ظهوره فقط".

"r 1 - ص صr I ا "فجاء بأذني عناق". هنا خطأ، ولا معنى للجملة، و الصواب:

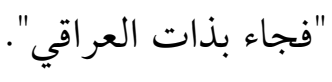




$$
\text { بلغت أبا جاد". } 17 \text { - ص عَب "فتقول: تليـت أبـا جاد". هنا تحريف، والصواب: "فتقول: }
$$

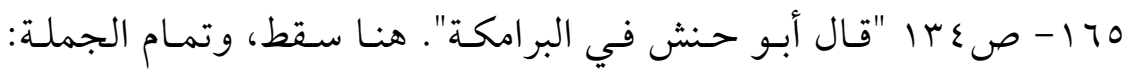

$$
\begin{aligned}
& \text { "و كما قال أبو حنث". } \\
& \text { } 77 \text { - ص }
\end{aligned}
$$

هذي برزت لنا فهجت نسيسا مث انثيت وما شفيت نسيسا"

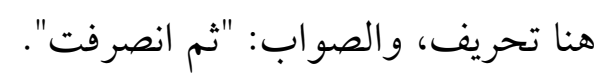

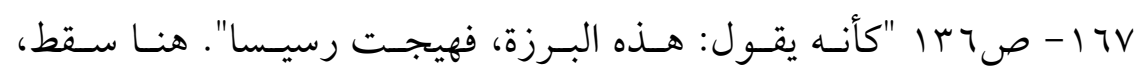

$$
\text { والصواب: "هذه البرزة برزت فهيجت نسيسا". }
$$

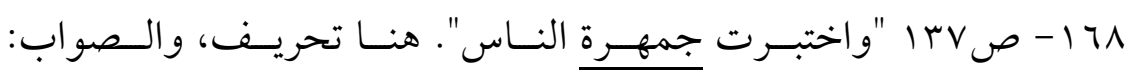

$$
\text { "واختبرت جمهور الناس". }
$$

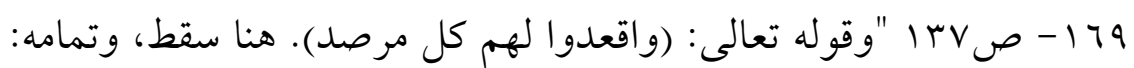

$$
\text { "وقوله تعالى: (واقعدوا لهم كل مرصد)؛ أي: على كل مرصد. }
$$

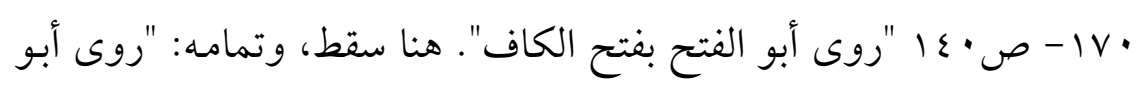

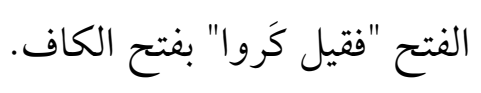

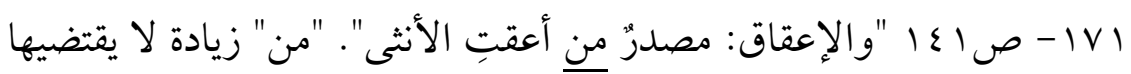

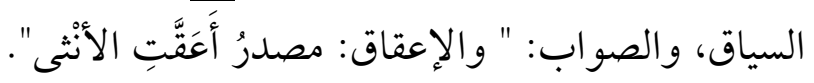

الجد - IVr

$$
\text { بجيد". }
$$

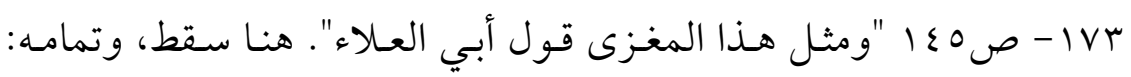

$$
\text { "قول الشيخ أبي العلاء". }
$$

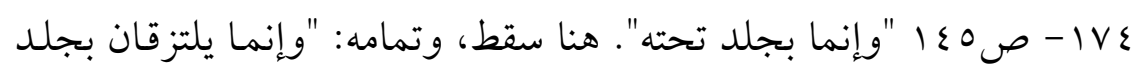

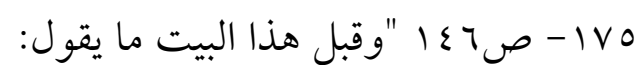

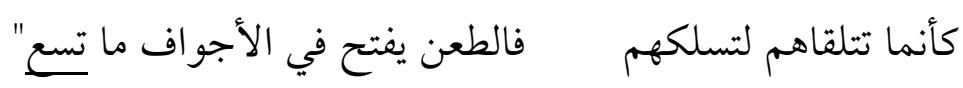




$$
\begin{aligned}
& \text { هنا تصحيف، و الصواب: "في الأجواف ما يسع". }
\end{aligned}
$$

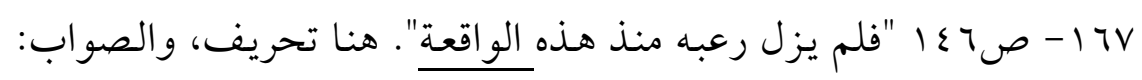

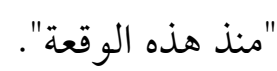

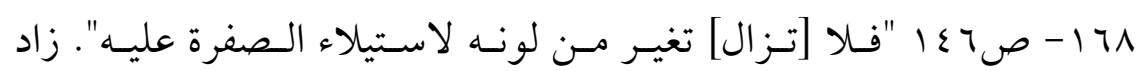

$$
\begin{aligned}
& \text { المحقق كلمة "تزال"، والسياق لا يقتضيها، بل غيرت المعنى . }
\end{aligned}
$$

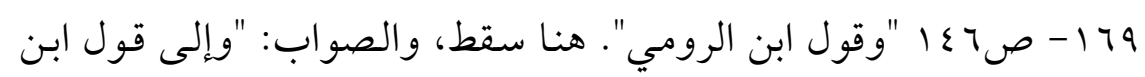

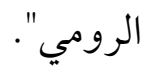

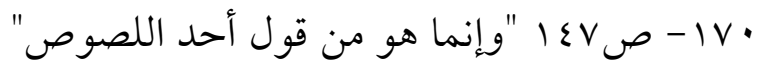

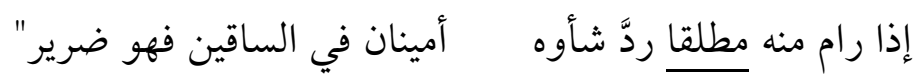

$$
\begin{aligned}
& \text { هنا تحريف، و الصواب: "رام منه مطلعا". }
\end{aligned}
$$

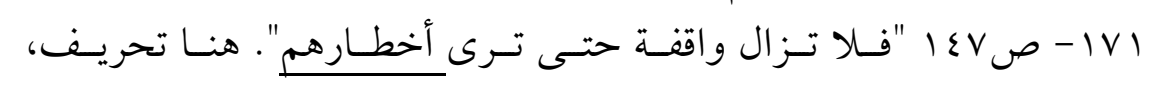

IVr

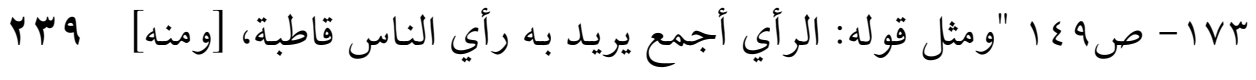

3
3
1

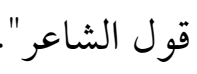

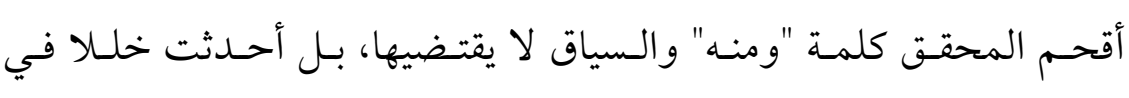

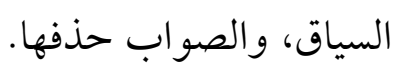

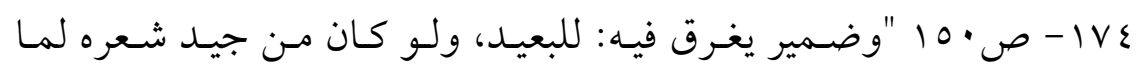

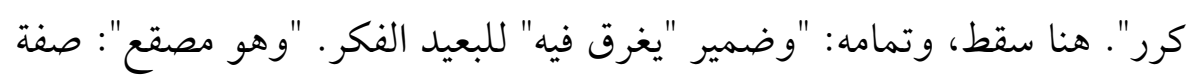

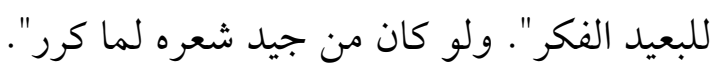

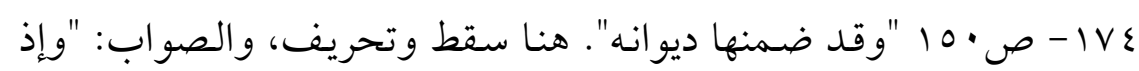

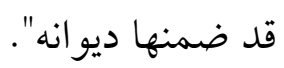

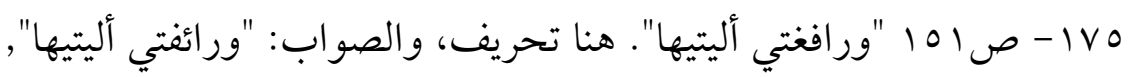

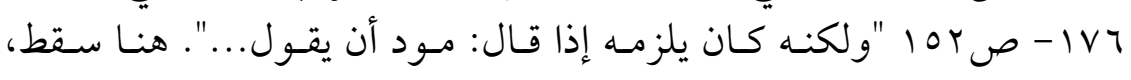
وتمام الكلام: " ولكنه كان يلزمه إذا قال: ومغنى العلى مود أن يقول...". 
IVV

$$
\text { و الصواب: "بالمغنى". }
$$

IVA - ص ع ا "ويقـال: أفاقـت الناقـة: إذا اجتمعست الفيقـة في ضـرعها،

وفاقت الناقة بدرتها: إذا أرسلتها على ذلك، وهي الفيقة".

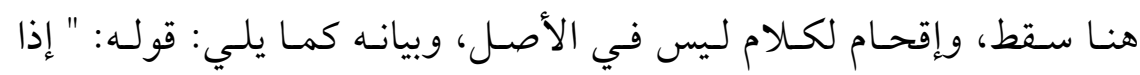

اجتمعت الفيقة في ضرعها، وفاقت الناقة بدرتها: إذا أرسلتها على ذلك". كلام

$$
\text { مقحم ليس في الأصل، وأقحمه المحقق من لسان العرب "فوق". }
$$

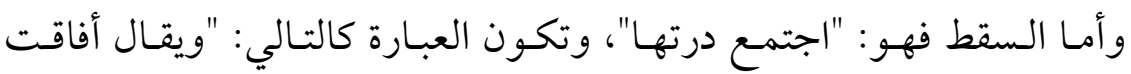

$$
\text { الناقة: اجتمع درتها، وهي الفيقة". }
$$

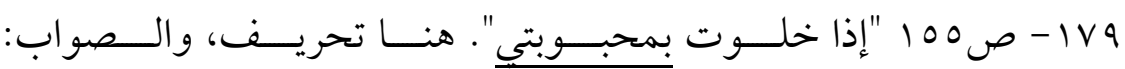

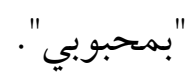

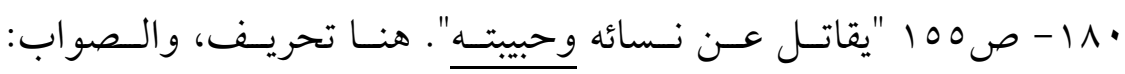

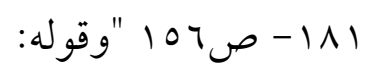

ولم أر كالألحاظ يوم رحيلهم بعثن بكل القتل في كل مشفق"

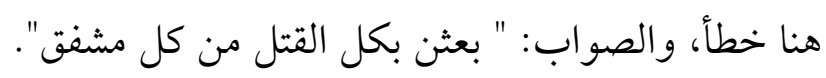

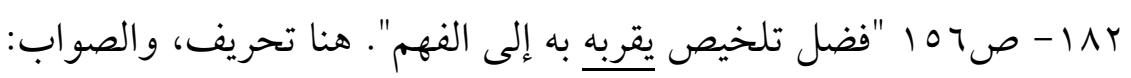

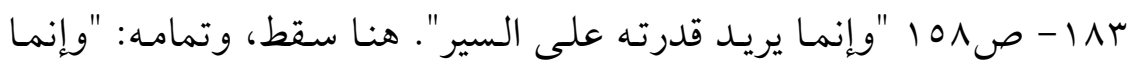

$$
\text { يريد بذلك قدرته على السير". }
$$

ع11 - صـ101 ا "ويجوز أن يعني ما ارفض عن حافتي مضرب الصاقور".هنا

زيادة كلمة وتحريف أخرى، والصواب: " ويجوز أن يعني ما عن جانبي مضرب

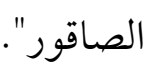

111 - ص • 1 ا "أي: من حيث يوضع عليه الرحل". هنا سقط، وتمامه: "من

$$
\text { حيث يوضع عليه الرحل من ظهره، يريد طول عنقه". }
$$


711 - ص • 1 ا "وفي الشعر القديم يصف جملا". هنا سقط، وتمامه: " وفي

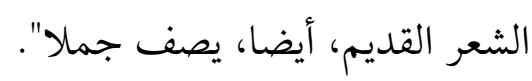

INV

$$
\text { والصواب: "الضَّيْمران". }
$$

1111 - ص آ| "وتجد في كتب الطب: بزر الريحان، يعنون: الشاهسفرم.

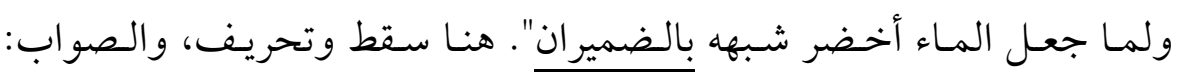
"وتجد في كتب الطب: بزر الريحان، يعنون: بزر الشاهسفرم. ولما جعل الماء أخضر شبهه بالضيمران".

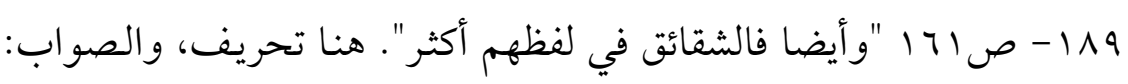
" وأيضا فالشقائق أكثر في لفظهم".

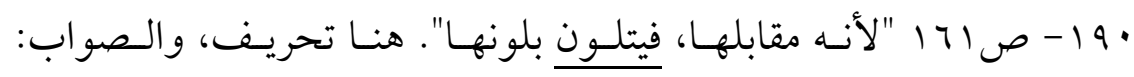

191 - ص سج | "لكنك لم تبتلي". هنا تحريف، والصواب: "لم تبلي".

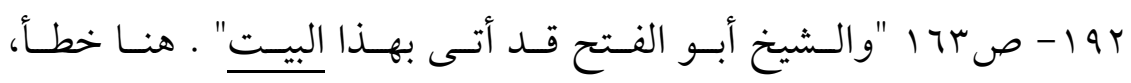

$r \leq 1$ والصواب: " والشيخ أبو الفتح قد أتى بهذا المعنى". $\overline{3}$
3
1

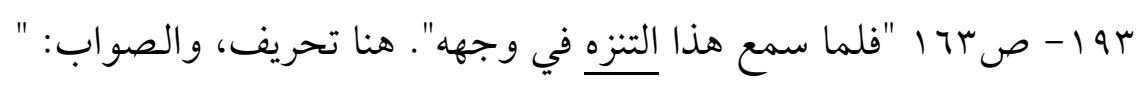
فلما سمع هذا يتنزه في وجهه".

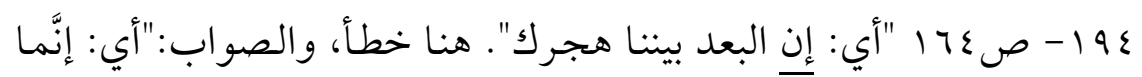

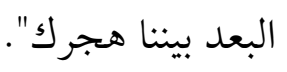

أنفاسنا عل 190

$$
\text { أنفاسنا على الأرماق". }
$$

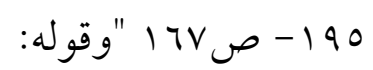

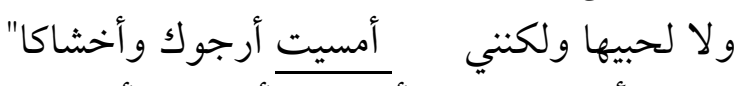

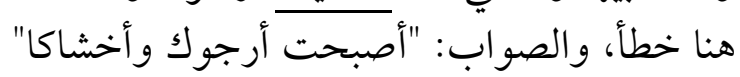

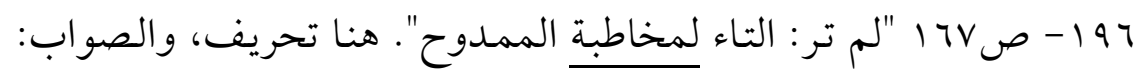
"التاء للمخاطب الممدوح". 


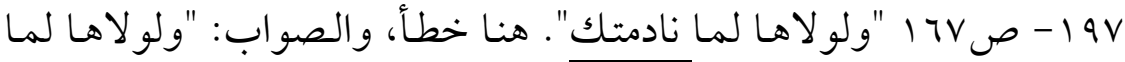

191 - صـ1 ا "فتأمله يتضح لك". هنا تحريف، والصواب: "يضح لك".

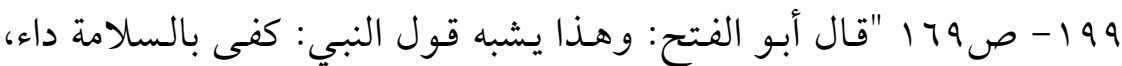

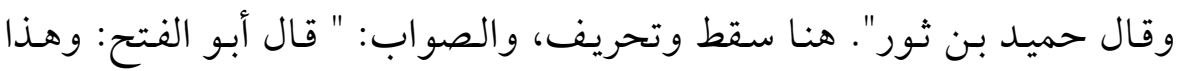
يشبه قول النبي صلى الله عليه: كفى بالسلامة داء، وقول حول حميد".

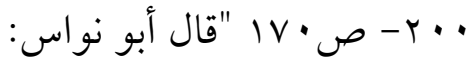
وإن جرت الألفاظ منا بمدحة لغيرك إنسانا فأنت الذي نعني" هنا تحريف، والصواب: "جرت الألفاظ يوما".

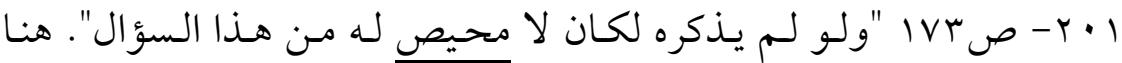
تحريف، والصواب: "لكان لا مخلص له ".

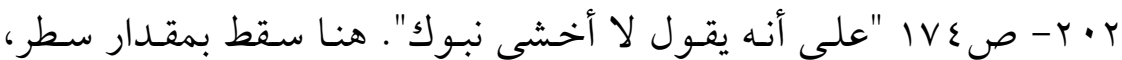

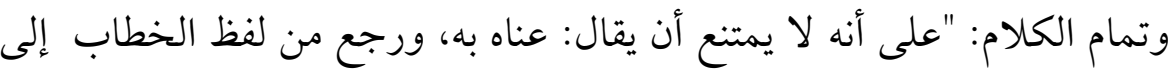

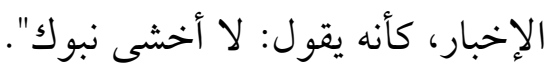

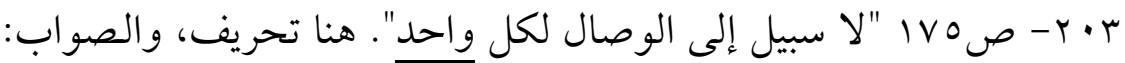

أهل اللغة، من السبط والبطر". هنا تحريف، والصواب: "من السبط والطر".

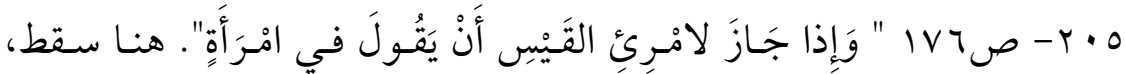
وتمامه: "في صفة امرأة".

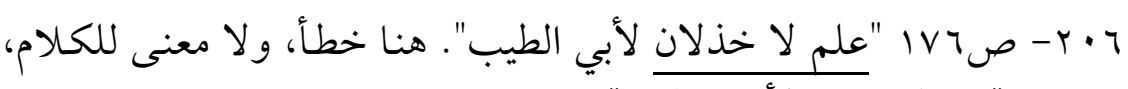

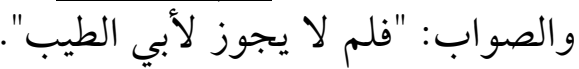

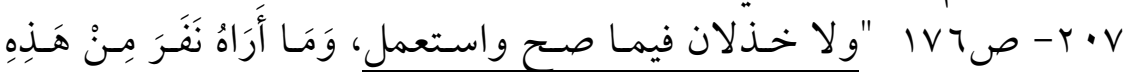

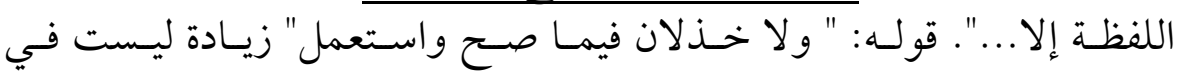

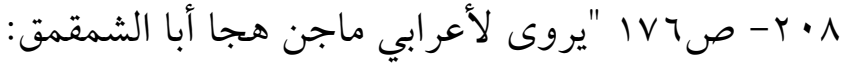




$$
\text { هنا تحريف، بأير بغل مسبطر فويق القاع كالوتر المطوق" }
$$

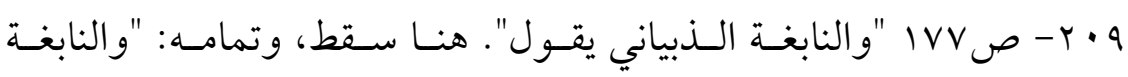

$$
\text { الذبياني حيث يقول". }
$$

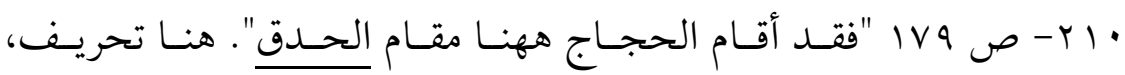

$$
\text { و الصواب: "مقام الحدقة". }
$$

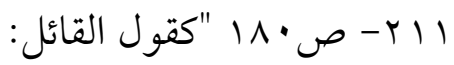

أليس يضر العين أن تكثر البكا ويمنع منها نومها وسرورها"

$$
\text { هنا تحريف، و الصواب: "أليس يضير...". }
$$

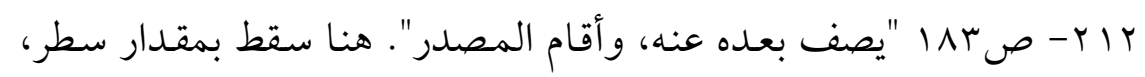

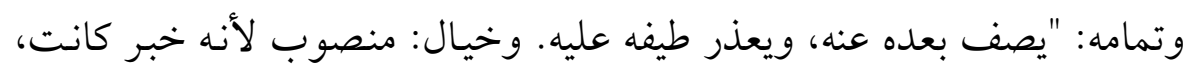
وليس مفعول إعادته، و أقام المصدر".

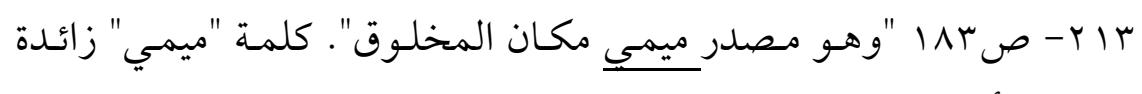

$$
\text { ليست في الأصل. }
$$

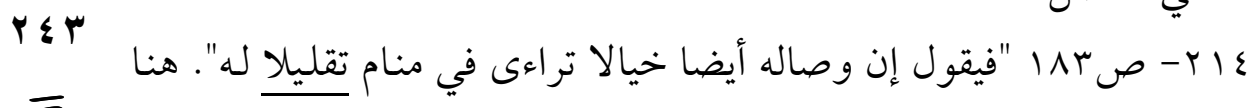

تعليلا له".

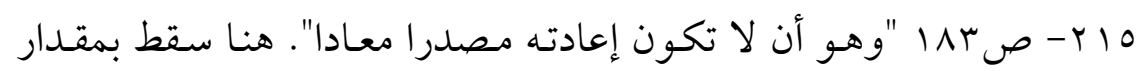

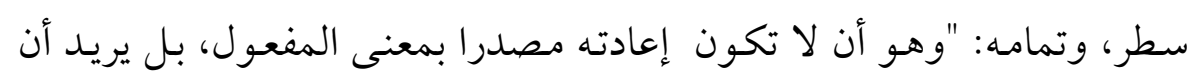
الإعادة نفسها كانت خيالا لخياله، وكان أيضا معادا".

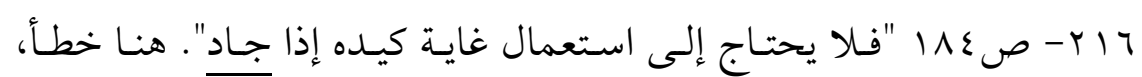

$$
\text { و الصواب: "إذا حارب". }
$$

"بني كما كانت أوائلنا تبني ونفعل مثلما فعلوا"

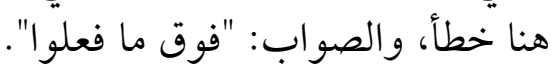


:1100-r|1

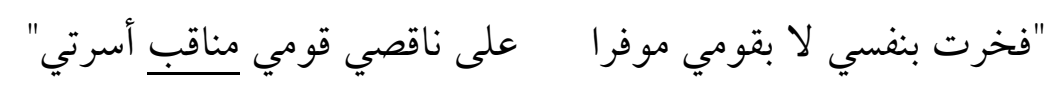
هنا خطأ، والصواب: "مآثر أسرتي".

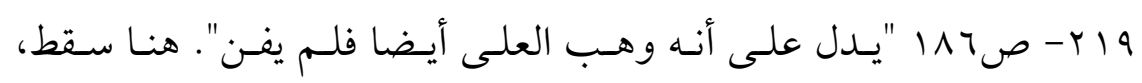

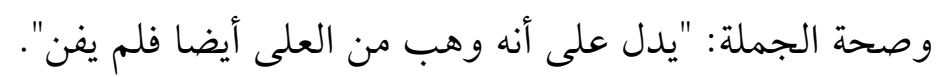

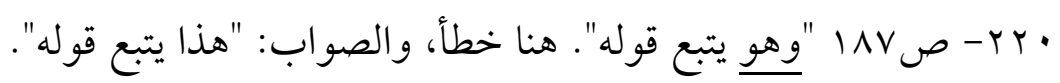

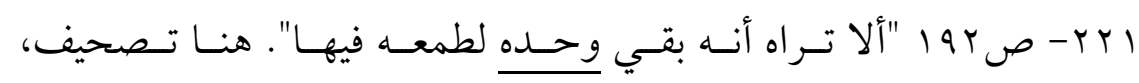

$$
\text { و والصواب: "بقي وجده". }
$$

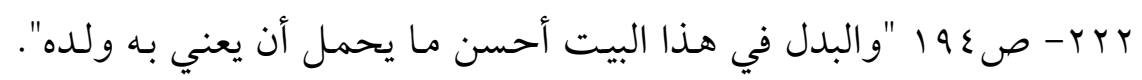

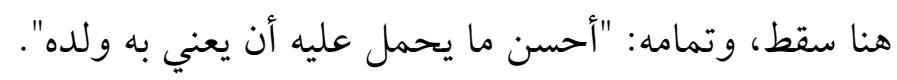

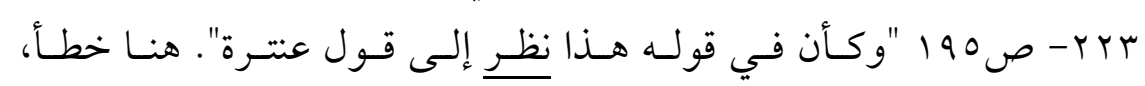
والصواب: "و كأن في قوله هذا نظرا".

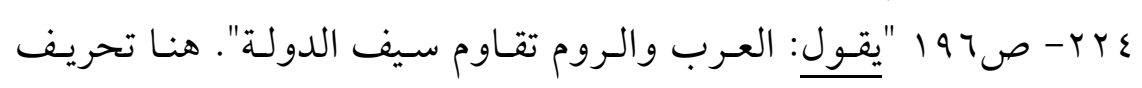

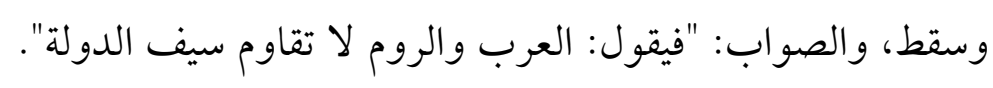

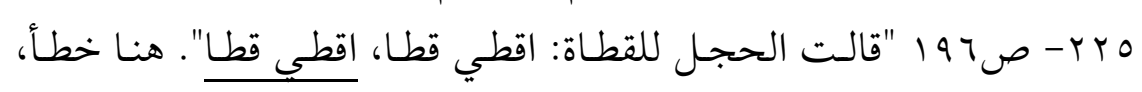

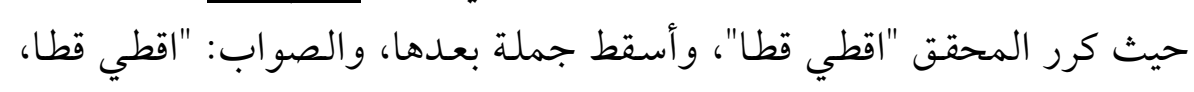
قفاك أمعطا".

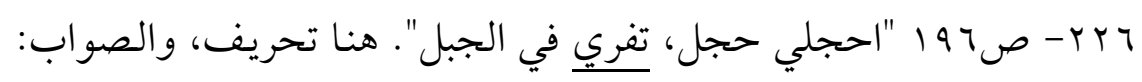

$$
\text { "تنمين في الجبل". }
$$

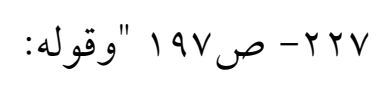

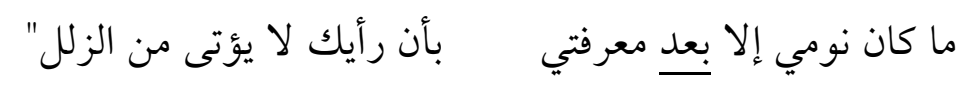

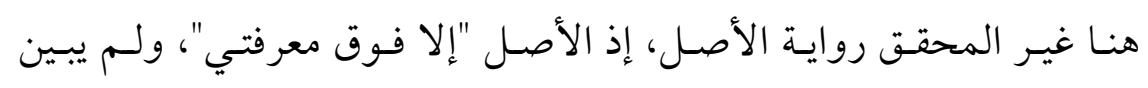

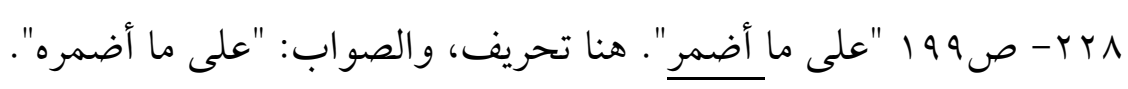

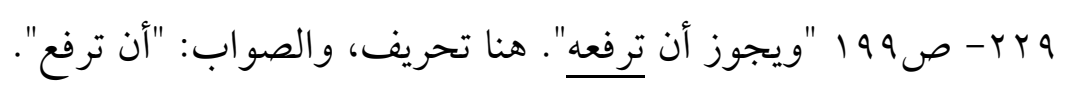




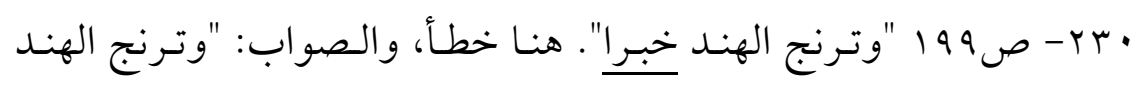
خبره".

ابr - ص · · " "وقد مضى مثل هذا في الكتاب". هنا سقط، والصواب: "في

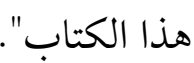

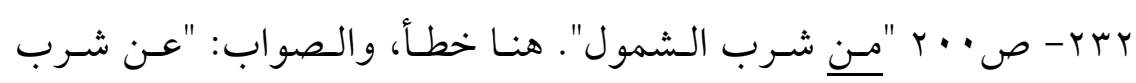

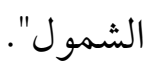

بrץ- ص · • ץ "إذ كان الأترنج لا يشرب". هنا خطأ، و الصواب: "إذ كان

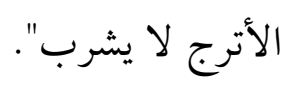

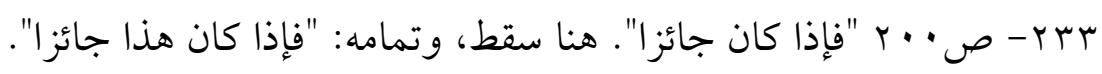
ع ع - ص ا • r "إذ لو تأتى لـه في الوزن". "له" زائدة ليست في الأصل.

氛

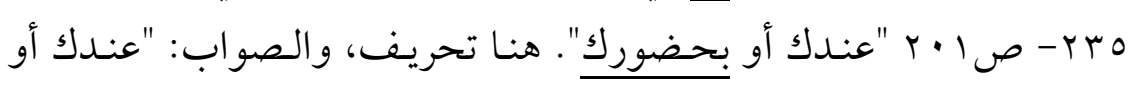
بحضرتك".

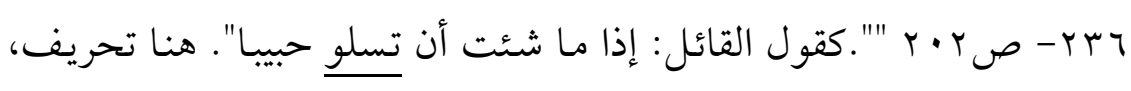

$$
\text { والصواب: " إذا ما شئت أن تسلى حبيبا". }
$$

$r \leq 0$

ك r rV

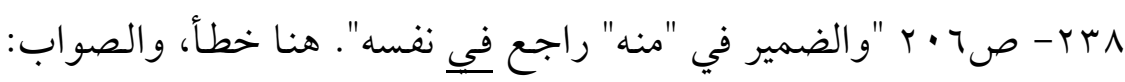

$$
\text { "راجع إلى نفسه". }
$$

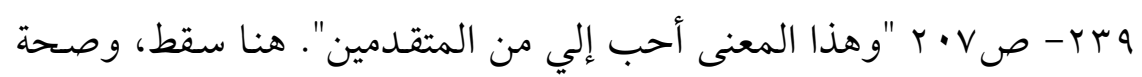

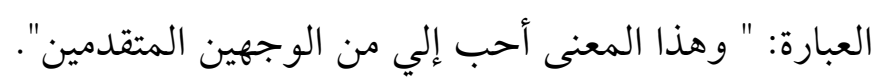

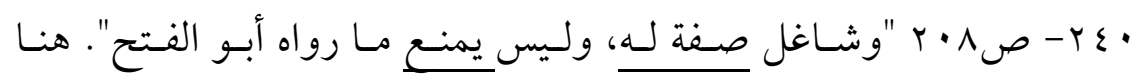
تحريف، والصواب: " وشاغل صفته، وليس يمتنع ما رواه أبو الفتح".

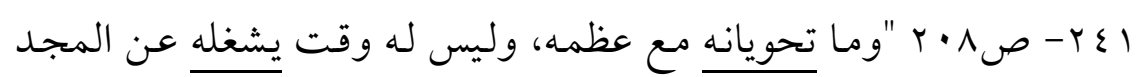

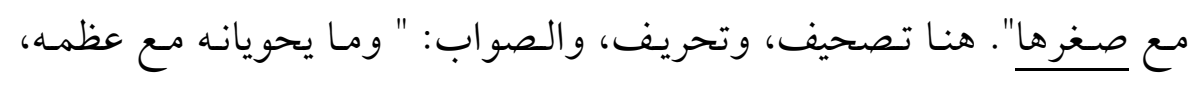
وليس له وقت يشغلها عن المجد مع صغره". 
r צ - - صو • r "كان كأنه أصلُ الإلف". هنا تحريف، والصواب: " كان كأنه

rع r - صو • ب "ولكن أهلك كلهم أهل وفاء". هنا تحريف، والصواب: "

$$
\text { ولكن أهلك كلهم أهلٌ للوفاء". }
$$

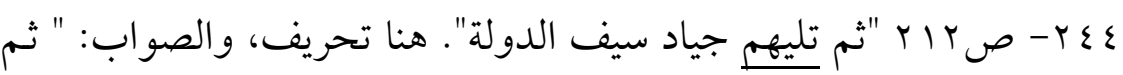

$$
\text { تلتُهم جياد سيف الدولة". }
$$

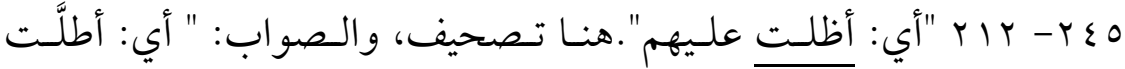

Y צ Y - ص Y I Y "ونفوذ سيف الدولة فيهم". هنا سقط، والصواب: " ونفوذ

مكائد سيف الدولة فيهم".

Y \&V

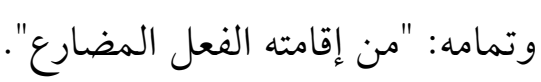

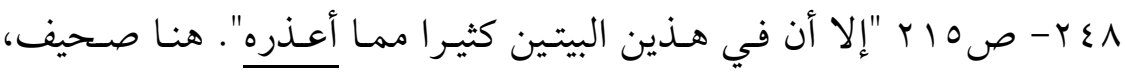

$$
\text { والصواب: "مما أغدره". }
$$

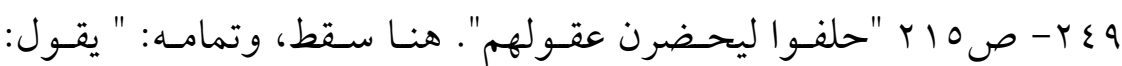

$$
\text { حلفو اليحضرن عقولهم". }
$$

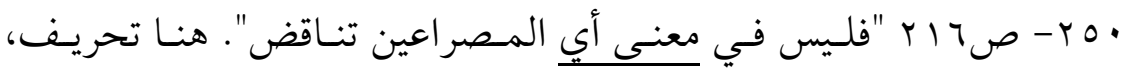

$$
\text { والصواب: "في معنيي المصراعين". }
$$

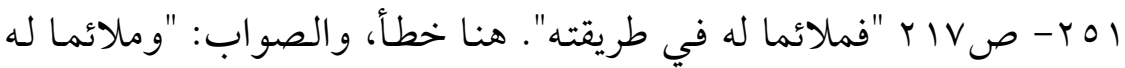

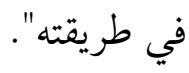

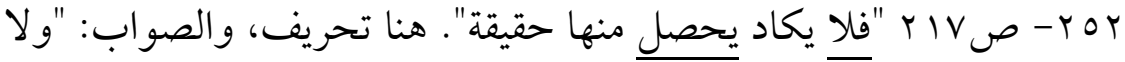

$$
\text { يتحصل منها حقيقة". }
$$

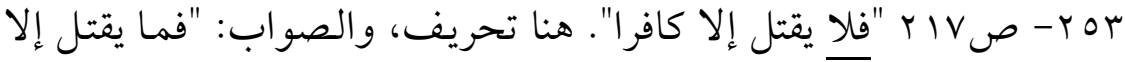




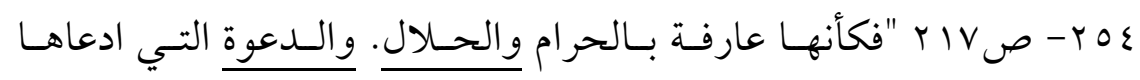

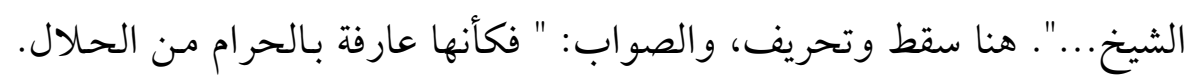
والدعوى التي ادعاها الشيخ...".

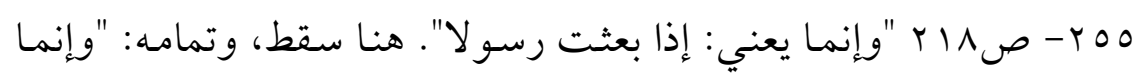

$$
\text { يعني أني إذا بعثت رسو لا" }
$$

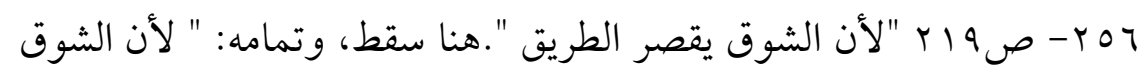

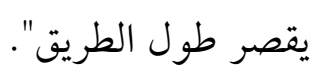

لroV

$$
\text { و الصواب: " وإنما هو تعليل وتطييب لنفس السائل". }
$$

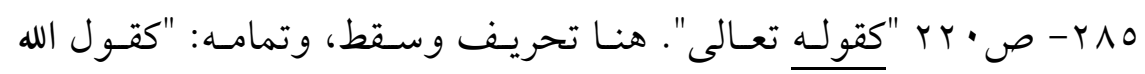

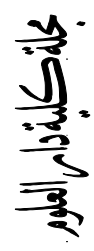

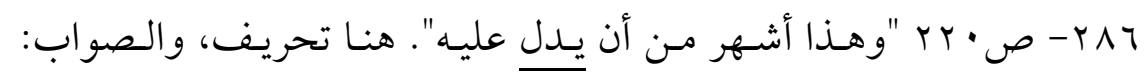
تعالى".

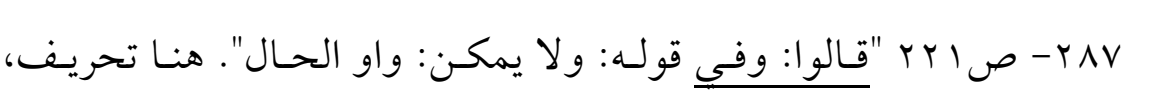

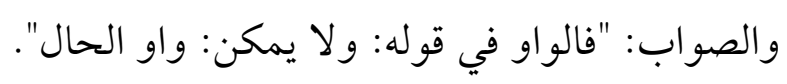

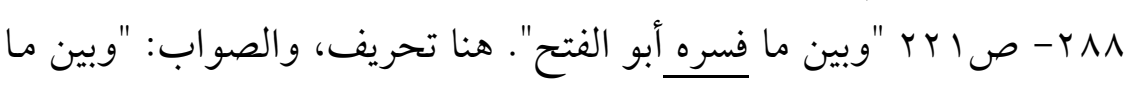

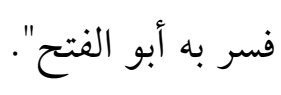

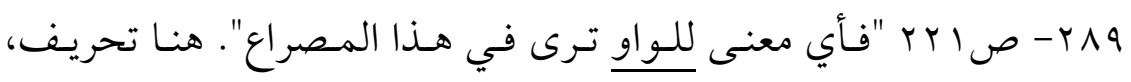

$$
\text { والصواب: "فأي معنى للوُ ترى في هذا المصراع". }
$$

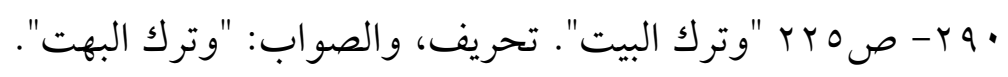

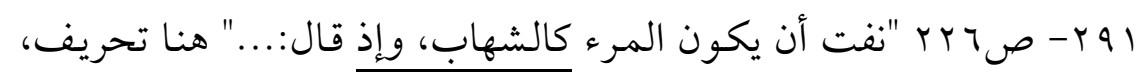

والصواب: " نفت أن يكون المرء إلا كالشهاب، وإذا قال...".

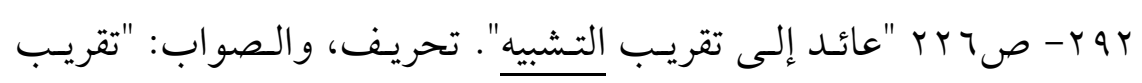

rq r - صر r r "هكذا رؤيته". هنا تحريف، والصواب: " هكذا رويته". 


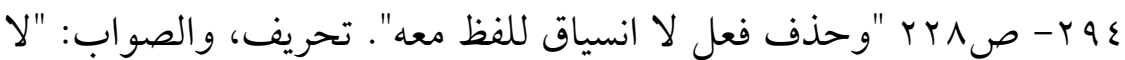

اتساق للفظ معه".

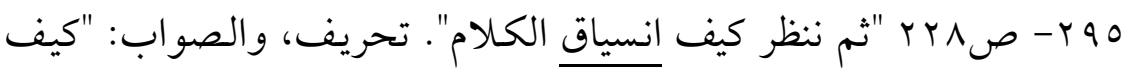

اتساق الكلامم"

צ צ - ص r Y r "وقد قال الصاحب بن عباد". قوله: "ابن عباد" غير موجود

$$
\text { في الأصل. }
$$

Vq ץ - ص זrץ "مـن البـديع المـرذول". تحريـف، والـصواب: "مـن البـديع

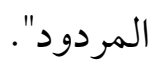

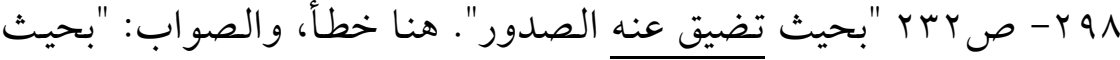

$$
\text { يُضَيِّقُ الصدور". }
$$

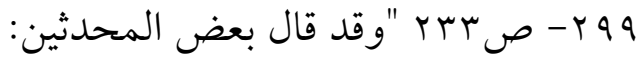

$$
\begin{aligned}
& \text { مطر من العبرات خدي أرضه حتى الصباح ومقلتاي سماؤه" } \\
& \text { هنا تحريف، والصواب: "حتى الصباح ومقلتي سماؤه". }
\end{aligned}
$$

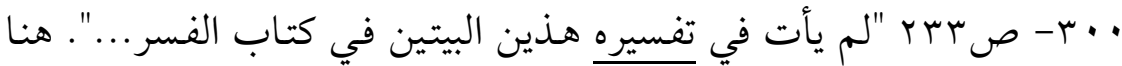

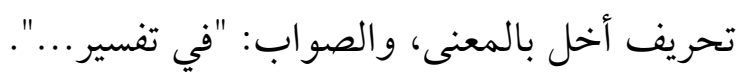

ا • r- ص ع rr "فتزيد غيرة أبي الطيب من شكو اها تحقيقا وتوكيدا. وهذا

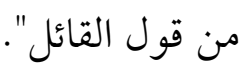

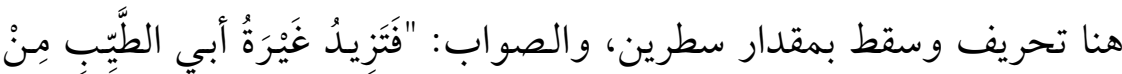

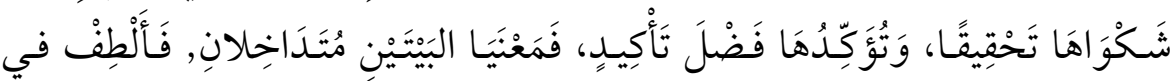

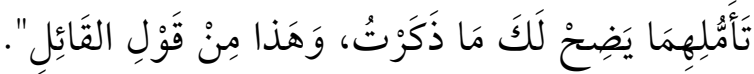

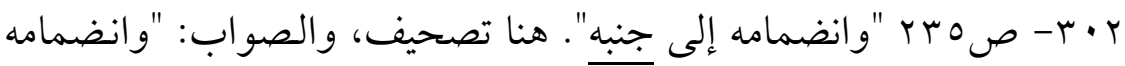

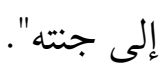

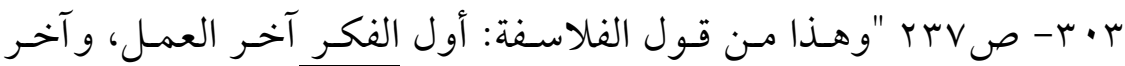
العمـل أول الفكـر". تحريـف في الموضـعين، والـصواب: " أول الفكـرة آخـر العمل، و آخر العمل أول الفكرة". 
ع · r- ص ص r r "وقد قال الشيخ أبو عبدالله النميري". هنا خطأ، والصواب

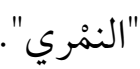

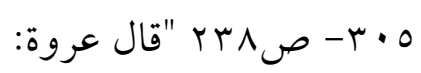

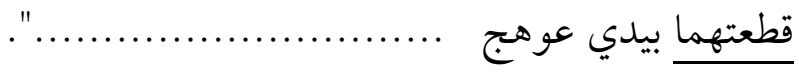

هنا تحريف مقصود من المؤلف، والصواب:" قطعتها بيدي عوهج".

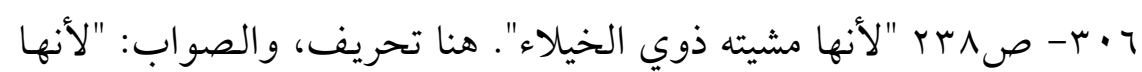
مشية ذوي الخيلاء".

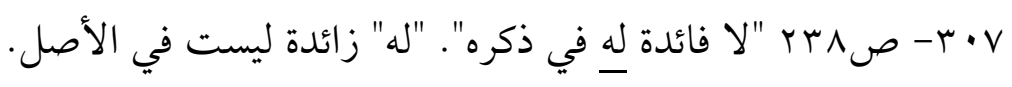

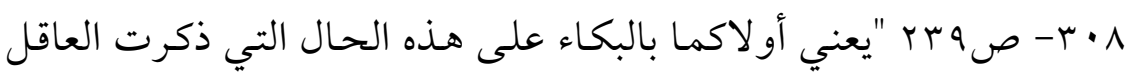

وهو الفؤاد". عنا سقط، والصواب: "التي ذكرت العاقل منكما وهو الفؤاد".

ग

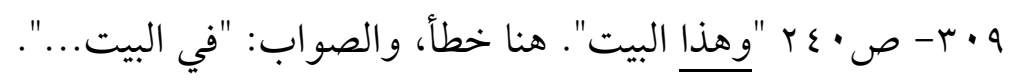

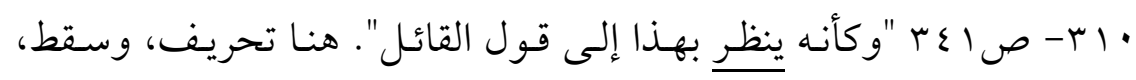
وصحة الجملة: " و كأنه نظر بهذا المعنى إلى قول القائل".

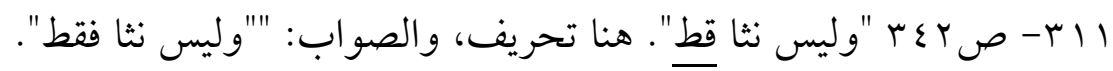
$r \leqslant q$

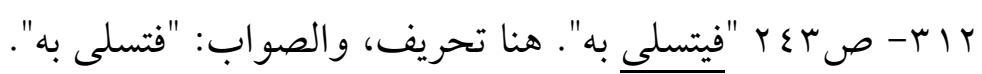

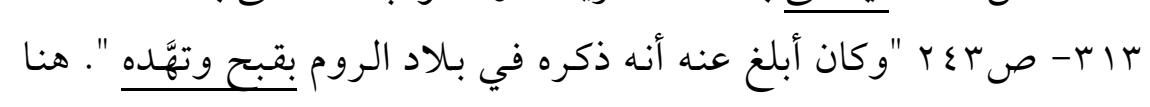$$
\text { تحريف، والصواب: "بقبيح وتهلدهه". }
$$$$
r \varepsilon \varepsilon ص-r \mid \varepsilon
$$

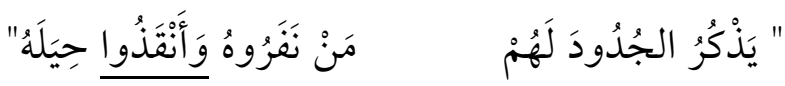
هنا تصحيف في رواية البيت، والصواب: " مَنْ نَفَرُوهُ وَأَنْفَوا حِيَلَهُ".

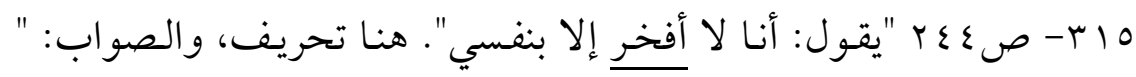

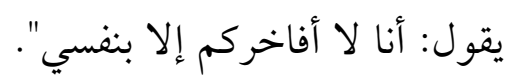

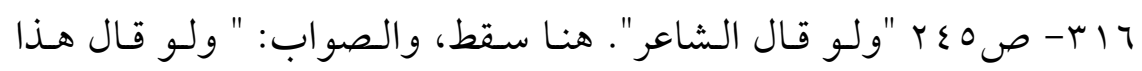




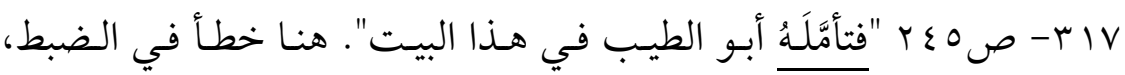

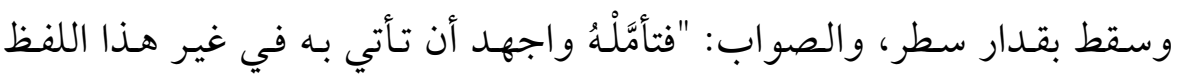

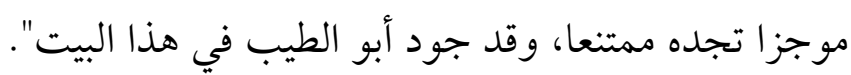

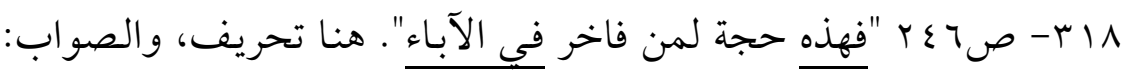
"فهذا حجة لمن فاخر بالآباء".

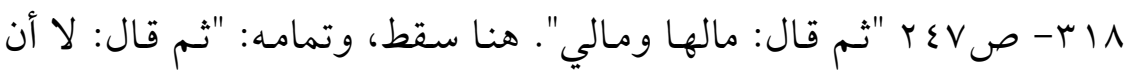
أقول مالها ومالي".

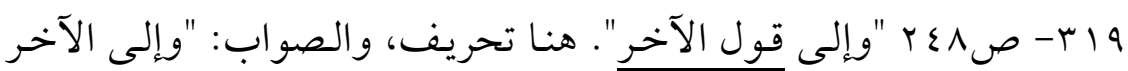

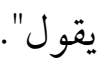

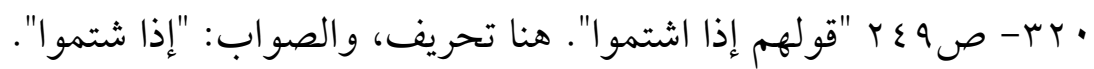

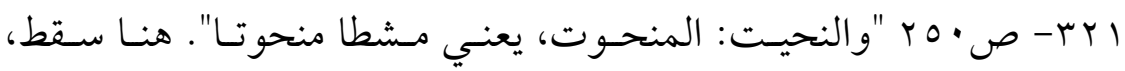
وتمامه: " يعني به مشطا منحوتا".

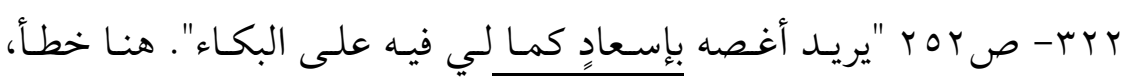

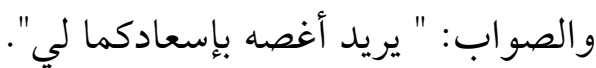

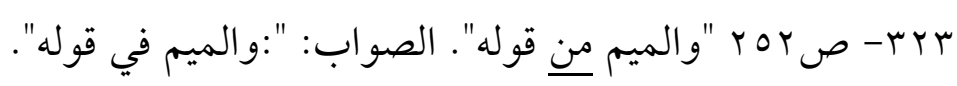

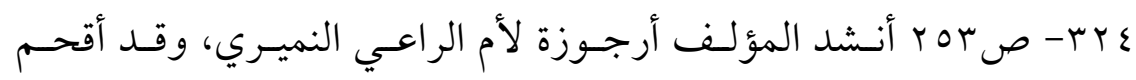
المحقق بيتين لم يذكرهما المؤلف، وهما: "مستنكر ان المس قد تدملكا" لمكات

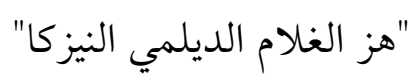
وقد أقحمهما المحقق اعتمادا على مصادر تخريج الأرجوزة، وقد تكرر فعله النها

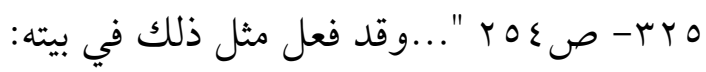

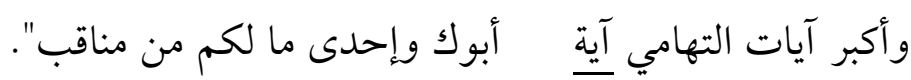
هنا تصحيف، والصواب: " وأكبر آيات التهامي أنَّهُ". 


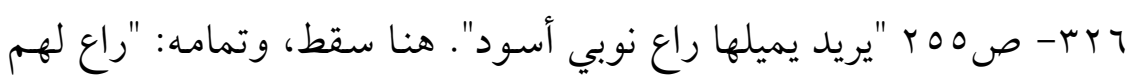

$$
\text { نوبي أسود. }
$$

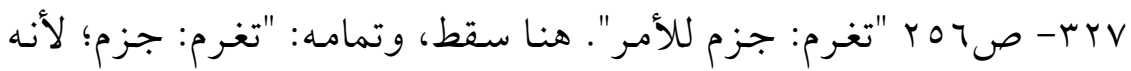

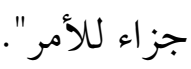

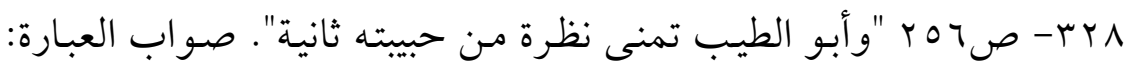

$$
\text { "و أبو الطيب تمنى نظرة من حبيبته". }
$$

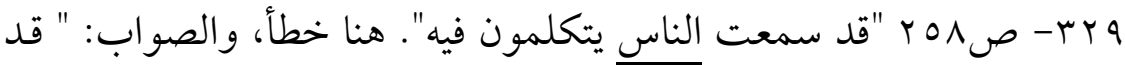

$$
\text { سمعت قوما يتكلمون فيه". }
$$

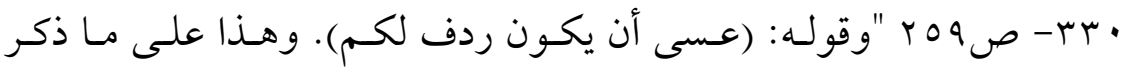
وجـه". هنا سقط، وتمامـه: "وقوله: (عسى أن يكون ردف لكـم)؛ أي: ردفكـم.

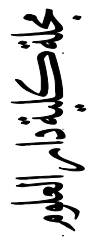

rol

$\overline{3}$
3
0

$$
\text { وهذا على ما ذكر وجه". }
$$

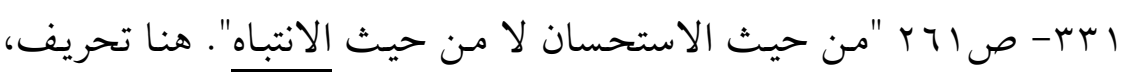

$$
\text { و الصواب: "لا من حيث الاشتباه". }
$$$$
\text { r r r ص ص ب r "قال، يعني المستعين: }
$$

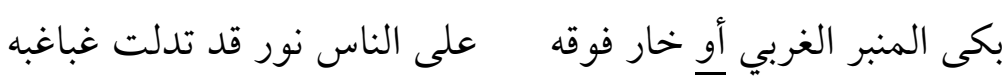

$$
\text { وقوله أيضا: }
$$

$$
\text { والصدق من شيم الكرام فنبنا أمن الشراب تتوب أم من تركه }
$$

وجد بعضهم فنبئن مكتوبا بالألف كحال التنوين".

هنا سقط، وتحريف، والصواب: " قال، يعني به المستعين:

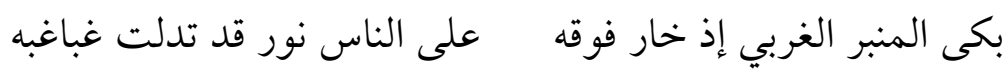

وهذا التصحيف في بيت أبي الطيب يشبه تصحيف بعضهم في قوله أيضا:

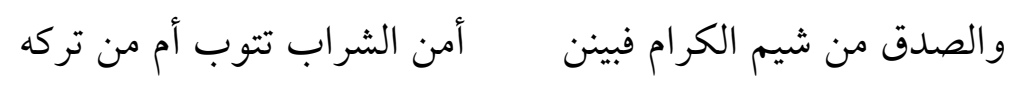

وجد بعضهم فبينن مكتوبا بالألف كالتنوين".

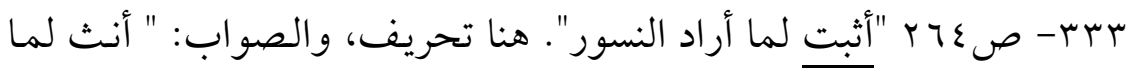




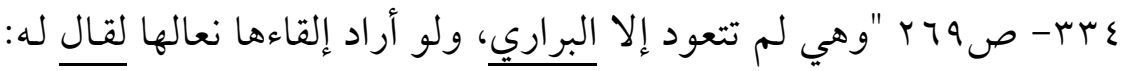

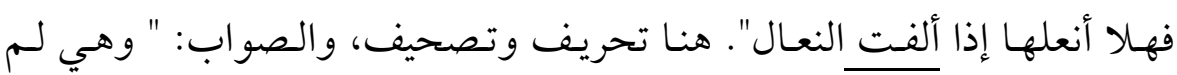

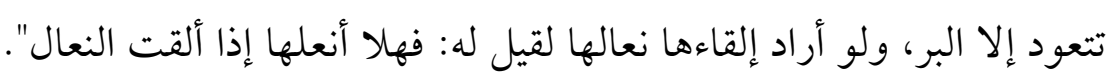

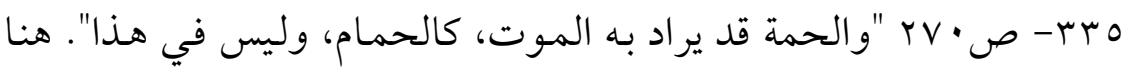
سقط، وتمامه: "وليس في هذا المكان".

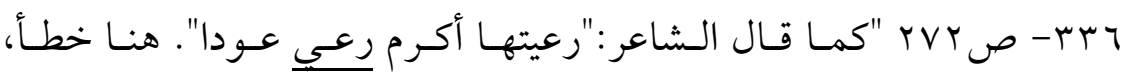
والصواب: " رعيتها أكرم عود عودا".

PrV

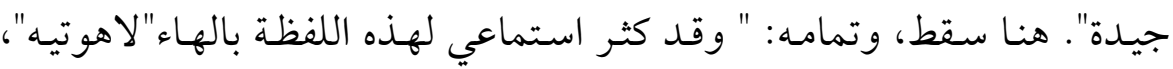
وكلتا الروايتين جيدة".

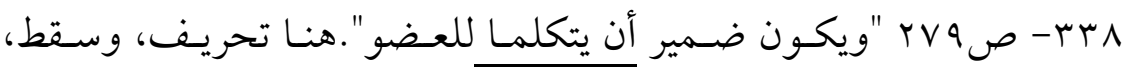

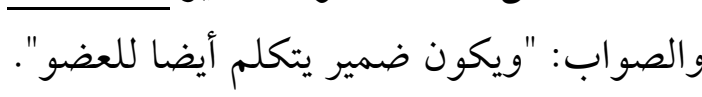

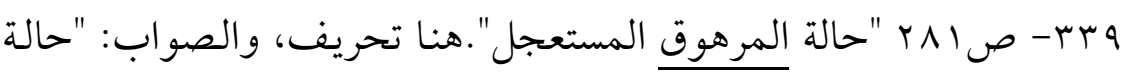

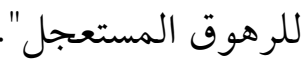

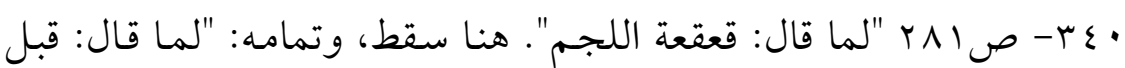

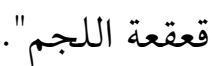

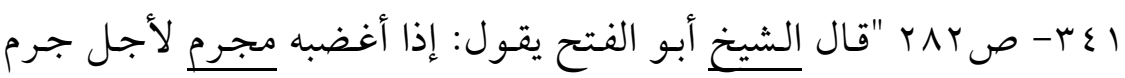

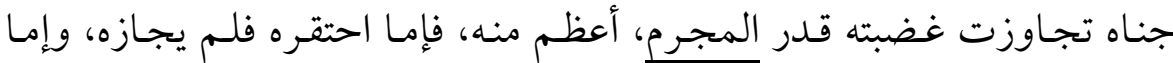

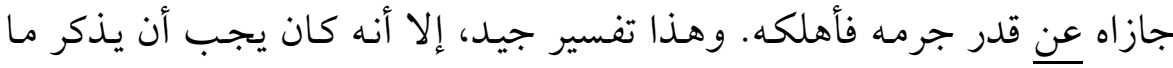

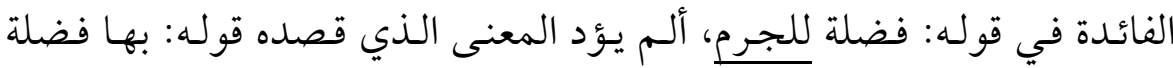
للجرم عن صاحب الجرم حتى قال: مجرم".

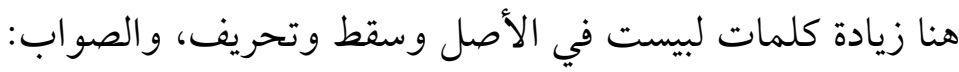

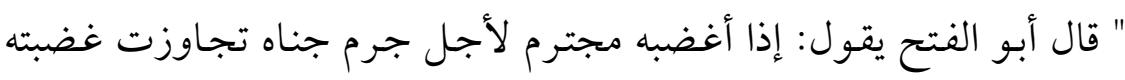

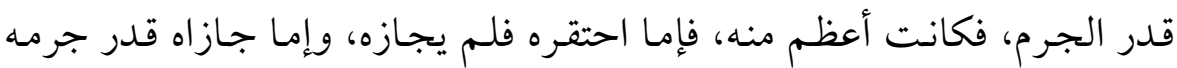

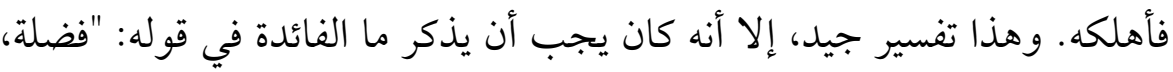


ألم يؤد المعنى الذي قصده قوله: بها فضلة للجرم عن صاحب الجرم حتى قال:

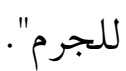

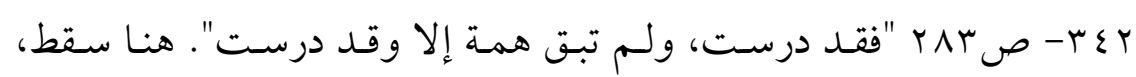

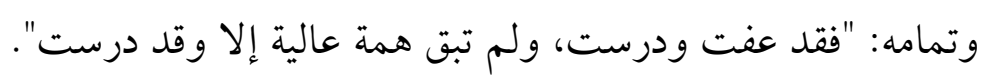

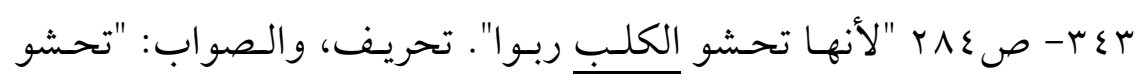

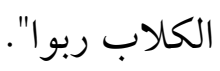

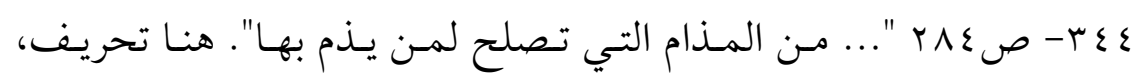
و الصواب: "بأن يذم بها".

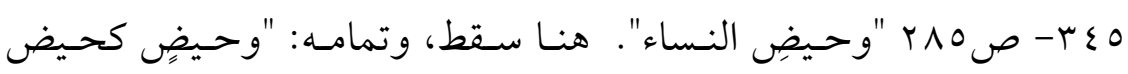

势

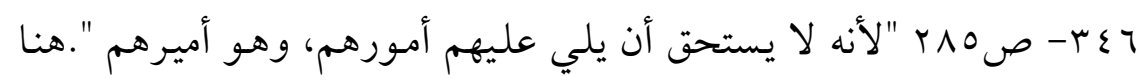

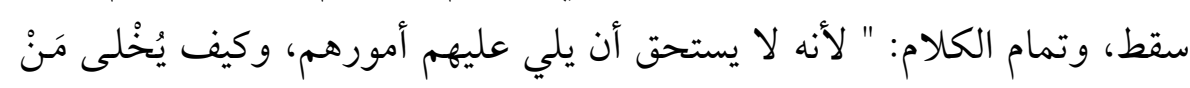

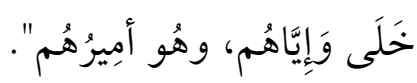

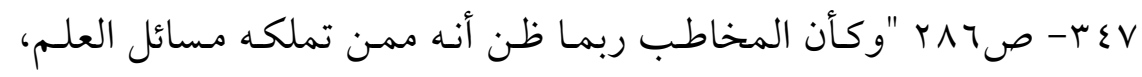

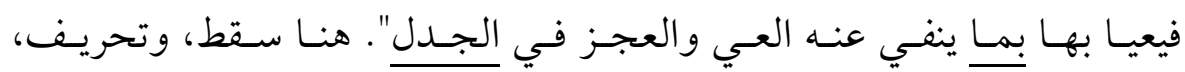

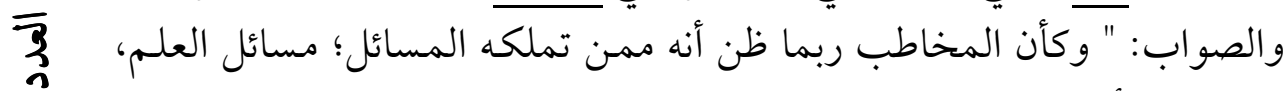

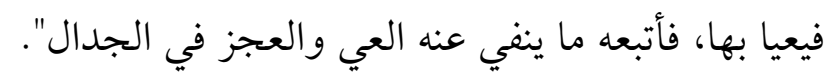

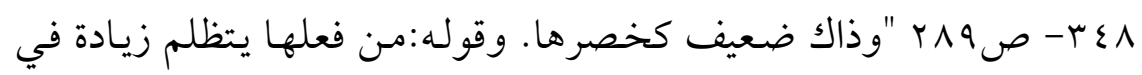

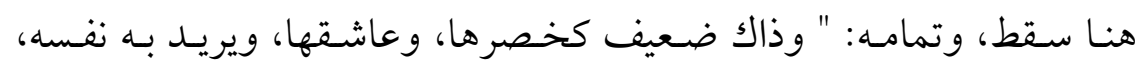

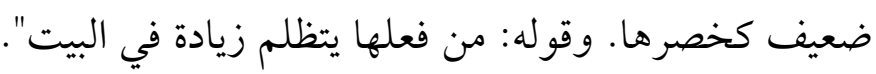

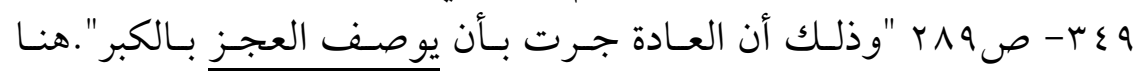

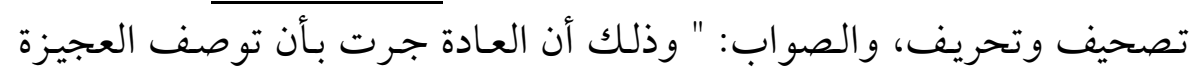

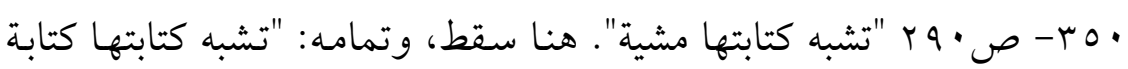

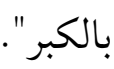




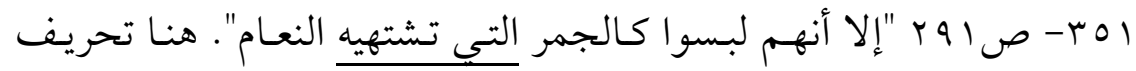

$$
\text { وتصحيف، وصوابه: "الذي يشتهيه النعام". }
$$

Y Y r- ص ع Y "وأرى كثيرا من مسجلي الأدب يتخطون تفسيره. و الهاء في قوله: لو أنها عائدة إلى الراعية".هنا تحريف وزيادة كلمة، و الصواب: " وأرى الصى كثير ا من مسجلي الأدب يتخبَّطون في تفسيره. والهاء في "لو أنها" عائدة إلى إلى

ror إن تحير رجل ركب المفازة فتـاه، وليس الجهل بالدلالة في المفـازة مما يـذم به".هنا سقط، وتصحيف وتحريف، و الصواب: " هذا على ما ذكره. ولكن نزيده وضوحا. إن قال قائل: فما يضير إن تحير رجل ركب المفازة فتاه، وليس الجهل بالدلالة في المفاوز مما يذم به".

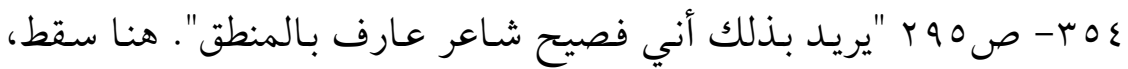

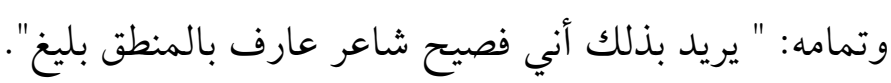

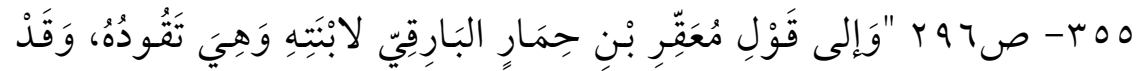

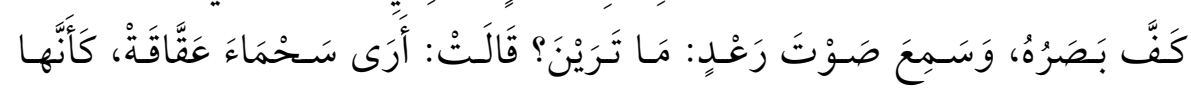

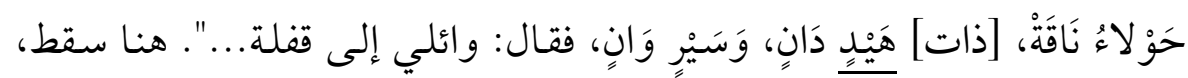

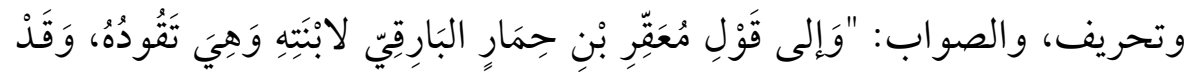

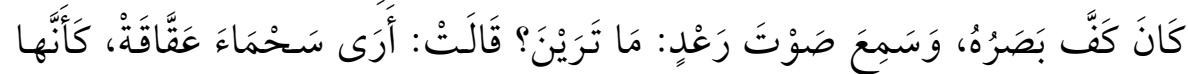

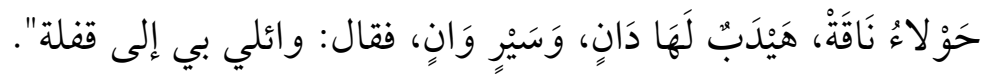

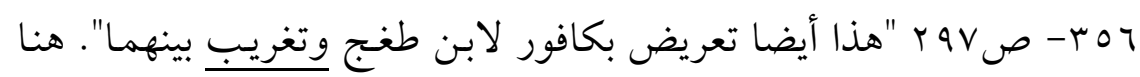
تحريف، والصواب: "وتضريب بينهما". أ roV

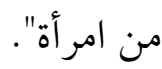

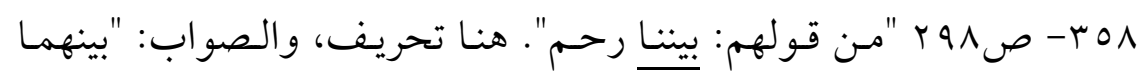




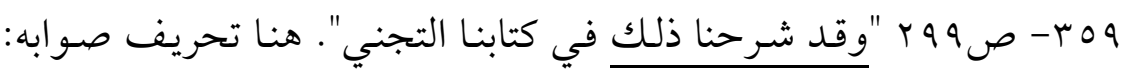

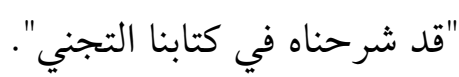

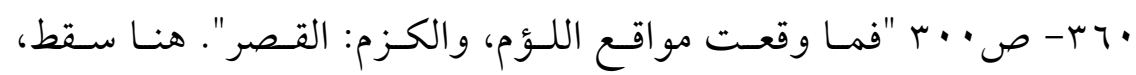
والصواب: " فما وقعت مواقع اللؤم والكزم، والكزم: القصر".

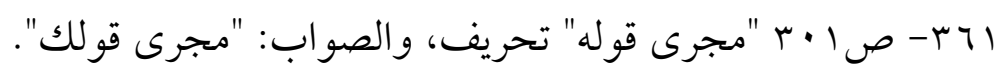
r r r r ثقيلات آذان من الدم والقنا غريقة بحر بالأسنة زاجر" هنا تصحيف، والصواب: " غريقة بحر بالأسنة زاخر".

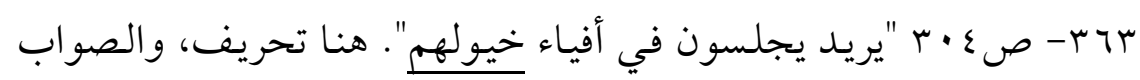
"في أفياء خيلهم".

$\frac{\sqrt{3}}{3}$ ع بr- ص ع • ب "وما سمعنا أحدا روى هذا البيت يتفيؤون". هنا سقط غيَّر المعنى المراد، والصواب: " وما سمعنا أحدا روى هذا البيت إلا يتفيؤون".

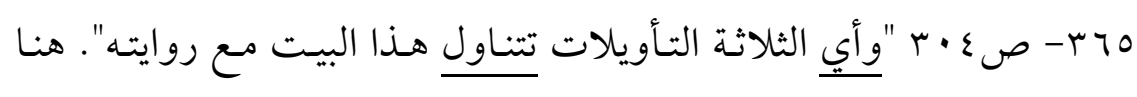
تحريف، والصواب: "أي الثلاثة التأويلات تتأوَّل هذا البيت مع روايته".

YOO

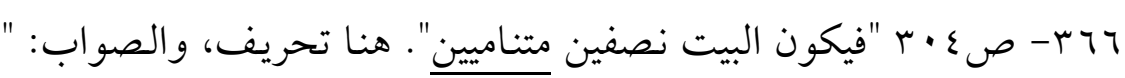
فيكون البيت نصفين متنافيين".

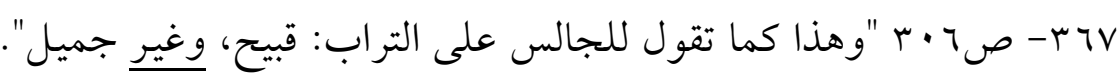
هنا سقط، وتحريف، والصواب: " وهذا كما تقول للجالس على التراب: على لى

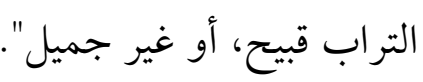

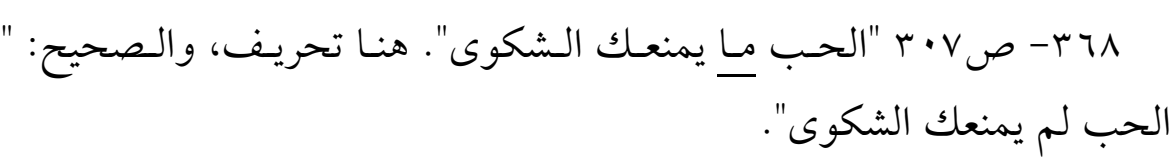
و جr- ص v • r "و قريب منه قول بعض المحدثين". هنا تحريف، و الصواب: "وقريب منه ما قاله بعض المحدثين". • والصواب: "لأنهما في معناها، وليقيم القافية والوزن". 
ו IV- ص • اس "مقام صيانها". هنا تحريف، والصواب: "مقام صيانتها".

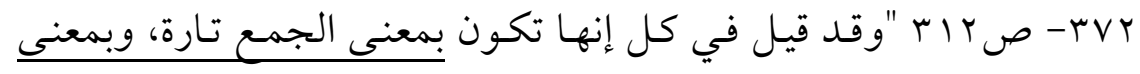
البعض". هنا تحريف وخطاً في القراءة، وصحة العبارة: "وَقَذْ قِيلَ في "كُلِّ" إِنَّهَا

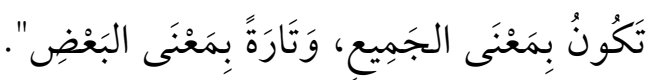

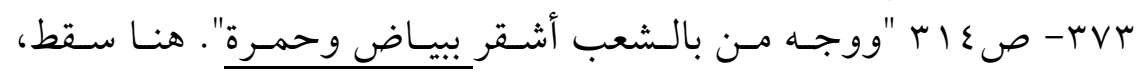
وتحريف، وصحة العبارة: "ووجه من بالشعب أشقر مشرب بياضه حمرة".

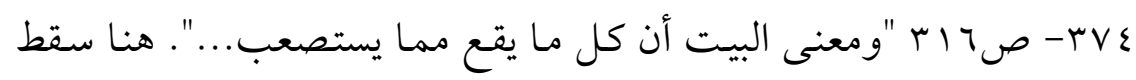

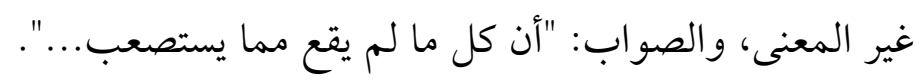

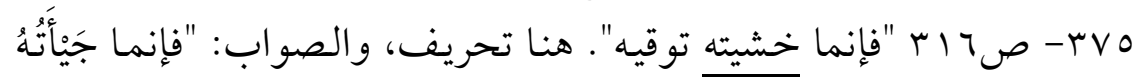
توقيه".

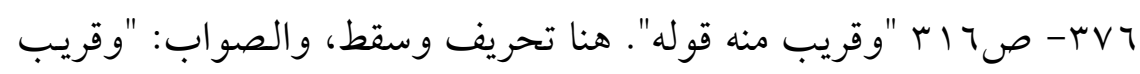

من هV VVV

$$
\text { غير المعنى، والصواب: "على يد غير كافور". }
$$

1. rv

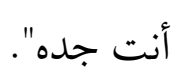

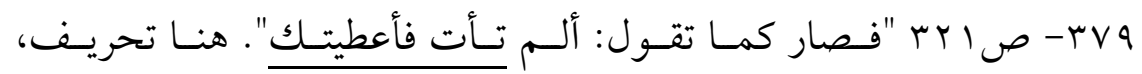
و الصواب: "ألم تأتني فأعطك".

•

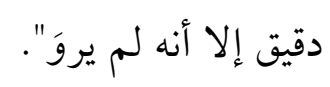

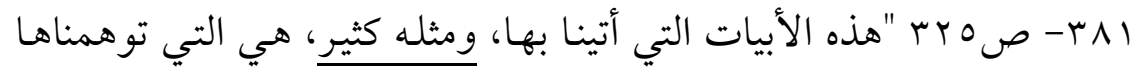

$$
\text { غلقة المعاني". }
$$

قوله: "ومثله كثير" توضـ في أول السطر فهي تابعة لكلام سابق، وصحة

$$
\text { ترتيب الكلام: "ومثله كثير. }
$$

هذه الأبيات التي أتينا بها، هي التي توهمناها غلقة المعاني". 
r Y Y

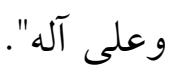

هنا سقط، ويظهر أنه مُتَعَمَّدُ لوروده في المطبوعتين، وهو قوله: "وصحبه

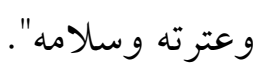

\section{ثُالثا : نقلد الهوامش والتعليقات:}

وقع المؤلف في أوهـام عديـدة في هو امشهه وتعليقاته، حاولـت في هـذا المبحث أن أوضحها وأبين الصواب فيها، وكانت على النحو التالي:

1- ص7 ، هامش ب،، علق على قول المؤلف: "ويثير التراب" بأنها ساقطة

عند الدجيلي

ولي ملحوظتان، أولهما كما سبق وأشرت إليه أن صحة العبارة: "ويثير بينهما

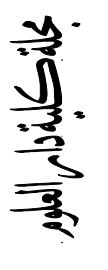

والثانية أن هذه العبارة موجودة في طبعة الدجيلي صفحة: بس.

$$
\text { ץ- صصو، علق على البيتين: }
$$

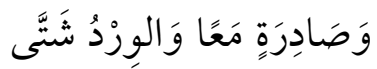

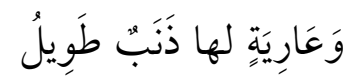

بقوله:"البيتان هما السابع عشر والثامن عشر من تائية عمرو بن قعاس أو قعناس المرادي ...، والقصيدة بمجملها تسير على هذه الشاكلة من الإلغاز ،

$$
\text { وعدتها خمسة وعشرون بيتا". }
$$

وهذا خطأ، إذ أن عدت أبيات هذه القصيدة ثمانية وعشرون بيتا كما في

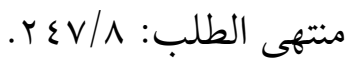

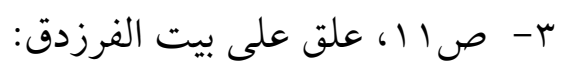

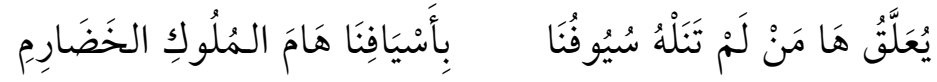

بقوله: "البيت لم أجده في ديوان الفرزدق على كثرة ما له من قصائد على لم

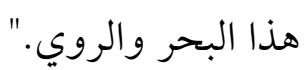

قلت: البيت للفرزدق برواية: 


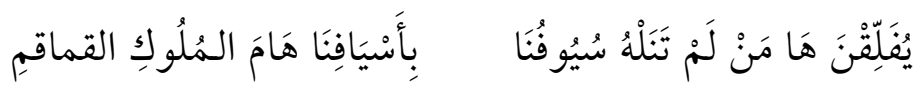

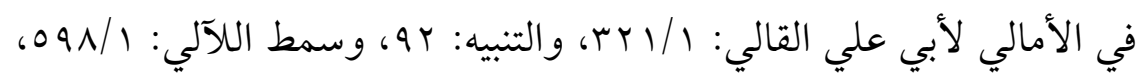

$$
\text { ومجالس العلماء: • •r. }
$$

$$
\text { ع - علق على أبيات بشار التي أولها: }
$$

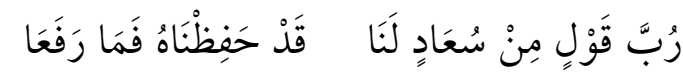

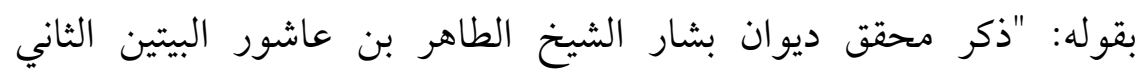

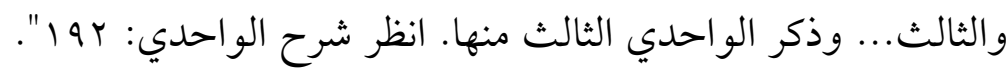

وكان يجب عليه أن يبين أن الواحدي ذكره نقلا عن ابن فورجة.

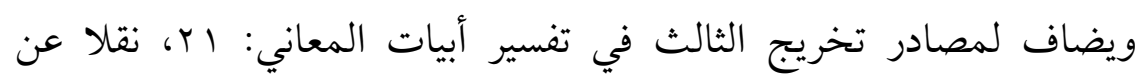

$$
\text { المؤلف أيضا. - ماف }
$$

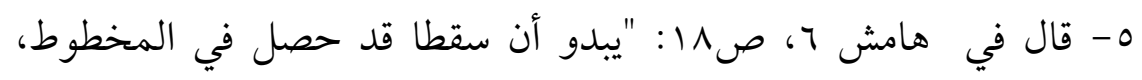

$$
\text { وأشار إليه المحققان". }
$$

قلت: نعم هناك سقط، ولكن كان يجب عليه إكمال السقط من المصادر التي

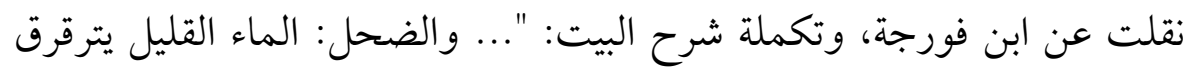

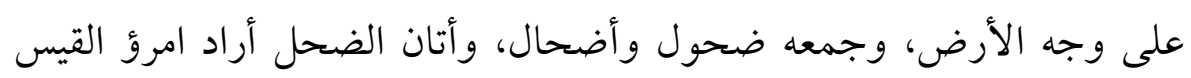

حجارة غيل وارسات بطحلب

$$
\text { والغيل: الماء بين الشجر. ومثله: }
$$

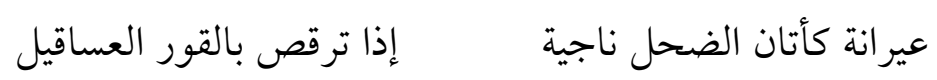

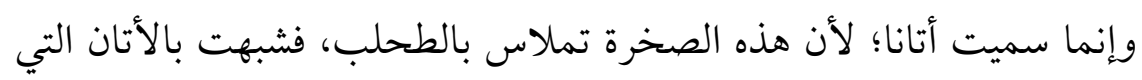

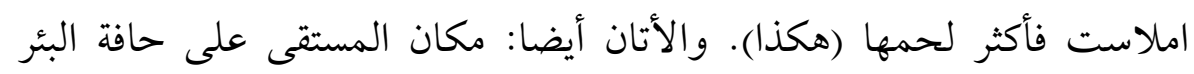

$$
\text { سمي بذلك لامَّلاسه وتراكب الطحلب عليه. }
$$

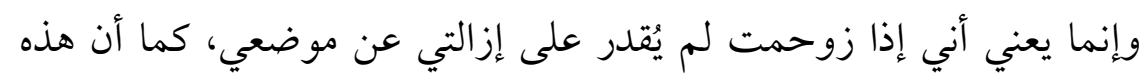

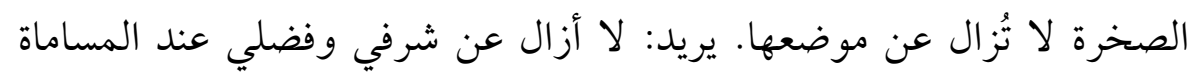

$$
\text { والمفاخرة. أو يعني أني إذا حاربت لم أنهزم. }
$$


وقوله: "فإذا نطقت فإنني الجوزاء" فإن المنجمين يزعمون أن الجوزاء من فئ

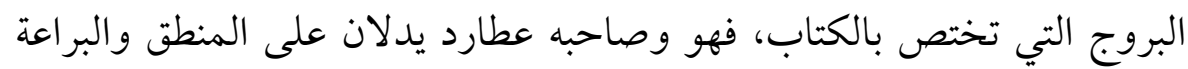

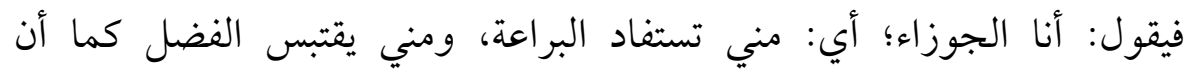

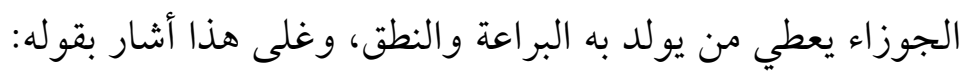

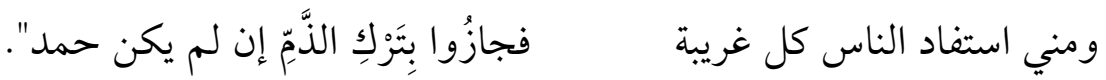

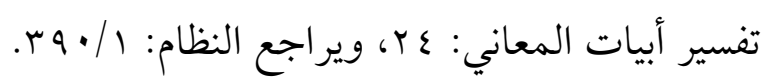

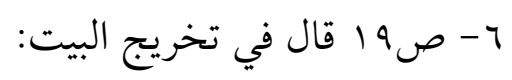

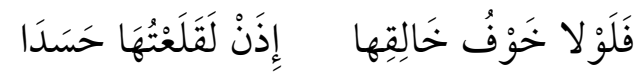
"لم أعثر على قائل البيت".

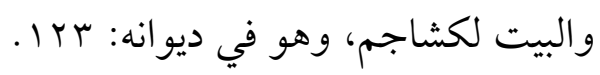

势.

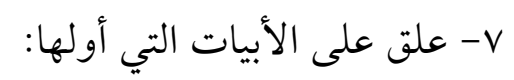

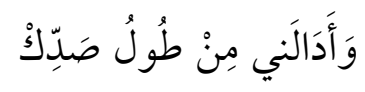

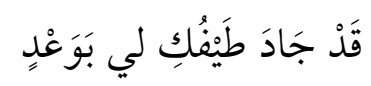

$$
\text { و يقوله: "لم أعثر على هذه الأبيات". }
$$

poq

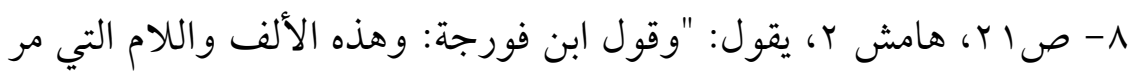

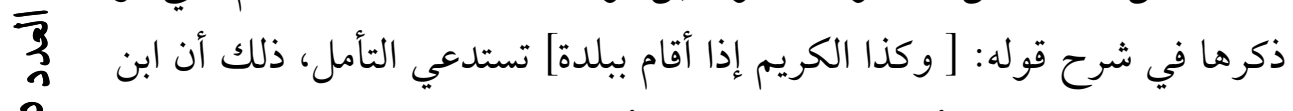

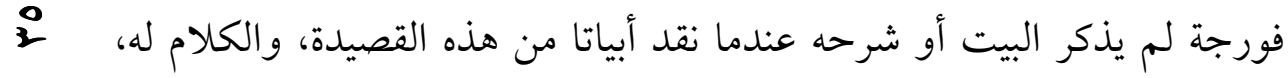
وابن جني أيضا لم يشر إلى ذلك في الفسر أو الفتح الوهبي".

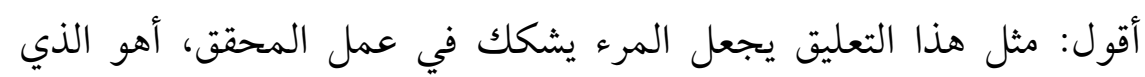

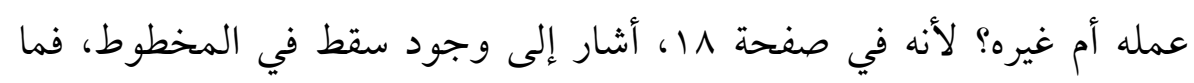

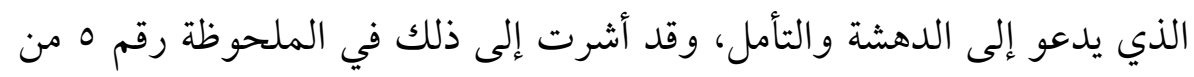

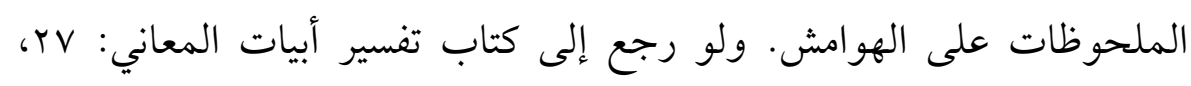

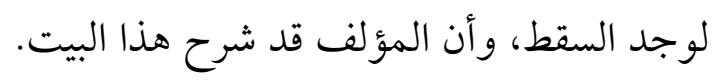

إليَّ صِبَاهُ غَالِبْ لِي بَاطِلُهُ

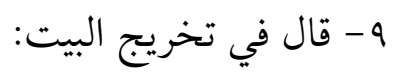

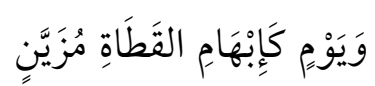




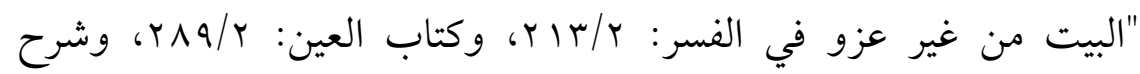

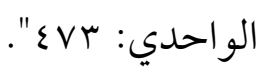

$$
\begin{aligned}
& \text { قلت: البيت لجرير، وهو في ديوانه: ع 97، من قصيدة طويلة. }
\end{aligned}
$$

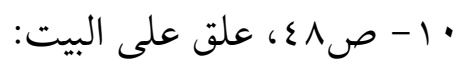

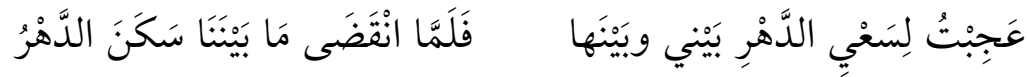

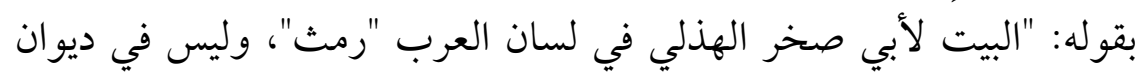

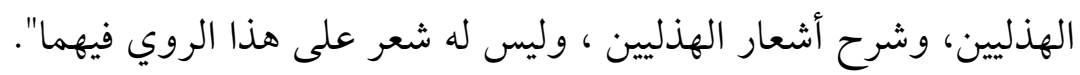

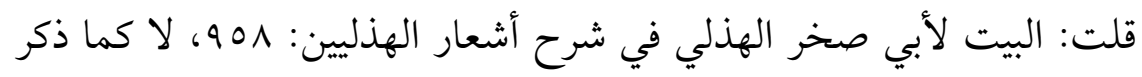
المحقق، وهو من قصيدة طويلة مطلعها:

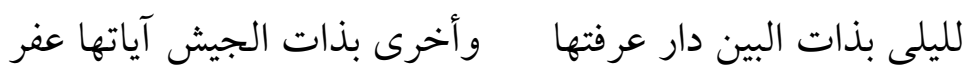
11 - و اده 11

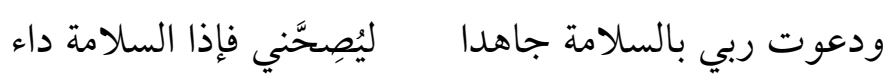

$$
\text { "البيت مع آخر في الصناعتين: می من من دون نسبة". }
$$

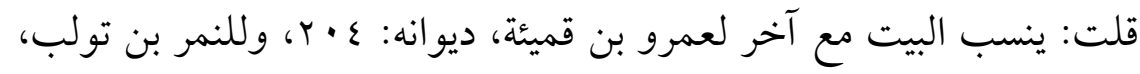

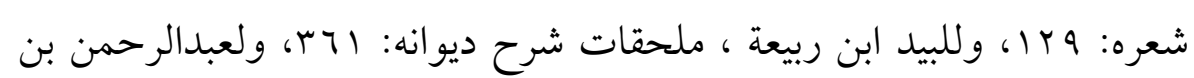

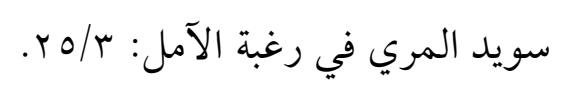
ولمزيد من التخريج تنظر المصادر السابقة.

$$
\text { r ا - ص Vه قال في تخريج البيت: }
$$

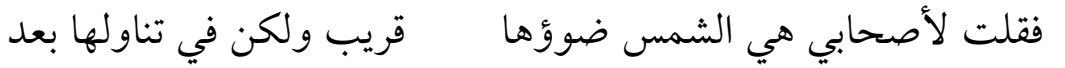

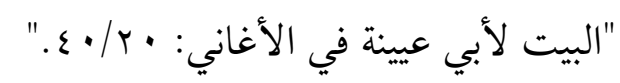

وتكملة اسمه: "أبو عيينة بن محمد بن البئي أبي عيينة المهلبي. "شعر آل أبي

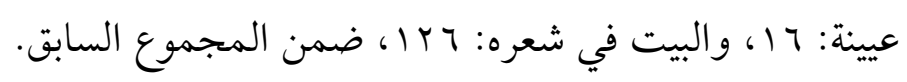

$$
\text { rا - ص VIV، قال في تخريج البيت: }
$$

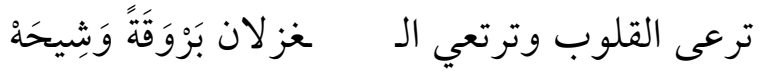

$$
\begin{aligned}
& \text { "البيت من دون نسبة في شرح الواحدي: } 1 \text { • ا". }
\end{aligned}
$$


ويـضاف للمـصدر السـابق: تفسير أبيـات المعـاني: Vل، ونفحـة الريحانـة:

$$
r \cdot / 1
$$

$$
\text { ع ا - ص979، هامش 1، ذكر أنه لم يجد البيت: }
$$

ألمي بعراف النقا وتيمَّني مهب النعامى واجعلي الليل مرودا

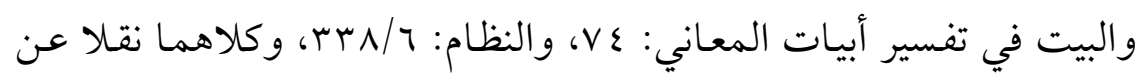

$$
\text { المؤلف. }
$$

$$
\text { 10 - ص ·V، قال في تخريج البيت: }
$$

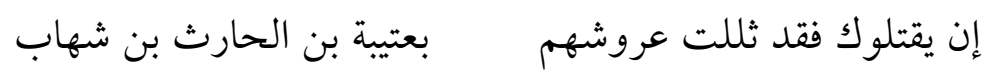

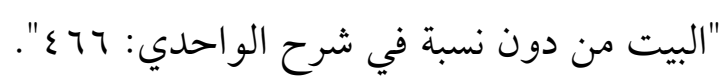

قلت: البيت لربيّعة بن عبيد بن سعد بن جذيمة من بني قعين. الحماسة لأبي

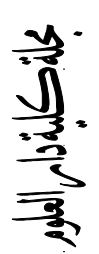

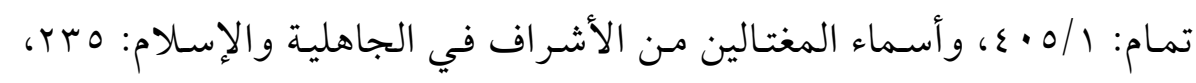

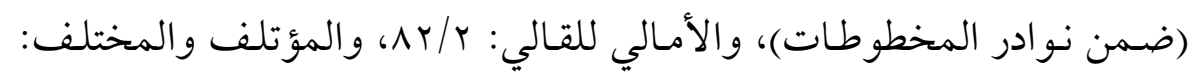

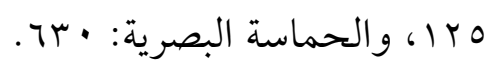

$$
\begin{aligned}
& 17
\end{aligned}
$$

Y4

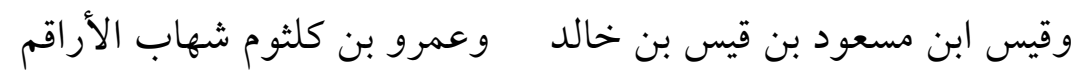

亨

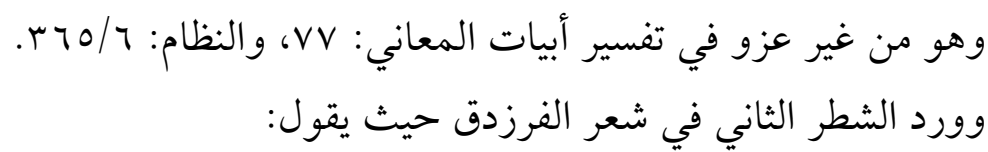

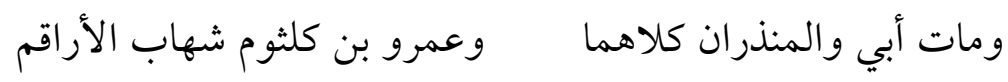

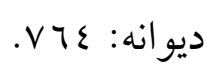

$$
\text { ا ا - لم يخرج بيتي الرجز }
$$

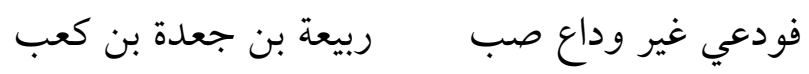

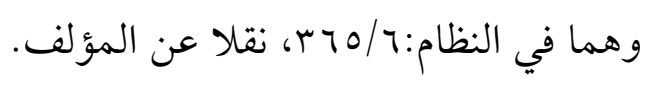

11 - صل صT، لم يخرج بيتي عمار الكلبي:

بانت نعيمة والدنيا مفرقة وحال من دونها غير ان مزعوج 
تسد ما بين حاذيها بذي خصل كالبرد نصفان؛ هداب ومنسوج وهما في النظام: / ع و ب، نقلا عن المؤلف، والأول منهما في معجم الأدباء:

$$
\text { 19 - ص •^، قال في تخريج البيت: }
$$

وإذا دعوا لنزال يوم كريهة سدوا شعاع الشمس بالفرسان

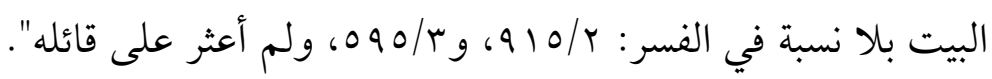

قلت: البيت لأمية بـن أبي الصلت، أو لابنه القاسم، أمية بن أبي الصلت

$$
\text { حياته وشعره: }
$$

• •

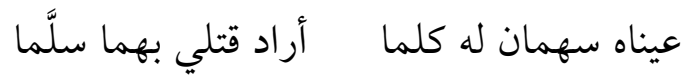

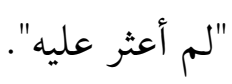

وينسب البيت للخليل بن أحمد، وهو في مجموع شعره: ه०ه (ضمن شعراء

$$
\text { مقلون)، وينسب أيضا لأبي العتاهية، وهو في ديوانه: ب^^؟. }
$$

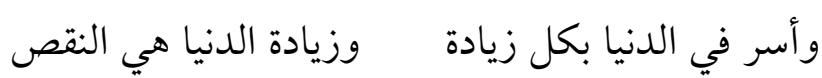

$$
\text { "البيت من دون نسبة في الوساطة: وبr". }
$$

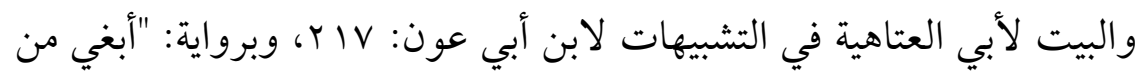

الدنيا زيادتها" في ديوانه: 99 19.

$$
\text { r r - صی^• 1، قال في تخريج البيت: }
$$

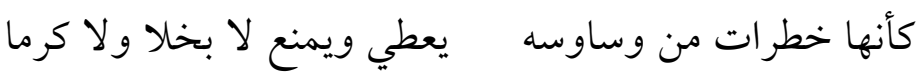

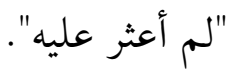

والبيـت لأبسي بكـر الخـوارزمي، ديوانه: · اعـ، وينسب أيسضا لأبي القاسـم

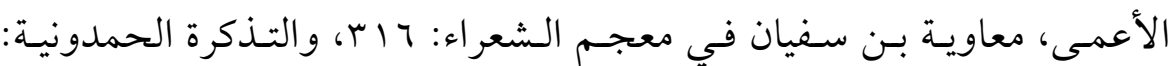

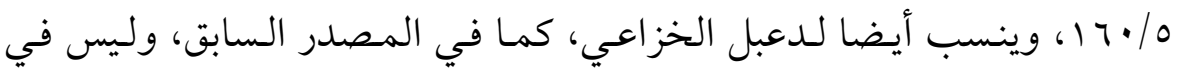




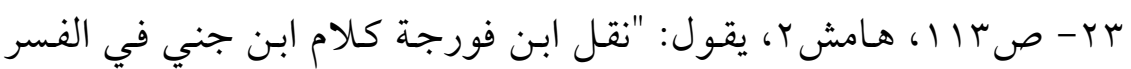

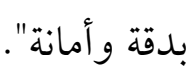

ولي ملحوظتان؛ أولهما أن المحقق أكثر مـن الهوامش التي يذكر فيها أن

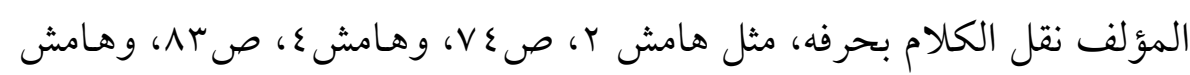

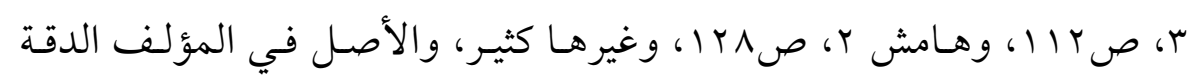

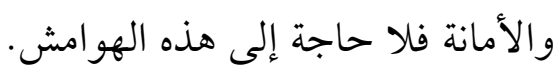

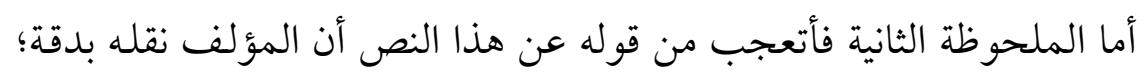

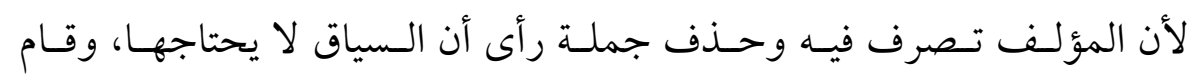

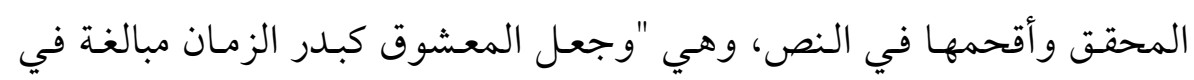
حسنه".

势 r4T

$\overline{3}$
$\vdots$
0

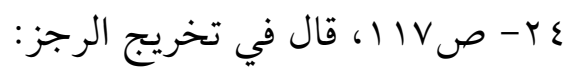

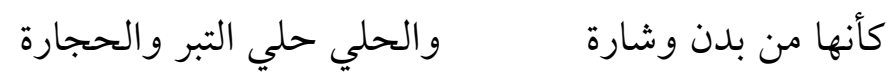

$$
\begin{aligned}
& \text { مدفع مشاء إلى قرارن } \\
& \text { والمخصص: ع/•• ". }
\end{aligned}
$$

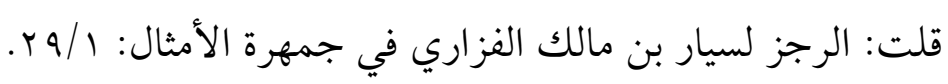

$$
\begin{aligned}
& \text { Or }
\end{aligned}
$$

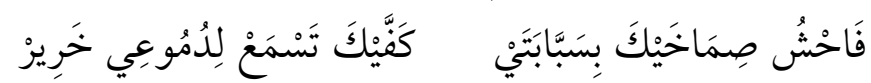

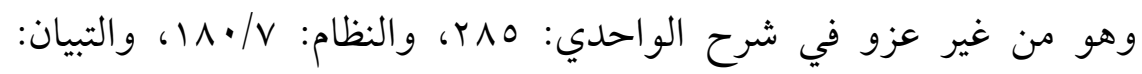

$$
\begin{aligned}
& \text {. } 1 \varepsilon q / r
\end{aligned}
$$

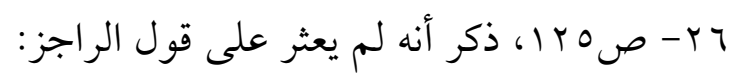

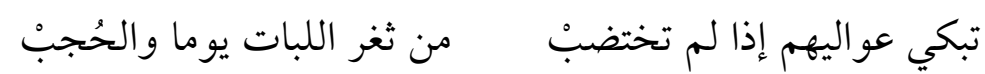

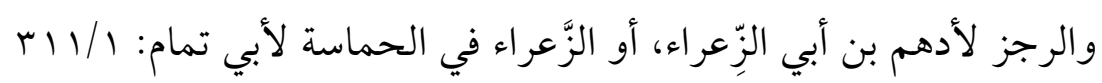

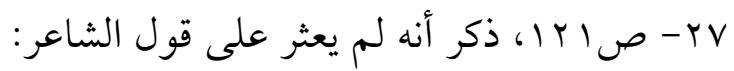

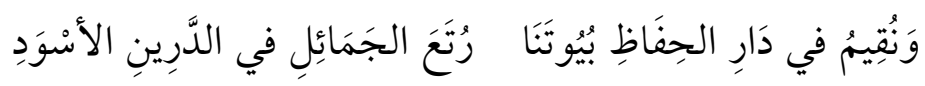




$$
\begin{aligned}
& \text { و البيت لمضرس بن ربعي في الحماسة لأبي تمام: 1/1 • آ. }
\end{aligned}
$$

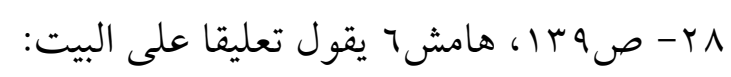

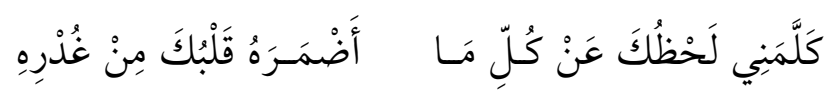

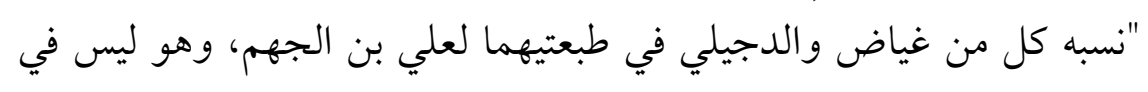

$$
\text { ديوانه". }
$$

وأقول: الذي نسب البيت لعلي بن الجهم المؤلف نفسه، حيث سبقه بقوله:

$$
\begin{aligned}
& \text { "... و إنما هذا البيت كقول علي بن الجهم".!".. }
\end{aligned}
$$

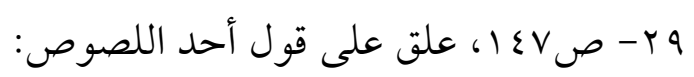

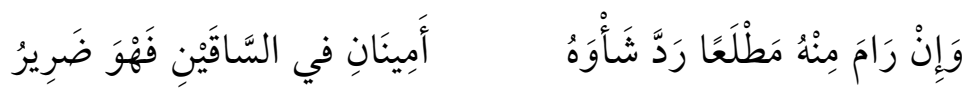

بقوله: "لم أعثر عليه، وقد تتبعت هذا الروي فيما وصلنا من أشعار

$$
\text { اللصوص فلم أجد هذا البيت". }
$$

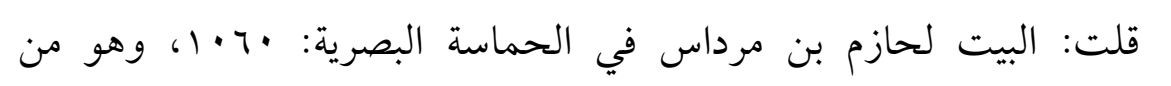

$$
\begin{aligned}
& \text { مصادر المحقق. } \\
& \text { • r- ص مor or، ذكر أنه لم يعثر على قول الشاعر: }
\end{aligned}
$$

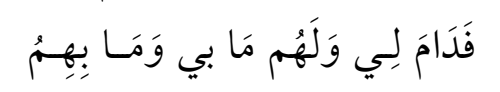

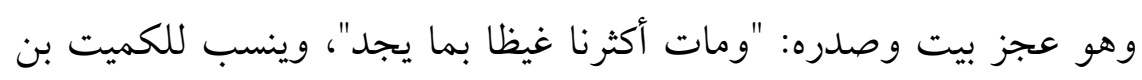

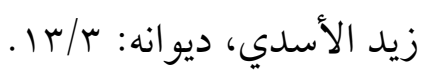

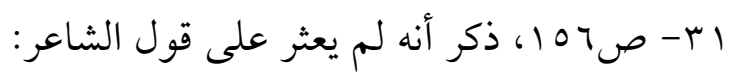

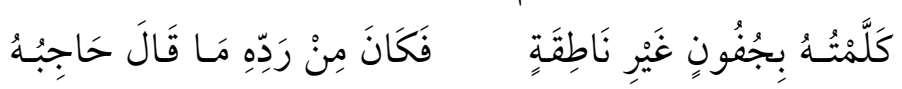

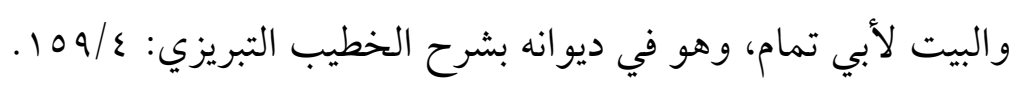

$$
\text { r r- ص بr 1، ذكر أنه لم يعثر على البيت: }
$$

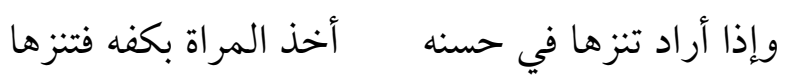

قلت: ليوسف بن هارون الرمادي بيت قريب من هذا، وهو قوله:

وإذا أراد تنزها في روضة أخذ المراة بكفه فأدارها 


$$
\begin{aligned}
& \text { rr- صع آ 1، قال في تخريج البيت: }
\end{aligned}
$$

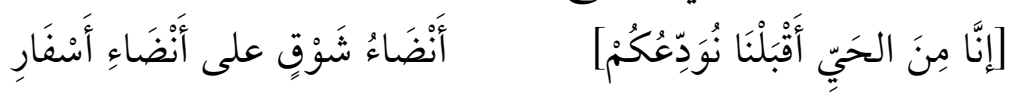

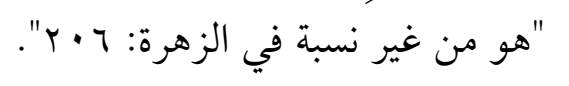

$$
\begin{aligned}
& \text { قلت: البيت للعباس بن الأحنف، وهو في ديو انه: • VI أ. }
\end{aligned}
$$

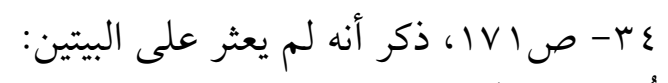

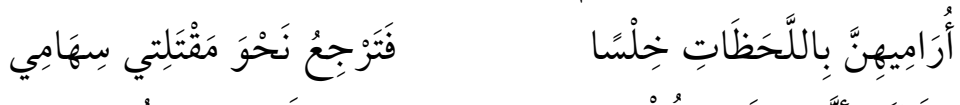

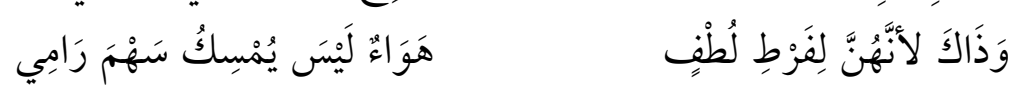

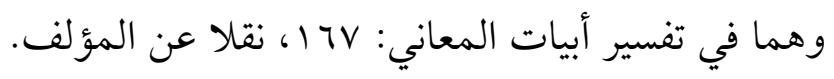

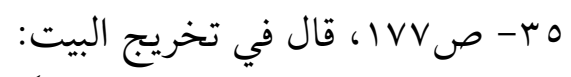

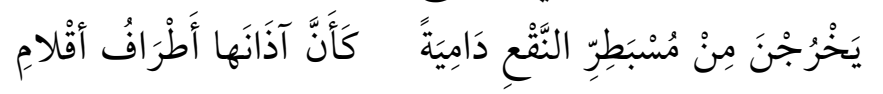

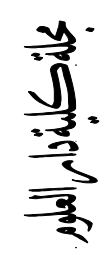

$$
\begin{aligned}
& \text { "البيت لجرير في العمدة: // / عـ، وليس في ديوانه، وبلا نسبة في الفسر: }
\end{aligned}
$$

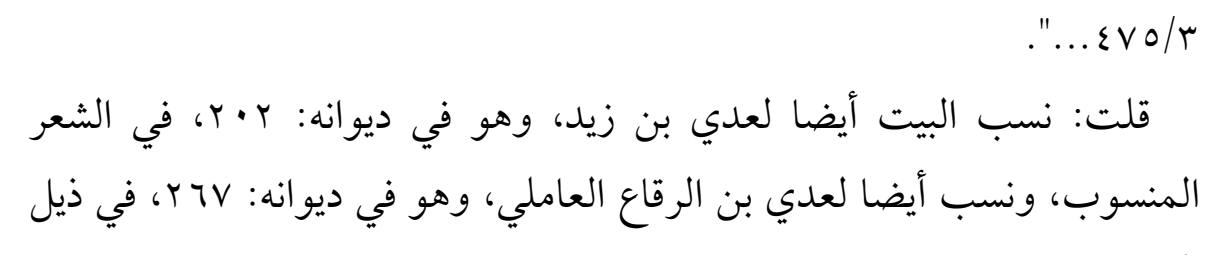

Y7o

$\overline{3}$
3
1

$$
\text { جr- صـ110، قال في تخريج البيتين: }
$$

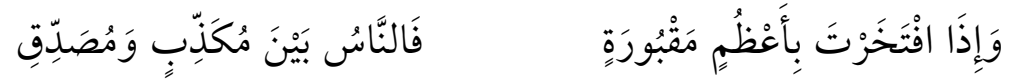

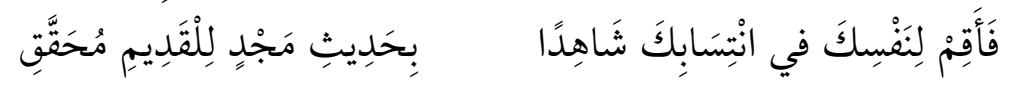
"البيتان في شرح الواحدي: ب rع، ولعله أخذهما عن ابن فورجة".

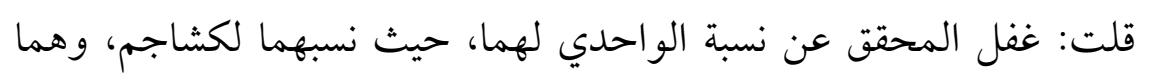

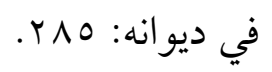

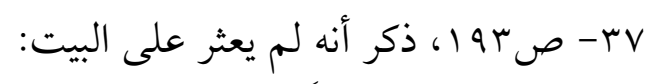

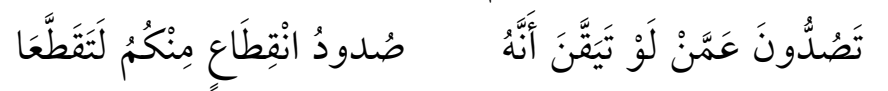

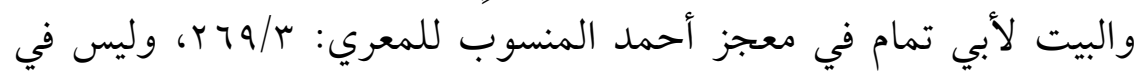

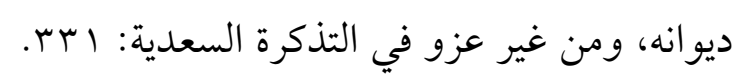




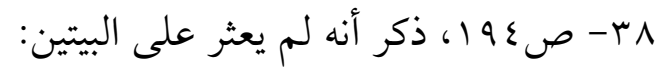

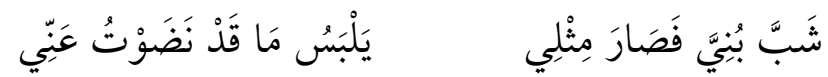

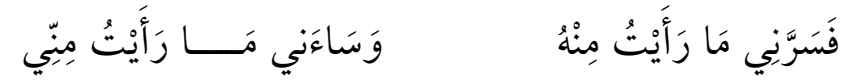

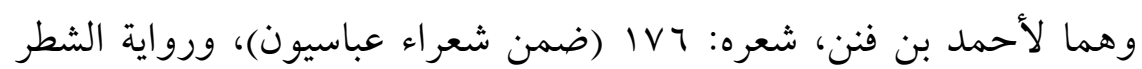

$$
\text { الأول من البيت الأول: "عاش بني فصار مثلي". }
$$

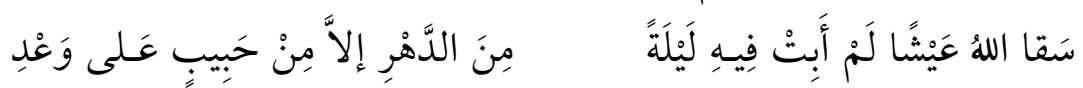

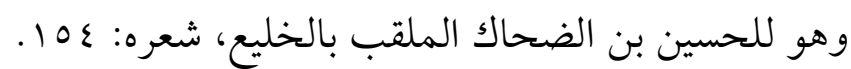

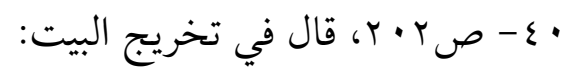

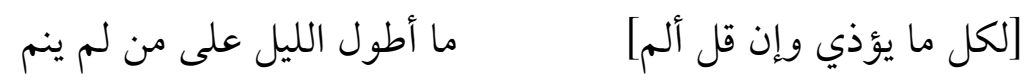

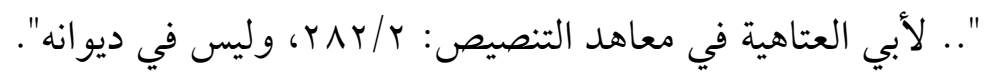

قلت: البيت من أرجوزته الشهيرة المعروفة بذات الأمثال، وهي في ديوانه:

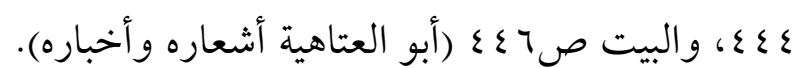

$$
\text { إ) }
$$

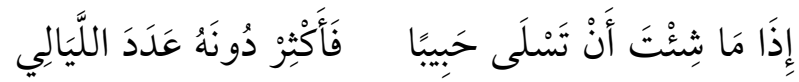

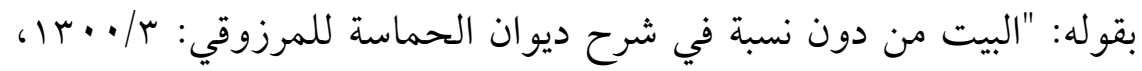

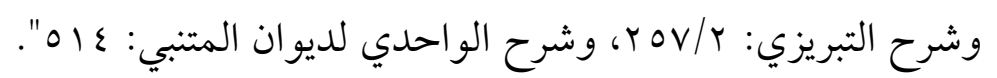

$\frac{\sqrt{3}}{\frac{3}{3}}$

rาT

قلت: البيت لزهير بن جناب الكلبي، وهو في ديوانه: بوهو

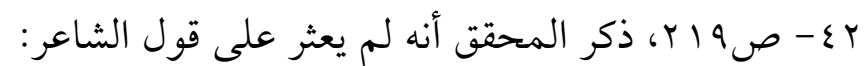

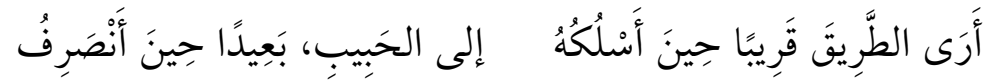

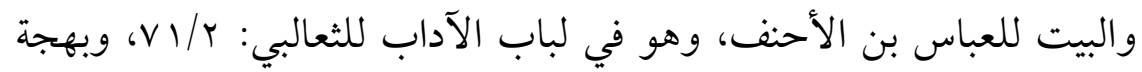

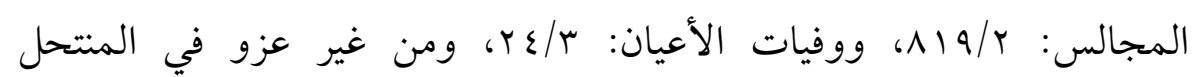

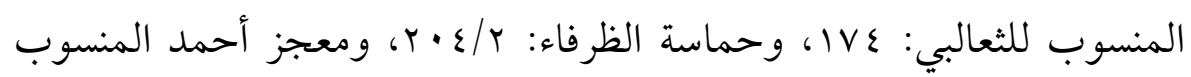

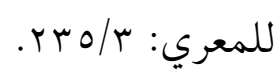

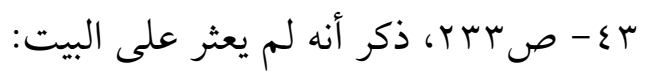




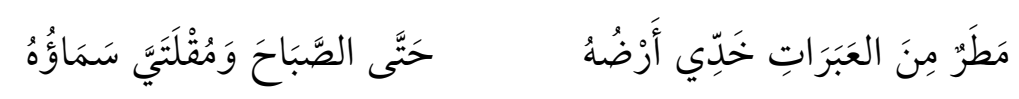

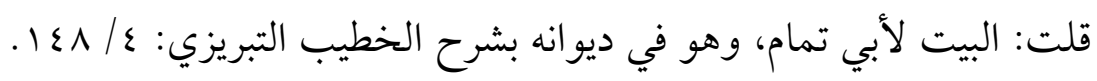

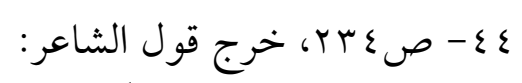

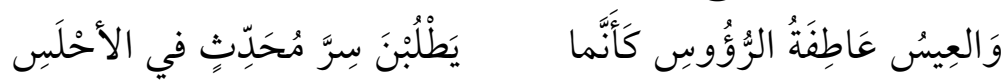

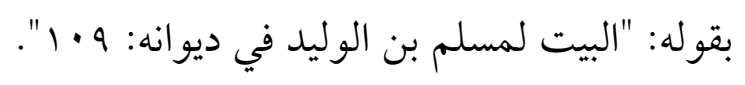

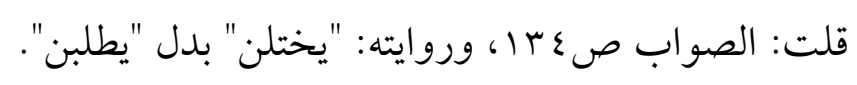

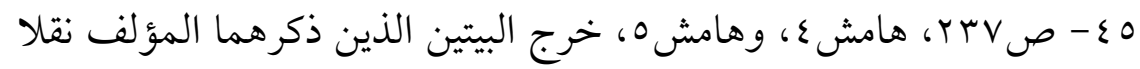

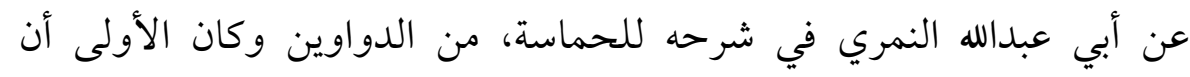

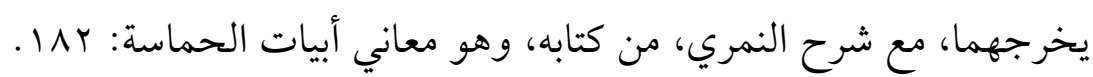

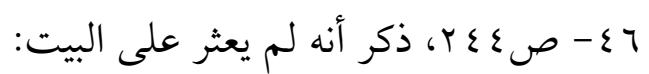

誉.

rIV

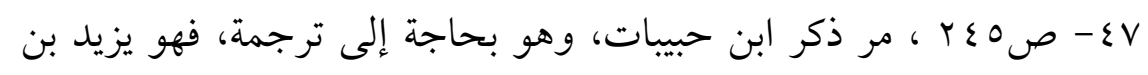

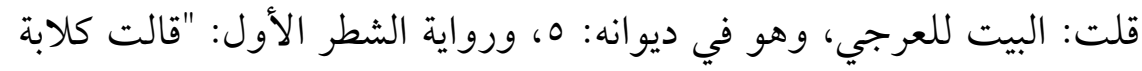

$$
\text { من هذا؟ فقلت لها". }
$$

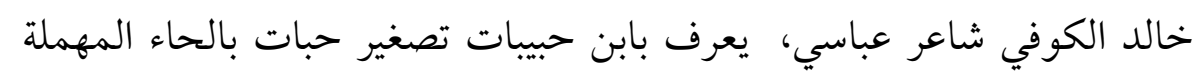

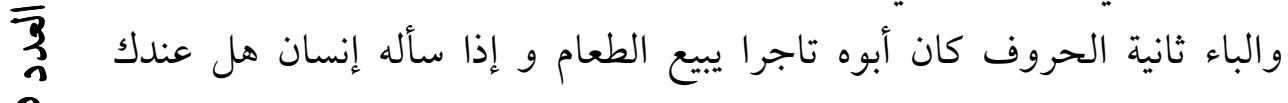

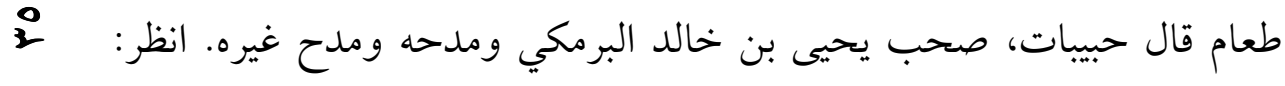

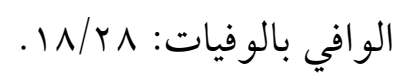

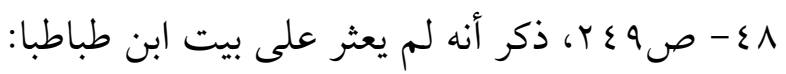

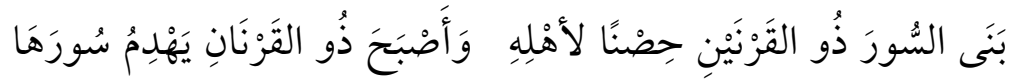

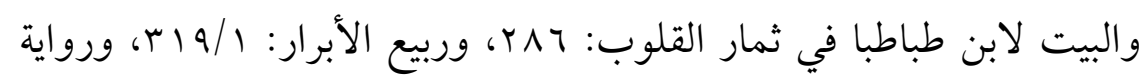

$$
\begin{aligned}
& \text { الشطر الأول فيهما: "وقد كان ذو القرنين يبنى مدينة". }
\end{aligned}
$$

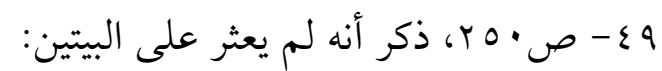

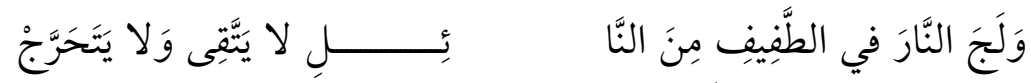

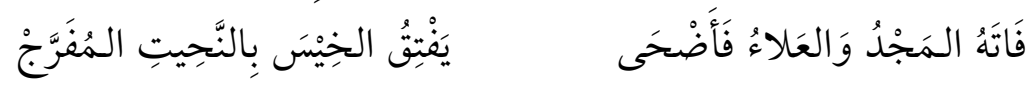


قلت: البيت الثاني من غير عزو في تهذيب اللغة: 11/7 ع، واللسان "فرج".

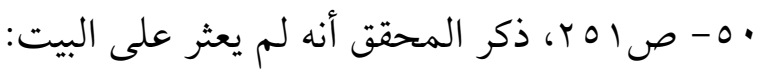

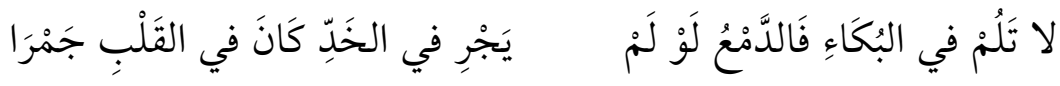

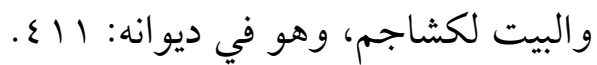

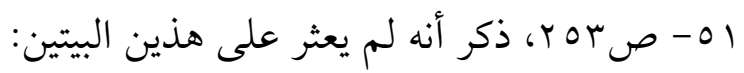

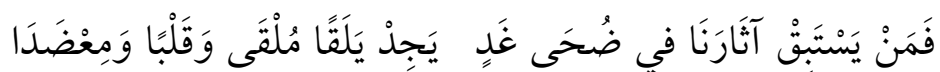

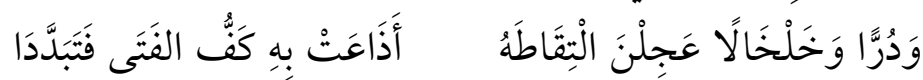

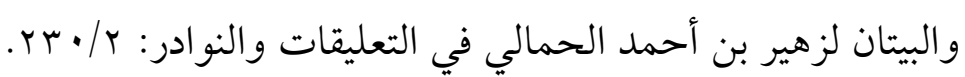
ror

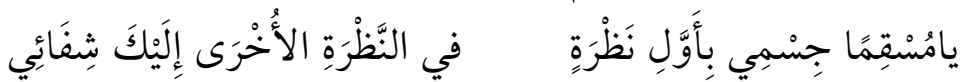
قلت: البيت في التيان: r/ •بس، وذكر مؤلفه أن ابن وكيع نسبه لخالد الكاتب، ولم أجده في المنصف، ولا في في ديوان خالد الكاتب، ومن غير عزو

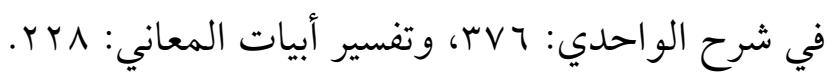
rه - ص آץ، قال في تخريج بيت رؤبة:

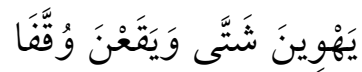

"لم أعثر عليه، وللعجاج والد رؤبة أرجوزة طويلة على هذا الروي ليس ويس ولئ

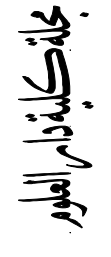
หฯ1

قلت: البيت على هذه الرواية لرؤبة في الأغاني: ·ـ/عهب، وعلى رواية "ويقعن وفقا" في ديوانه: · 11 .

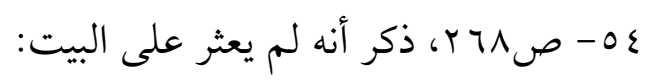

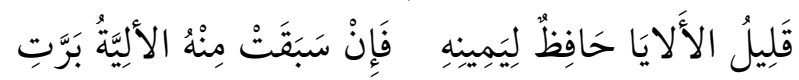
والبيت لكثير، وهو في ديوانه: Or Or، من قصيدة يرثي بها عبدالعزيز بن

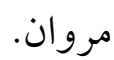

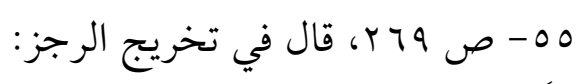

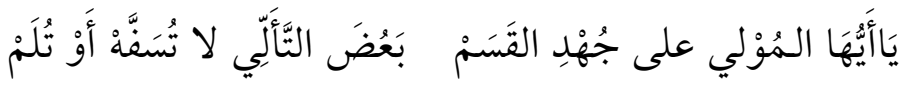




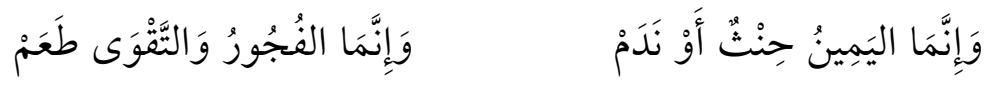

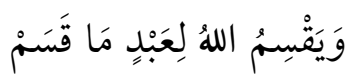

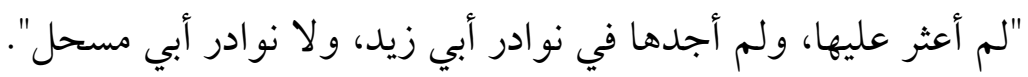

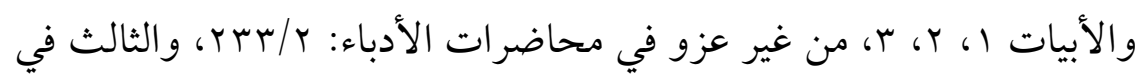

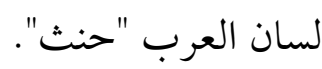

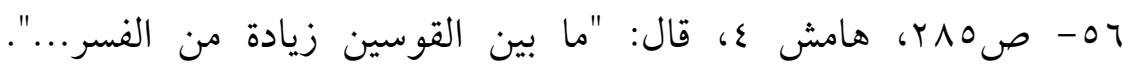

$$
\begin{aligned}
& \text { والصحيح أن العبارة موجودة في أحد الأصلين اللذَيْن اعتمد عليهما المحقق، } \\
& \text { وهي في طبعة الدجيلي: م •r. }
\end{aligned}
$$

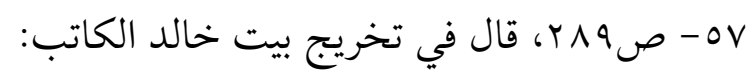

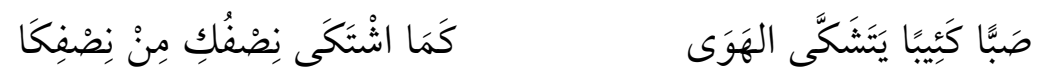

$$
\begin{aligned}
& \frac{\sqrt{3}}{3} \\
& \text { r.9 }
\end{aligned}
$$

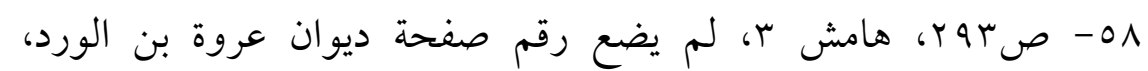

$$
\begin{aligned}
& \text { والبيت في ديوان خالد الكاتب: بr بr، وروايته: }
\end{aligned}
$$

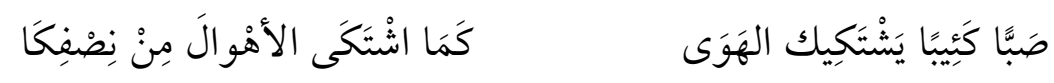

$$
\begin{aligned}
& \begin{array}{l}
\overline{3} \\
3 \\
0
\end{array} \\
& \text { ورقمها: } 79 . \\
& \text { ه० - ص V • r، ذكر أنه لم يعثر على البيت: }
\end{aligned}
$$

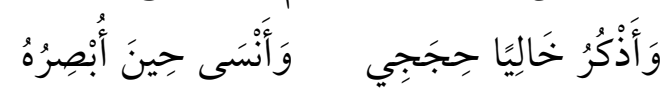

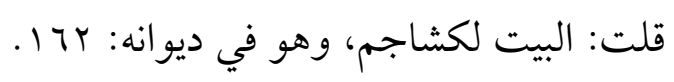

\section{الخاتثة}




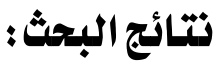

من خلال عملي في هذا البحث توصلت إلى نتائج من أهمها:

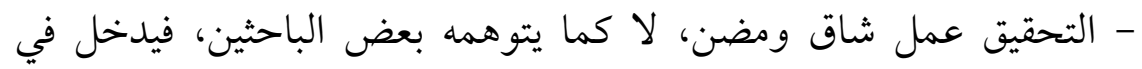

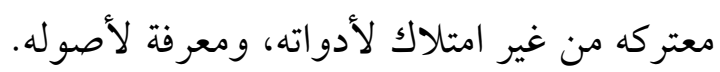

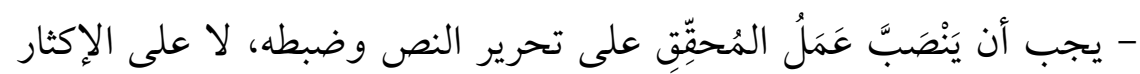
من الهوامش التى لا فائدة منها. - لم يحظ كتاب الفتح على أبي الفتح لابن فورجة بالعناية اللازمة، والتحقيق الجيد، على الرغم من تحقيقه من قبل ثلاثة محققين!، فلا يزال

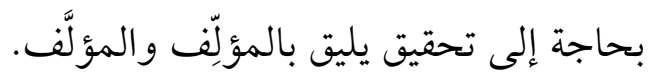

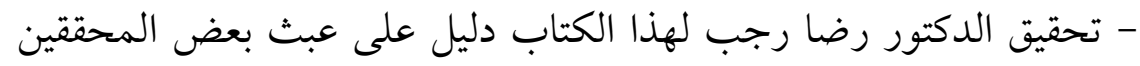

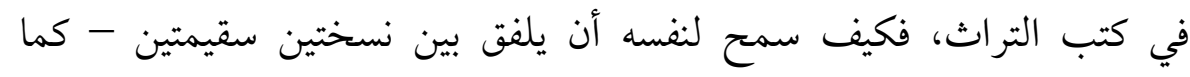

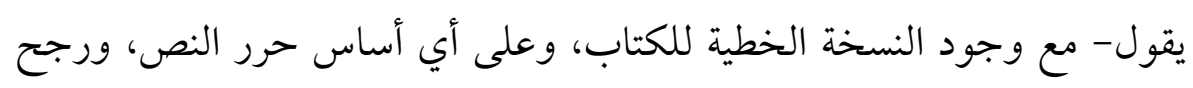
ما في نسخة على ما في الأخرى. - عدم أمانة المحقق العلمية، فقد غي الاخرى في في بعض أبيات المتببي من تلقاء

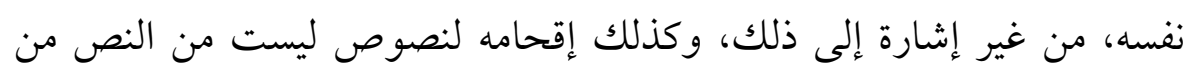
غير أن يشير إليها. وصلى الله على نبينا محمد وعلى آله وصحبه أجمعين.

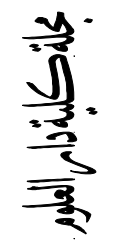
rV. 率

\section{المصادروالمراجع}

(Y) (أبو العتاهية أشعاره وأخباره. تحقيق د/شكري فيصل. دار الملاح. دمشق. د.ت.

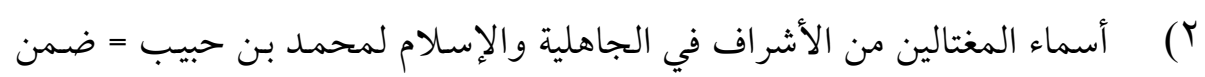

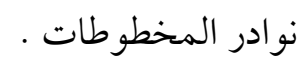

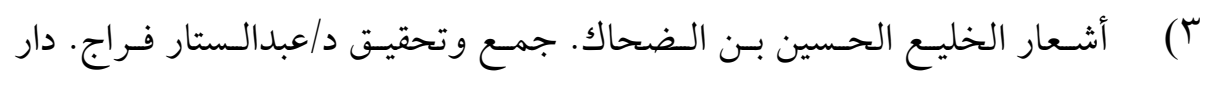

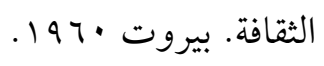

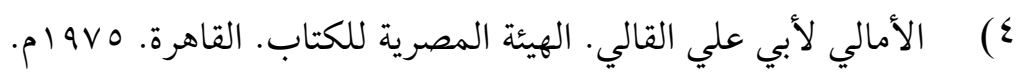


0) أمية بـن أبي الصلت حياته وشعره ـ تحقيق بهجة عبد الغفور الحديثي .وزارة

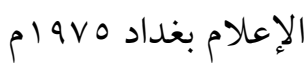

7) بهجــة المجـالس وأنسس المجـالس وشـحذ الـذاهن والهـاجس. لابسن عبـدالبر القرطبي. تحقيق محمد مرسي الخولي. دار الكتب العلمية. بيروت. د.ت.

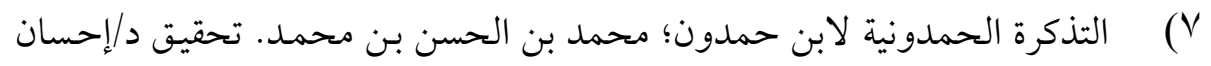

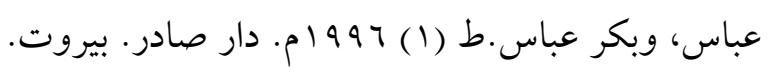

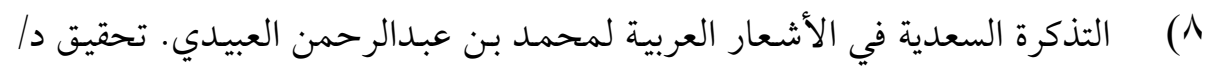

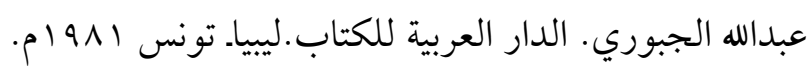

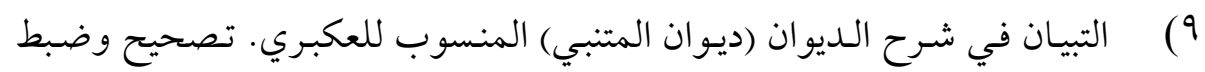
مصطفى السقا وآخرين. نشر مكتبة الرياض الحديثة. الرياض لد.ت إن.

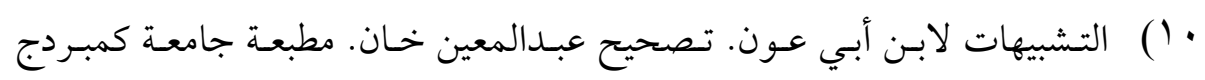

التعليقات والنوادر لأبي علي الهجري. تحقيق د/حمود عبدالأمير الحمادي. دار

r ( ) تفسير أبيات المعاني من شعر أبي الطيب المتنبي. لأبي المرشد المعري تحقيق

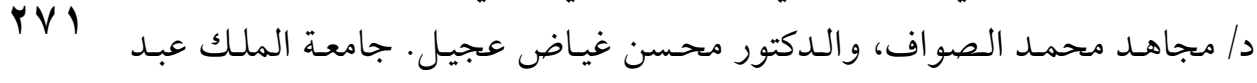

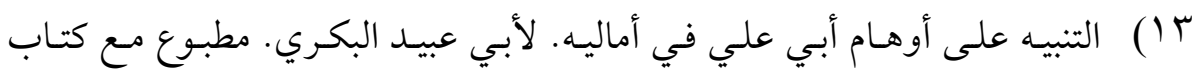
الأمالي للقالي.

ع ( ) تهذيب اللغة للأزهـري. تحقيق جماعة مـن العلماء. المؤسسة المصرية العامة للتأليف عیr آهـ

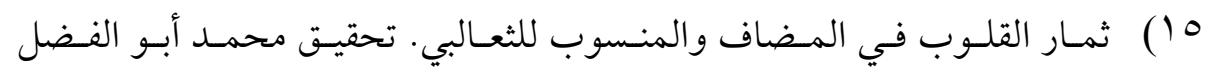
إبراهيم. دار المعارف بمصر 910 19.

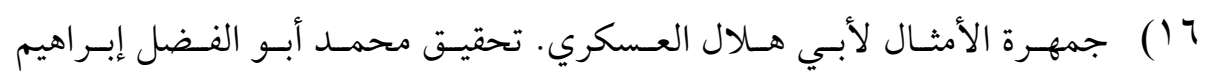

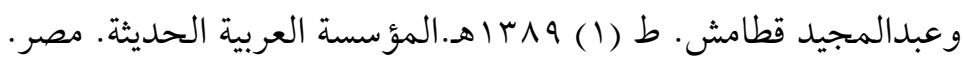


(IV ) الحماسـة لأبي تمام تحقيق د/عبد الله عبد الرحيم عسيلان. مطبوعـات جامعـة (1)

الإمام محمد بن سعود الإسلامية بالرياض الم الـ الهـ.

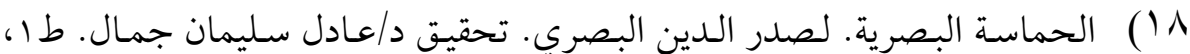
• ب أهـ مكتبة الخانجي. القاهرة.

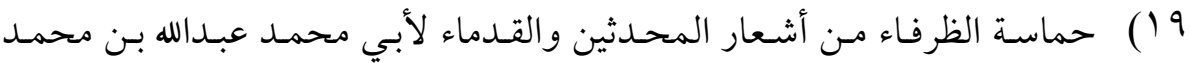

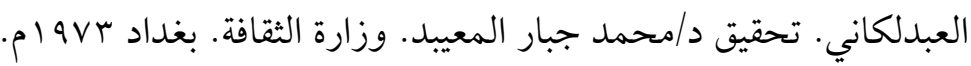

• .

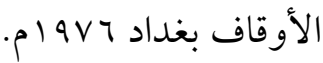

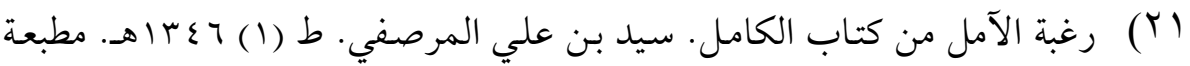
النهضة. مصر.

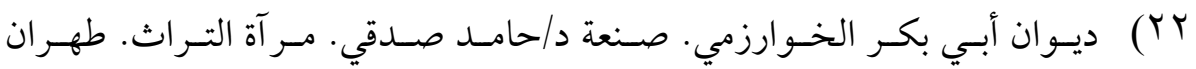

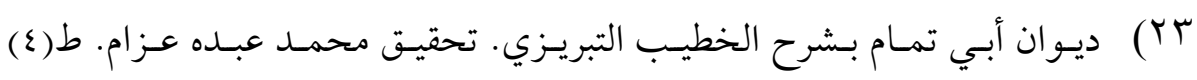
r r 191 ام. دار المعارف مصر.

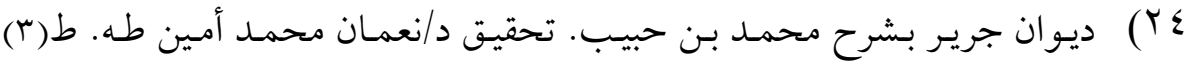

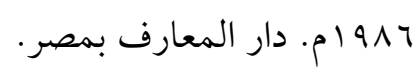

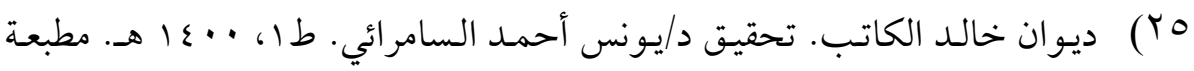
الرسالة. بغداد.

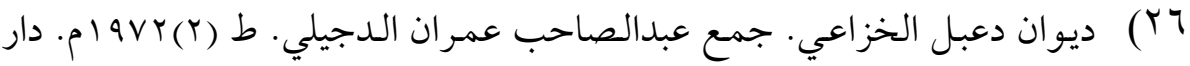

$$
\text { الكتاب اللبناني. بيروت. (مئ. }
$$

(YV

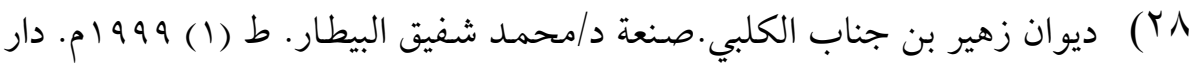

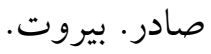

9 Y ) ديوان أبي الطيب المتنبي. تحقيق د/عبدالوهاب عزام. لجنة التأليف والترجمة

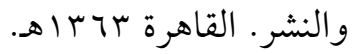

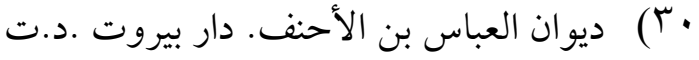


ديوان أبي العتاهية = أبو العتاهية أشعاره وأخباره.

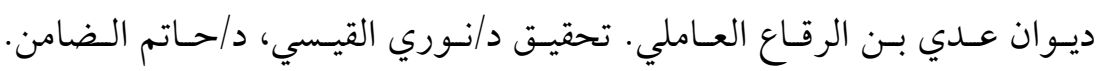

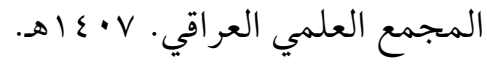

سT) ديوان عدي بن زيد العبادي. حققه وجمعه محمد جبار المعيبد. وزارة الثقافة. بغداد 970 19 م.

ع ب) ديوان العرجي رواية أبي الفتح بن جني. تحقيق خضر الطائي، ورشيد العبيدي. ط (1) (1) ا هـ. الشركة الإسلامية للطباعة. بغداد.

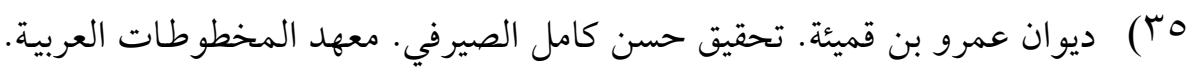

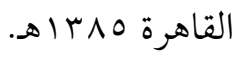

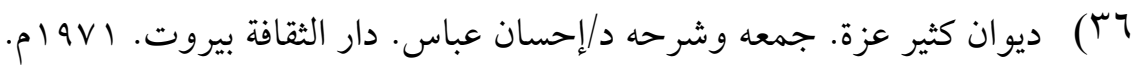

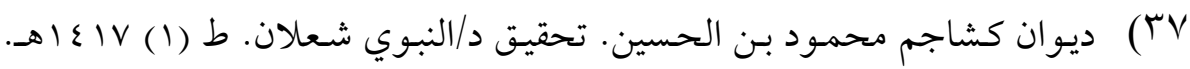

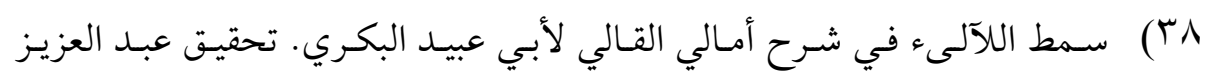
الميمني. ط(r) ع • ع أهـ. دار الحديث. بيروت.

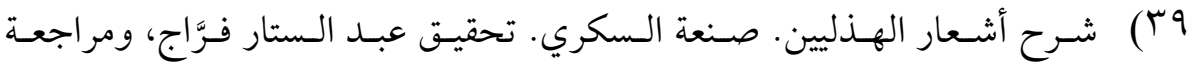

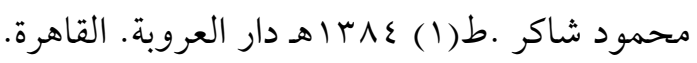

$\overline{3}$

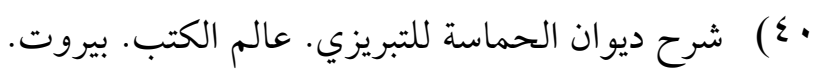

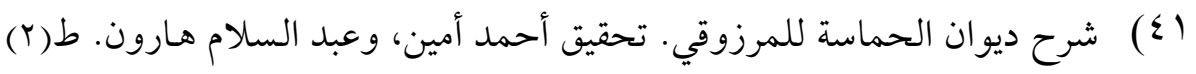

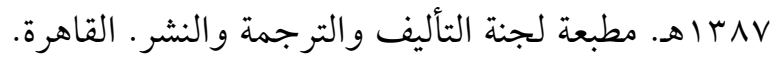

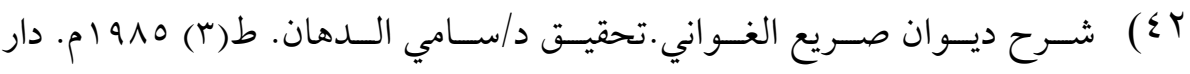
المعارف. مصر. بـ ) شرح ديوان أبي الطيب المتنبي "معجز أحمد" المنسوب إلى أبي العلاء المعري.

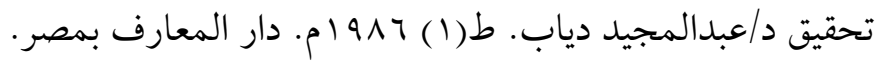

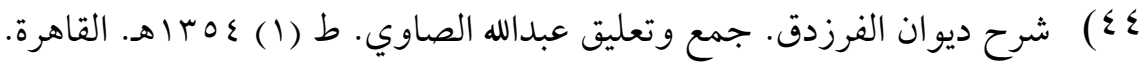

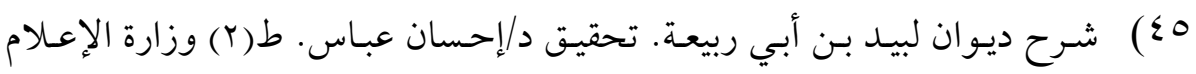
الكويت ع 9 ام. 
شرح ديوان المتنبي للواحدي. تحقيق فريدريخ ديتريصي. دار الكتاب الإسلامي.

(§V ) شرح مشكلات ديوان شعر أبي الطيب المتنب. (الفتح على أبي الفتح). لابن فورجة. مخطوطة في مكتبة الأوسكريال تحت رقم V•r لr.

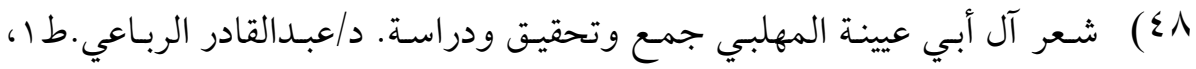
ع ع أهـ. أمانة عمان الكبرى. الأردن.

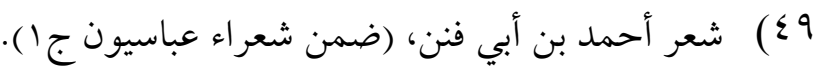

$$
\begin{aligned}
& \text { •0) شعر الخليل بن أحمد. (ضمن شعراء مقلون). }
\end{aligned}
$$

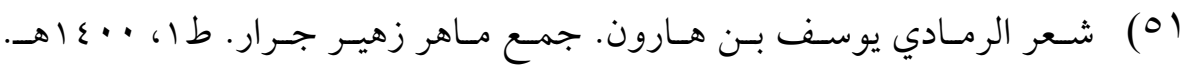

$$
\text { المؤسسة العربية للدراسات والنشر · بيروت. }
$$

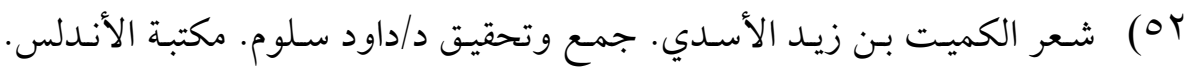
• .01979

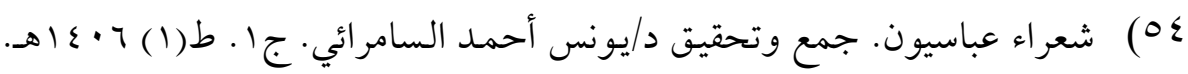
عالم الكتب، ومكتبة النهضة العربية.بيروت.

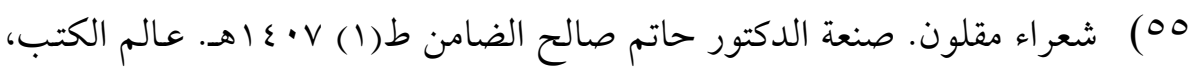
ومكتبة النهضة العربية. بيروت. لبنان.

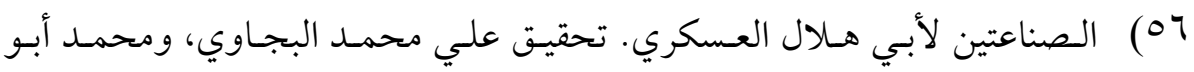

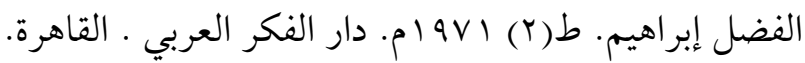

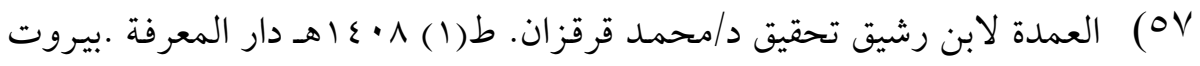
لبنان.

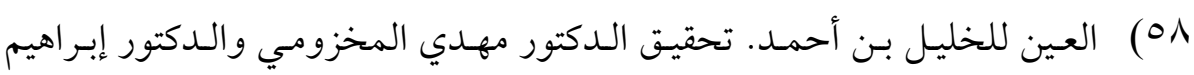

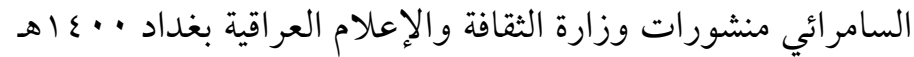

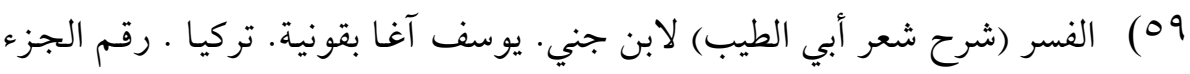

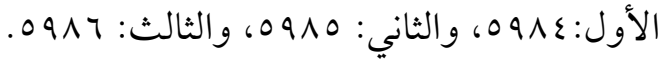




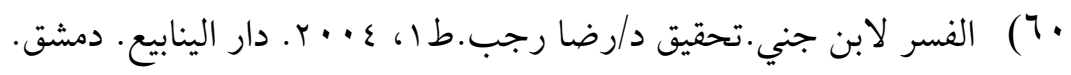

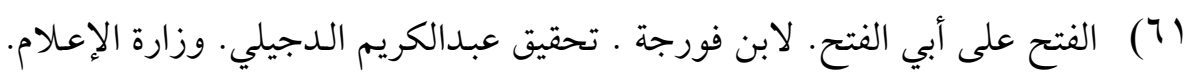

$$
\begin{aligned}
& \text { بغداد } 9 V \text { ا م. } \\
& \text { rT7) الفتح على أبي الفتح لابـن فورجـة. تحقيـق د/محسن غيـاض. مجلـة المـورد. }
\end{aligned}
$$

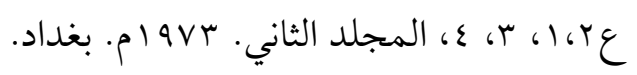

با7) لباب الآداب للثعالبي. تحقيق داقحطان رشيد صالح.وزارة الثقافة والإعلام.

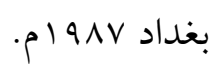

$$
\text { צ T) لسان العرب لابن منظور. دار المعارف بمصر . د.ت. }
$$

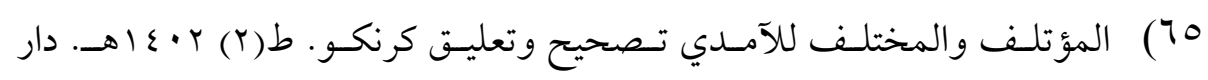

$$
\text { الكتب العلمية. بيروت لبنان. }
$$

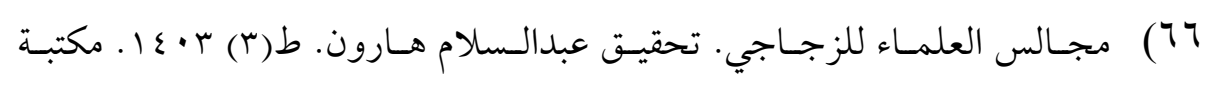

$\frac{\sqrt{3}}{3}$

$$
\text { الخانجي بالقاهرة، ودار الرفاعي بالرياض. }
$$

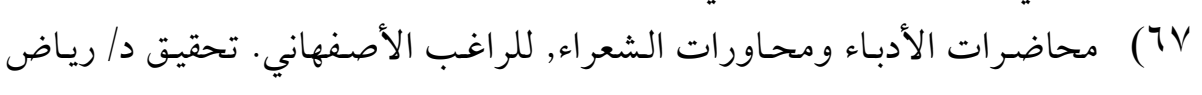

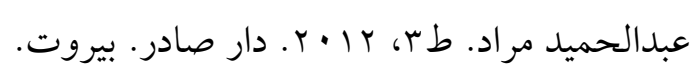

$$
\text { 14 آ7 المخصص لابن سيدة. دار الكتاب الإسلامي. القاهرة. }
$$

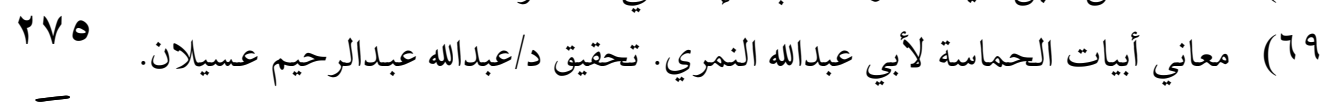

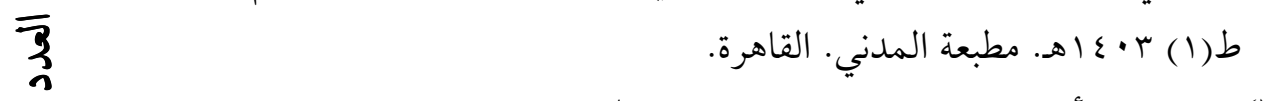

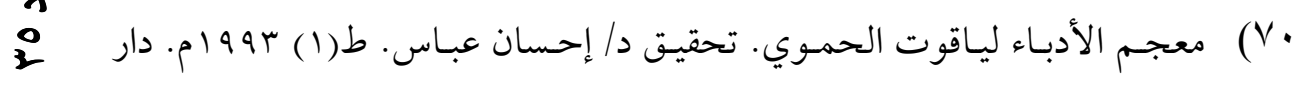

$$
\text { الغرب الإسلامي. بيروت. }
$$

(V) (VY

$$
\text { القاهرة. }
$$

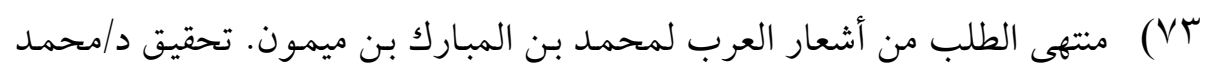

$$
\text { نبيل طريفي. ط(1) } 999 \text { ام. دار صادر. بيروت. }
$$

(V乏

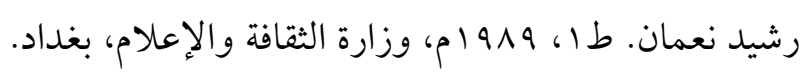




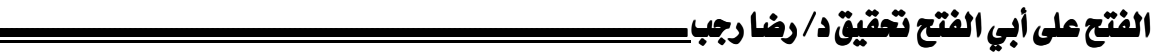

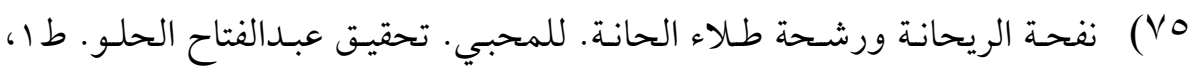
NAv

(VT نوادر المخطوطات. تحقيق عبدالسلام هارون .ط(r) rar I اهـ. مطبعة مصطفى

$$
\text { البابي الحلبي. القاهرة. }
$$

(VV

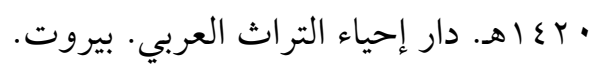

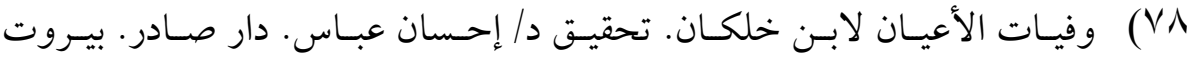

$$
.01971
$$

\section{الهوام والإحالات}

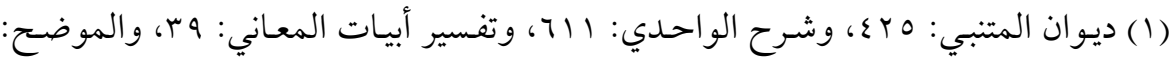

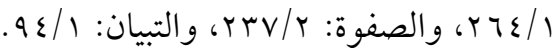

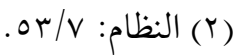

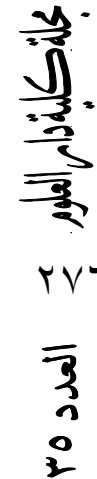

3
3 